\title{
THE GEOCHEMICAL ATLAS OF EUROPEAN GROUND WATER WITH EMPHASIS ON HELLAS
}

\author{
Demetriades A. ${ }^{1}$, Reimann C. $^{2}$, Birke M. ${ }^{3}$ and the EGG Team ${ }^{4}$ \\ 'Institute of Geology and Mineral Exploration, Spirou Louis 1, Entrance C, Olympic Village, 13677 \\ Acharnae, Athens, Hellas.Tel.: (+30) 213 1337272; E-mail: ademetriades@igme.gr \\ ${ }^{2}$ Geological Survey of Norway, 7491 Trondheim, Norway \\ ${ }^{3}$ Federal Institute for Geosciences and Natural Resources, Wilhelmstrasse 25-30, \\ Branch Office Berlin, 13593, Berlin, Germany \\ ${ }^{4}$ EuroGeoSurveys, 36-38, Rue Joseph II, 1000 Brussels, Belgium
}

\begin{abstract}
A first impression of the geochemistry and quality of European ground water was obtained by using bottled mineral water as a sampling medium. In total, 1785 bottled waters were purchased from supermarkets of forty European countries, representing 1247 wells/drill holes/springs at 884 locations. All bottled waters were analysed for 72 parameters at the laboratories of the Federal Institute for Geosciences and Natural Resources (BGR) in Germany.

The European geochemical maps give a first impression of the natural variation in ground water at the continental scale. The majority of European bottled waters are classified as of $\mathrm{Ca}-\mathrm{HCO}_{3}$ type, because of the widespread carbonate lithologies, but there is considerable variation from $\mathrm{Na}-\mathrm{HCO}_{3}$ type related to granitic rocks to $\mathrm{Na}-\mathrm{Cl}$ type associated with deep saline brines. Since, the dominating lithology in Hellas comprises limestone, dolomitic limestone, marble, and mafic-ultramafic rocks (ophiolites), the dominant major ions in Hellenic bottled waters are $\mathrm{Ca}^{2}+, \mathrm{Mg}^{2}+, \mathrm{CO}_{3}{ }^{2-}$ and $\mathrm{HCO}_{3}$, and are, thus, classified in the $\mathrm{Ca}^{2}+-\mathrm{Mg}^{2}+-\mathrm{HCO}_{3}$ - hydrochemical facies. The source aquifers of Hellenic bottled water are apparently continuously replenished by fresh water.

Chromium, $\mathrm{V}$ and $\mathrm{U}$ are discussed, because of their importance in Hellenic ground water. In Europe, the former is clearly related to ophiolites, whereas $\mathrm{V}$ indicates the presence of recent volcanism and basaltic rocks, and $U$ is associated with granitic intrusions and Bunter (central England) and Keuper (central Europe) sandstone of early and late Triassic, respectively. It can, therefore, be concluded that geology is one of the key factors influencing the observed element concentrations for a significant number of elements.
\end{abstract}

Keywords: Ground water geochemistry, bottled water, ionic ratios, hydrochemical classification, Europe, Hellas








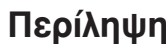

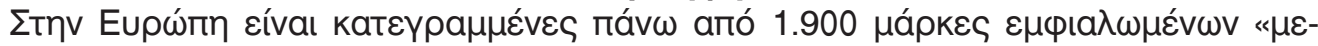

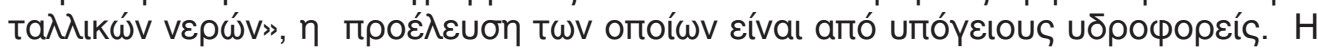



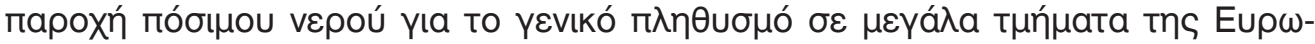

















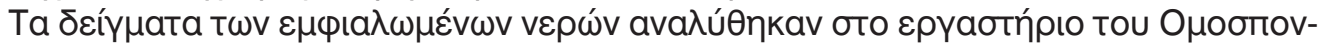




$\mathrm{Ca}, \mathrm{Ce}, \mathrm{Co}, \mathrm{Cr}$, Cs, Cu, Er, Eu, Fe, Ga, Gd, Ge, Hf, Hg, Ho, I, K, La, Li, Lu, Mg, Mn, $\mathrm{Mo}, \mathrm{Na}, \mathrm{Nb}, \mathrm{Nd}, \mathrm{Ni}, \mathrm{Pb}, \mathrm{Pr}, \mathrm{Rb}$, Sb, Sc, Se, Sm, Sn, Sr, Ta, Tb, Te, Th, Ti, Tl, Tm, U, V, W, Y, Yb, Zn, Zr, (ii) $\mu \varepsilon$ ICP-AES үıа Ba, Ca, K, Mg, Mn, Na, Sr, P, Si, (iii) $\mu \varepsilon$ IC үıа



































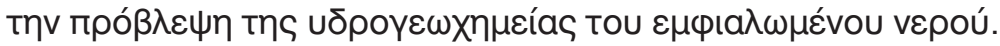

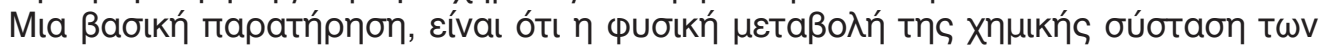

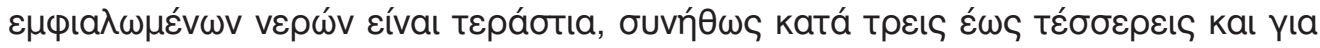

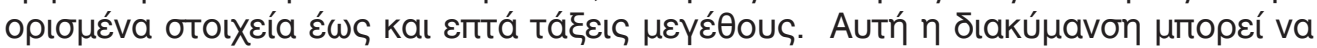

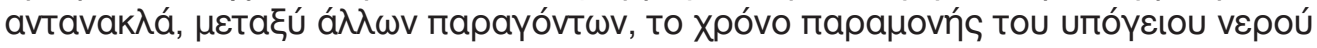





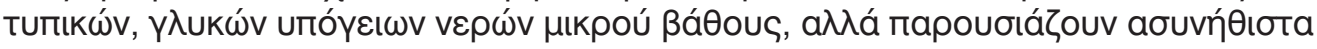



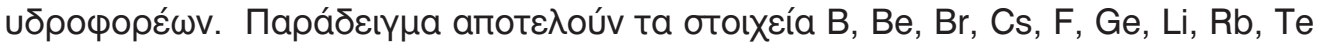




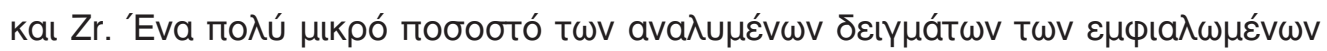



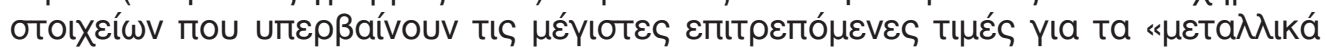




















artno/001201002

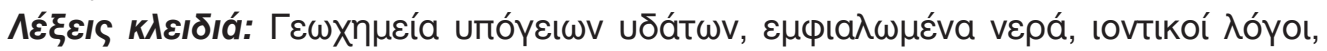



\section{Introduction}

The EuroGeoSurveys Geochemistry Expert Group is dedicated to provide high quality databases on the geochemistry of earth materials with which humans are in direct contact with to decision makers, geoscientists, researchers and the public alike.

The Geochemical Atlas of Europe provided the first harmonised pan-European multi-determinand databases on residual soil (top- and sub-soil), humus, stream and floodplain sediments, and stream water (Salminen et al., 2005, De Vos et al., 2006). Ground water, although very important was, however, missing from this database. The main reason is that to collect systematically representative ground water samples at the European scale is not an easy task, and may be prohibitively expensive if performed at a high sample density.

It was against this background that the EuroGeoSurveys Geochemistry Expert Group put forward a novel idea that "ground water" samples can be readily bought from supermarkets throughout Europe as bottled mineral water, and used as a first proxy for ground water geochemistry and quality at the European scale. Though the idea was met with some scepticism to begin with, it was finally decided that it was worth testing, because it provided a cost-effective approach. The results of this project are presented in a geochemical atlas (Reimann and Birke, 2010), and in a special issue of the Journal of Geochemical Exploration (Birke et al., 2010a), as well as in other publications (Birke et al., 2010b, Reimann et al., 2010a, b; De Vivo et al., 2010; Lima et al., 2010 - see below).

Hellas is a country with a diverse geology and climate. There are areas blessed with water and others that are not (Kanellopoulou, 2002; Maheras, 2004; Mimikou, 2005; Hatzianastassiou, 2008; Livada, 2008). Climatic change is, in fact, affecting Hellas to a variable degree. This has been observed quite evidently in the bottled water industry, where natural spring water is used for bottling. Up to now two bottling companies have closed down, the first in Thrace in north-east Hellas, and the second in south Peloponnese. 
The reason in both cases was the reduced capacity of the natural spring. It is here very relevant to quote Benjamin Franklin (1706-1790) "We will only know the worth of water when the well is dry". However, ground water resources are still available in areas of Hellas with a comparatively high rainfall, especially in western part of Hellas, and western and central Crete (>1800 mm; Vassiliades, 2010). Hence, because of the increase demand for bottled water, new companies have started operations in these areas.

The length of the Hellenic coastline is $13,780 \mathrm{~km}$, and most of it is due to the 6,000 islands and islets. Many of the inhabited islands do not have good quality potable water supply, and the islanders rely on bottled water for drinking and cooking, e.g., Aegina, some of the Cyclades and Dodecanese Islands, Zakinthos, an Ionian Sea island, etc. There are also some areas on mainland Hellas that resort to bottled water, because of the poor quality of their ground water resources, e.g., Argholidha (north-east Peloponnese) and Thessaly (eastern central Hellas), because of high nitrates, and some parts of Elia Prefecture (north-west Peloponnese) due to elevated concentrations of iron and manganese.

The consumption of bottled water in Hellas was 380 million litres in 1998, it reached 627 million litres in 2003, and in 2005 was up to 1 billion litres. It appears that the consumption of bottled water increases by about $10-12 \%$ per year. On average, the consumption was 45 litres/person in 1998 and by 2009 it reached over 100 litres/person. The greatest consumption is, of course, during the summer period with the influx of hundreds of thousands of tourists.
To set up a bottled water industry a permit is required from the Health Department of the Prefecture for table water, whereas for mineral water from the Ministry of Health. Hence, the difficulty of finding out all bottled water brands available on the Hellenic market, since some of them are very local. The Mineral Water Organisation lists 31 Hellenic brands (http://www.mineralwaters. org/). Whereas, in accordance with Article 1 of Directive 2009/54/EC of the European Parliament and of the Council of 18 June 2009 on "the exploitation and marketing of natural mineral waters" (EU, 2009), there are only 38 natural mineral waters recognised officially by Hellas (Tab. 1). Nevertheless, there are more brands on the market, and a conservative estimate is about 65 bottled water companies are operating in different parts of the country.

It is stressed at the outset that it was never the intention of this project to assess the quality of bottled water, since for such an assessment many more parameters should have been analysed, and specifically organic compounds and microbiological components (refer to Fotiou and Kolovos, 2004). Also, a separation of Natural Mineral Water from Natural Bottled Drinking Water (often called Table Water) should have been made, because each has to comply with a different legislation, i.e., EU Directive 2003/40/EC (EU 2003) and EU Directive 1998/83/EC (EU 1998), respectively. However, since readers may be interested in the quality of Hellenic bottled water, it can be safely stated that the concentrations of determined inorganic parameters are below the recommended statutory guideline values. The analytical data of this study are included on the CD-rom accompanying the atlas of the "Geochemistry of European Bottled Water" (Reimann and Birke, 2010). 


\section{Geotronic Zones of Hellas}

The lithology of Hellas is comprised from sediments and igneous rocks of Tethys that are grouped into geotectonic zones, consisting of rocks which have a similar development, and representing a unified geomorphological entity (Fig. 1); the Tethyan mafic-ultramafic ophiolitic rocks, and other intrusive-extrusive igneous rocks, as well as the Upper Tertiary intermontane molasse deposits are presented as different entities on the map. The Rhodope Massif is an exception, because it did exist before the opening of the Tethys Sea, and palaeogeographically belongs to the European craton. Almost all geotectonic zones end with flysch, which consists of a rhythmic sequence of sandstone, marl, clay, and more rarely conglomerate or limestone. The general features of the geotectonic zones of Hellas are concisely described in Tab. 2, together with the bottled water samples falling in each zone, and Fig. 1 shows their geographical distribution and location of bottled water industries of Tab. 1. Tertiary and Recent sediments are not presented on Fig. 1.

\begin{tabular}{|c|c|c|c|}
\hline \begin{tabular}{l|} 
Sample \\
Number
\end{tabular} & Brand name & Name of spring/borehole & Bottling location \\
\hline 1 & Vikos* & Vikos & Fteri Perivlepou Ioannina Prefecture \\
\hline 2 & Zagori* & Zagori & Kranoula, Ioannina Prefecture \\
\hline 3 & Korpi* & Korpi & Korpi, Monastiraki, Akarnanika Mts, Vonitsa, Aetoloakarnanias Pref. \\
\hline 4 & Ioli* & Ioli & Moschochori, Fthiotida Prefecture \\
\hline 5 & Sariza & Sariza & Apikia, Andros Island, Cycladhes Prefecture \\
\hline 6 & Avra $^{*}$ & Avra, Aegion & Dimos Aegiou, Achaia Prefecture \\
\hline 7 & Aqua Vita & Aghia Varvara, Rhodes I. & Aghia Varvara, Rhodes I., Dodekanissos Prefecture \\
\hline 8 & Pindos & Ziaka Grevena & Grevena, Grevena Prefecture \\
\hline 9 & Samarina* & Goura Samarinas & Samarina, Grevena Prefecture \\
\hline 10 & Drosoula & Roditi & Roditi Spring, Kozani, Kozani Prefecture \\
\hline 11 & Nera kritis & Foot of White Mountains & Varipetro Therisso Chania, Crete I., Chania Prefecture \\
\hline 12 & Mythical & Psiloritis & Psiloritis, Crete I., Heraklion Prefecture \\
\hline 13 & Rouva's & Gergeri, foot of Mt. Psiloritis & Gergeri, Heraklion, Crete I., Heraklion Prefecture \\
\hline 14 & Samaria & Stylos & Stylos, Foot of White Mountains, Crete I., Chania Prefecture \\
\hline 15 & Lyttos & Chomoprina, Malia Municipality & Cocal Cola 3E, VIPE, Iraklion, Crete I., Chania Prefecture \\
\hline 16 & Gortys & Asterousia Mountains, Aghia Marina & Lendas, Crete I., Heraklion Prefecture \\
\hline 17 & Zaro's* & Amati, Psiloritis Mt. & Heraklion, Crete I., Heraklion Prefecture \\
\hline 18 & Rizitiko & Psiloritis & Heraklion, Crete I., Heraklion Prefecture \\
\hline 19 & Krini & Dikti Mountains, Crete & Kasteli, Pediados, Heraklion Prefecture \\
\hline 20 & Dikti & Baboulani, Dikti (Lasithi) & Crete I., Lasithi Prefecture \\
\hline 21 & Kimi ${ }^{*}$ & Honeft tiko (Kimi) & Honeftiko, Kimi, Euboca I., Euboea Prefecture \\
\hline 22 & $\begin{array}{l}\text { Eviva (Gargaro, Mitsikeli, } \\
\text { Marata, Physiko Nero AB) }\end{array}$ & Sepeta & Kalpaki, Ioannina Prefecture \\
\hline 26 & Loutraki* & Loutraki & Loutraki, Korinthias Prefecture \\
\hline 27 & Loutraki Hydria & Loutraki & Loutraki (Hydria), Korinthias Prefecture \\
\hline 28 & Loutraki Karadanis Provis & Loutraki & Loutraki, Korinthias Prefecture \\
\hline 29 & Loutraki ivi & Gerania Mountains & Loutraki, Korinthias Prefecture \\
\hline 30 & Iris Loutraki & Loutraki & Loutraki, Korinthias Prefecture \\
\hline 31 & Ydor Sourotis** & Anthemia (Anthemounda Basin) & Souroti, Thessaloniki Prefecture \\
\hline 33 & Athos (Iro) & S. Platani (Poligiros) & Akonorachi, Poligiros, Chalkidhiki Prefecture \\
\hline 34 & Evdoro* & Evdoro & Evdoro, D.D. Mexiatae, Municipality of Ypati, Fthiodidhas Prefecture \\
\hline 35 & Tzoumerka & Agathi Melissourgon & Melissourgoi, Arta Prefecture \\
\hline 36 & Velouhi & Kefalovrisso Aghia Triada & Velouhi, Evritania Prefecture \\
\hline 37 & Seli* & Assos, Vermion & Spilia, Vermion Mountain, Kozani Prefecture \\
\hline 38 & Pigi Paikou & Axioupoulis & Axioupolis, Paiko Mountains, Kilkis Prefecture \\
\hline 39 & Krinos* & Anastassopoulou spring & Rododafni Aegio, Achaia Prefecture \\
\hline 40 & Zefiros & Zefiros, Achaia Mountains & Chondrolongos, Rio Municipality, Achaia Prefecture \\
\hline 45 & Hyas* (Krinea) & Kaliani & Kaliani, Korinthia Prefecture \\
\hline 46 & Beles (Aqua) & Angistro & Angistro, Serres Prefecture \\
\hline 47 & Klinos* & Palavi & Kinotita Klinou, Pindos Mountains, Trikalla Prefecture \\
\hline 48 & Vitsi & Florina springs & Florina, Florina Prefecture \\
\hline 49 & Drossia & Drossia & Mt. Kaimaksalan, Imathia Prefecture \\
\hline
\end{tabular}

Tab. 1. Hellenic bottled waters analysed in this study. The star $\left(^{*}\right)$ denotes natural bottled mineral water listed in Directive 2009/54/EC (EU, 2009). The others are classified as Table water. In brackets are given bottled waters from the same location, but marketed under a different brand name (see Fig. 1 for their location)

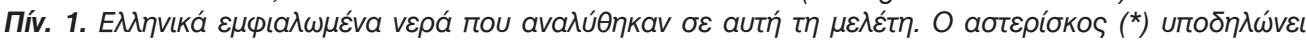

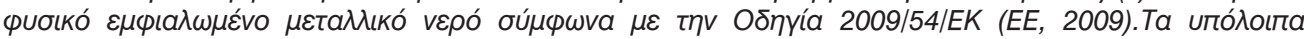

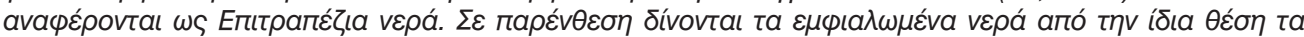

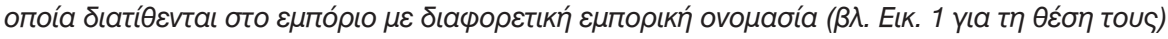




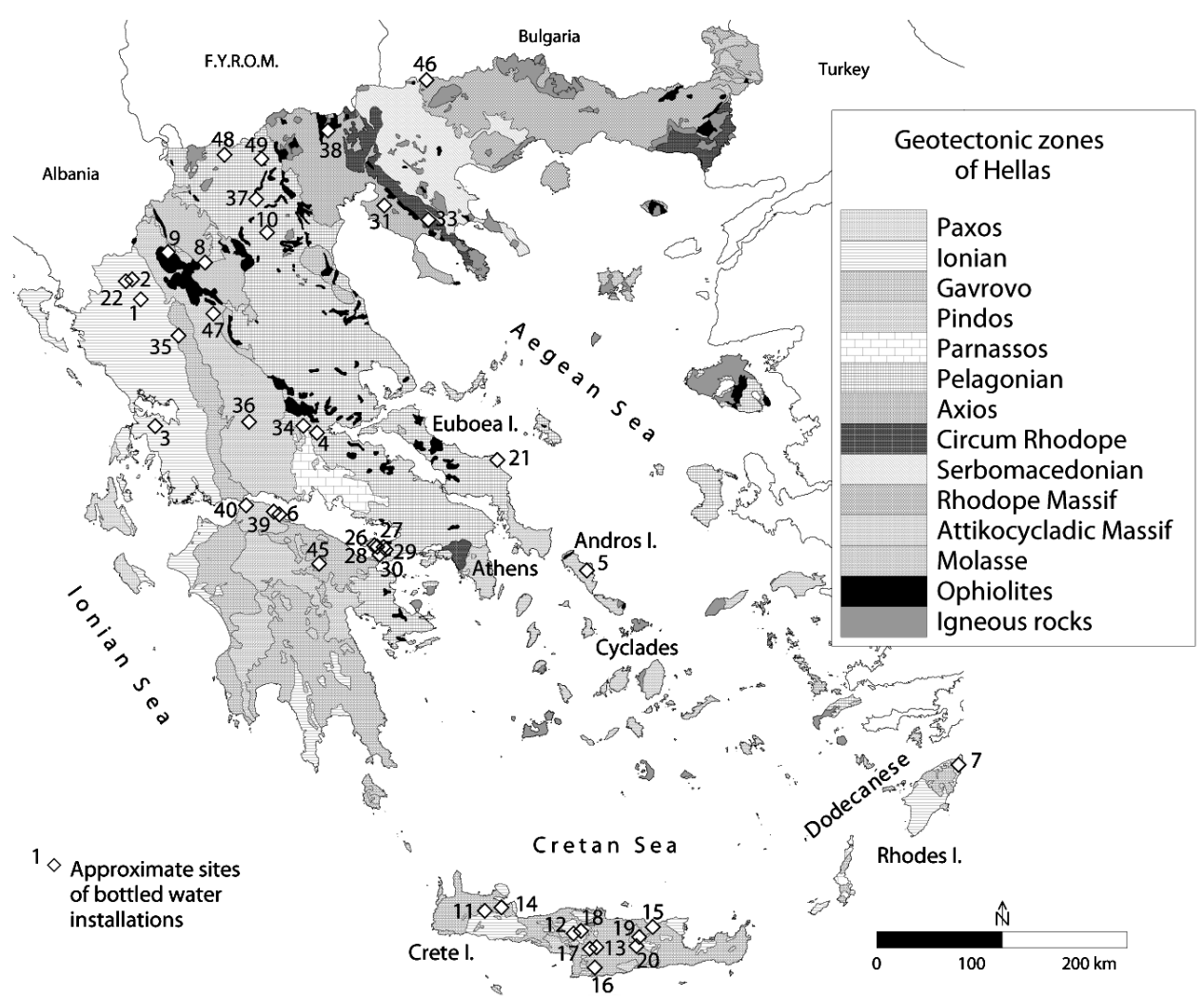

Fig. 1. Geotectonic zones of Hellas and the approximate sites of bottled water installations (geotectonic zones modified from Bornovas and Rondogianni-Tsiambaou, 1983. Layers digitised by E. Vassiliades, Institute of Geology and Mineral Exploration, Division of Geochemistry and Environment).

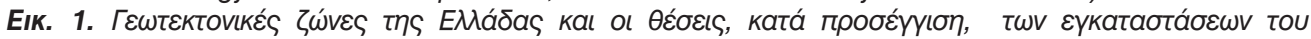

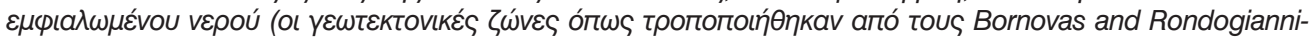

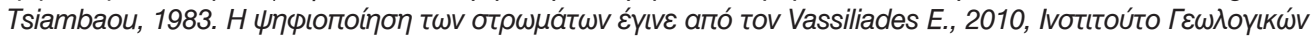

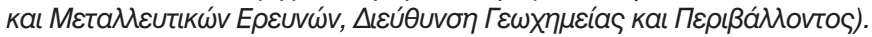

\section{Materials and Methods}

\subsection{Sampling}

Instructions were sent to all members of the EuroGeoSurveys Geochemistry Expert Group, as well as to friends and colleagues travelling to European countries, to purchase from supermarkets as many different bottled mineral water brands as possible. In case the same bottled water was available with and without gas, both varieties were purchased. If bottled water was marketed in different bottle types (e.g., glass and PET), or in bottles of different colour all varieties were bought whenever possi- ble. The sampling period started in November 2007 and ended in April 2008. The total number of bottles purchased in Europe, and subsequently analysed, was 1785 from 884 locations. Whereas, in Hellas a total of 61 still bottled waters were purchased from supermarkets, representing 41 different locations (Tabs 1 and 2, Fig. 1); 57 bottled waters were in soft polyethylene terephthalate (PET) and four in clear glass bottles; eight PET bottles were duplicates, purchased from different Hellenic supermarkets, and another eight were from the same location, but marketed under a different brand 
name. Apart from the duplicate bottles that were used for quality control purposes, three different brands of water for injection were purchased, and used as blanks.

All bottled water samples were sent to the Federal Institute for Geosciences and Natural Resources (BGR) in Germany, where they were kept refrigerated until their analysis. Before shipping, the analytical results recorded on bottle labels were transferred to an Excel worksheet together with other pertinent information.

\subsection{Analysis}

The bottled water samples were analysed at the chemical laboratory of the Federal Institute for Geosciences and Natural Resources (BGR) in Berlin. Details of sample preparation and the extensive analytical programme are reported by Reimann and Birke (2010) and Birke et al. (2010b). Thus, only an outline of the analytical methods employed is provided below:

- Inductively coupled plasma atomic quadrupole mass spectrometry (ICPQMS): Ag, Al, As, B, Ba, Be, Bi, Cd, Ca, $\mathrm{Ce}, \mathrm{Co}, \mathrm{Cr}, \mathrm{Cs}, \mathrm{Cu}, \mathrm{Er}, \mathrm{Eu}, \mathrm{Fe}, \mathrm{Ga}, \mathrm{Gd}$, $\mathrm{Ge}, \mathrm{Hf}, \mathrm{Hg}, \mathrm{Ho}$, I, K, La, Li, Lu, Mg, Mn, $\mathrm{Mo}, \mathrm{Na}, \mathrm{Nb}, \mathrm{Nd}, \mathrm{Ni}, \mathrm{Pb}, \mathrm{Pr}, \mathrm{Rb}, \mathrm{Sb}, \mathrm{Sc}$, Se, Sm, Sn, Sr, Ta, Tb, Te, Th, Ti, TI, $\mathrm{Tm}, \mathrm{U}, \mathrm{V}, \mathrm{W}, \mathrm{Y}, \mathrm{Yb}, \mathrm{Zn}, \mathrm{Zr}$;

\begin{tabular}{|c|c|c|}
\hline Bottled water samples & Lithology & Mineralisation \\
\hline \multicolumn{3}{|c|}{ Paxos Zone (or Pro-Apulian Zone) } \\
\hline & $\begin{array}{l}\text { Gypsum, limestone and marl of Triassic to } \\
\text { Eocene, and flysch of Miocene age }\end{array}$ & gypsum \\
\hline \multicolumn{3}{|c|}{ Ionian Zone } \\
\hline $\begin{array}{l}\text { Vikos (1), Zagori (2), } \\
\text { Korpi (3), Aqua Vita } \\
\text { (7), Mythical (12), } \\
\text { Rizitiko (18), Eviva } \\
(22)\end{array}$ & $\begin{array}{l}\text { Evaporites (halite, gypsum, etc.), and red } \\
\text { pelagic limestone and shale of Triassic; thin } \\
\text { bedded pelagic limestone of Jurassic to lower } \\
\text { Cretaceous age; beige to reddish pelagic } \\
\text { limestone of Cretaceous to Eocene age, and } \\
\text { flysch of Eocene to Miocene age. In central } \\
\text { Peloponnese, and on the islands of Crete and } \\
\text { Rhodes the limestone and flysch are } \\
\text { metamorphosed into crystalline limestone and } \\
\text { phyllite }\end{array}$ & $\begin{array}{l}\text { (a) Jurassic uranium bearing phosphorite; } \\
\text { (b) Cretaceous platy limestone with } \\
\text { phosphorite; (c) flysch appears to contain } \\
\text { Au; (d) Neogene basins host peat-lignite } \\
\text { deposits; (e) small oil-fields; (f) salt domes } \\
\text { (e.g., at Monolithio); (g) low enthalpy } \\
\text { geothermal fields }\end{array}$ \\
\hline \multicolumn{3}{|c|}{ Gavrovo-Tripolis Zone } \\
\hline $\begin{array}{l}\text { Nera Kritis (11), } \\
\text { Rouva's (13), Samaria } \\
\text { (14), Lyttos (15), } \\
\text { Gortys (16), Zaro's } \\
\text { (17), Krini (19), Dikti } \\
\text { (20), Tzoumerka (35) }\end{array}$ & $\begin{array}{l}\text { A sequence of phyllite and quartzite of } \\
\text { Permo-Carboniferous to Triassic age occurs } \\
\text { as sub-basement to the Gavrovo-Tripolis } \\
\text { Zone and is rich in iron mineralisation; Tyros } \\
\text { Beds of Upper Palaeozoic to Middle Triassic } \\
\text { age consist of low grade metamorphic } \\
\text { sequence of shale, tuff, pelite, sandstone, } \\
\text { conglomerate, as well as chloritic, quartzitic } \\
\text { calc-schist with sulphide mineralisation; } \\
\text { neritic to dolomitic limestone sequence of } \\
\text { Triassic to Eocene age with flysch of Eocene } \\
\text { to Upper Oligocene age }\end{array}$ & $\begin{array}{l}\text { (a) iron mineralisation; (b) Upper Palaeozoic } \\
\text { to Middle Triassic volcanosedimentary } \\
\text { massive sulphide deposits; (c) locally } \\
\text { bauxitic episodes of Upper Cretaceous to } \\
\text { Lower Eocene age (Gavrovo mountain and } \\
\text { Pylos area) }\end{array}$ \\
\hline \multicolumn{3}{|c|}{ Pindos Zone } \\
\hline $\begin{array}{l}\text { Avra (6), Velouhi (36), } \\
\text { Krinos (39), Zefiros } \\
(40), \text { Hyas (45), Klinos } \\
(47)\end{array}$ & $\begin{array}{l}\text { Triassic volcano-clastic formation; Jurassic } \\
\text { radiolarian red-cherts associated with Mn } \\
\text { concentrations; flyschoidal and Upper } \\
\text { Cretaceous abyssal thin bedded limestone } \\
\text { with chert, and flysch of Upper Maastrichtian } \\
\text { age. Emplacement of the mafic-ultramafic } \\
\text { sequence (ophiolites) during the Upper } \\
\text { Jurassic }\end{array}$ & (a) manganese concentrations; (b) chromite \\
\hline
\end{tabular}




\begin{tabular}{|c|c|c|}
\hline Bottled water samples & Lithology & Mineralisation \\
\hline \multicolumn{3}{|c|}{ Parnassos Zone } \\
\hline & $\begin{array}{l}\text { Neritic limestone (mainly), dolomite; during } \\
\text { the Middle Jurassic, Upper Jurassic and } \\
\text { Upper Cretaceous the area was uplifted and } \\
\text { was land and during this period it received } \\
\text { sediments from the weathering and erosion of } \\
\text { ophiolites (oxides of } \mathrm{Al}, \mathrm{Fe}, \mathrm{Mg} \text {, etc.), and } \\
\text { each time a bauxitic horizon was formed; } \\
\text { flysch of mid-Eocene age }\end{array}$ & $\begin{array}{l}\text { (a) three bauxite horizons; (b) thorium- } \\
\text { uranium occurrences (e.g., Florina-Prespae) }\end{array}$ \\
\hline \multicolumn{3}{|c|}{ Pelagonian Zone } \\
\hline $\begin{array}{l}\text { Ioli (4), Drossoula } \\
\text { (10), Kimi (21), } \\
\text { Loutraki (26), Loutraki } \\
\text { Hydria (27), Loutraki } \\
\text { Karadani Provis (28), } \\
\text { Loutraki Ivi (29), Iris } \\
\text { Loutraki (30), Evdoro } \\
\text { (34), Seli (37), Vitsi } \\
\text { (48), Drossia (49) }\end{array}$ & $\begin{array}{l}\text { Mainly reef and some pelagic limestone and } \\
\text { chert of Lower Triassic to Upper Cretaceous } \\
\text { age; flysch of Upper Cretaceous to Eocene. } \\
\text { The metamorphosed part of the Pelagonian } \\
\text { zone covers part of western and central } \\
\text { Macedonia, eastern Thessaly, eastern Attiki } \\
\text { and the Cyclades Islands, and it comprises of } \\
\text { crystalline limestone, marble, foliated } \\
\text { hornfels, and schist; it also includes granite } \\
\text { and crystalline schist; ophiolite complex, sub- } \\
\text { ophiolitic melange }\end{array}$ & (a) polymetallic sulphides; (b) Mn; (c) Fe \\
\hline \multicolumn{3}{|c|}{ Axios (or Vardar) Zone } \\
\hline $\begin{array}{l}\text { Ydor Sourotis (31), } \\
\text { Pigi Paikou (38) }\end{array}$ & $\begin{array}{l}\text { Limestone, crystalline schist, marble, granite, } \\
\text { ophiolites, and flysch (slightly } \\
\text { metamorphosed) }\end{array}$ & $\begin{array}{l}\text { (a) polymetallic sulphides }(\mathrm{Cu}-\mathrm{Fe}) ;(\mathrm{b}) \mathrm{Fe}- \\
\mathrm{Ni} ; \text { (c) chromite; (d) pyrite; (e) antimony; (f) } \\
\text { molybdenite; (g) geothermal fields. }\end{array}$ \\
\hline \multicolumn{3}{|c|}{ Circum-Rhodope Zone } \\
\hline Athos (33) & $\begin{array}{l}\text { An alternating sequence of Palaeozoic shale, } \\
\text { limestone, and shale; it ends with Jurassic } \\
\text { flysch }\end{array}$ & $\begin{array}{l}\text { (a) polymetallic sulphides; (b) copper; (c) } \\
\text { Fe-Mn; (d) baryte }\end{array}$ \\
\hline \multicolumn{3}{|c|}{ Serbomacedonian Zone } \\
\hline & $\begin{array}{l}\text { Gneiss, schist, marble, amphibolite, } \\
\text { greenschist, and granite }\end{array}$ & $\begin{array}{l}\text { (a) polymetallic sulphides (Cu-Fe; } \mathrm{Pb}-\mathrm{Zn} \text {; } \\
\text { (b) } \mathrm{Cu}-\mathrm{Fe} \pm \mathrm{As} \pm \mathrm{Pb} \pm \mathrm{Zn} \text {; (c) } \mathrm{Pb}-\mathrm{Zn}-\mathrm{Au}-\mathrm{Ag} \text {; } \\
\mathrm{Pb}-\mathrm{Zn} \pm \mathrm{Cu}) ;(\mathrm{d}) \text { porphyry copper (Cu- } \\
\mathrm{Au} \pm \mathrm{Mo} \pm \mathrm{PGE}),(\mathrm{e}) \text { chromite, (f) magnetite } \\
(\mathrm{Fe}-\mathrm{Au}) ;(\mathrm{g}) \text { epithermal } \mathrm{Au} \text {; (h) antimonite } \\
(\mathrm{Sb} \pm \mathrm{W}),(\mathrm{i}) \text { iron -nickel laterite, (j) scheelite } \\
(\mathrm{W}),(\mathrm{k}) \text { molybdenite }(\mathrm{Mo}),(\mathrm{l}) \text { pyrolusite } \\
(\mathrm{Mn}-\mathrm{Fe} \pm \mathrm{Pb} \pm \mathrm{Zn} \pm A u \pm A g),(\mathrm{m}) \text { limonite (Fe- } \\
\mathrm{Au} \pm \mathrm{Mn}),(\mathrm{n}) \text { magnesite. }\end{array}$ \\
\hline \multicolumn{3}{|c|}{ Rhodope Massif } \\
\hline Beles (46) & $\begin{array}{l}\text { Marble, gneiss, crystalline schist, amphibolite } \\
\text { with marble intercalations, and granite of } \\
\text { Palaeozoic to Jurassic age; Lower Tertiary } \\
\text { volcanosedimentary sequences }\end{array}$ & $\begin{array}{l}\text { (a) massive } \mathrm{Cu} \text { mineralisation in } \\
\text { amphibolites; (b) chromite associated with } \\
\text { ophiolites; (c) manganese, (d) iron, and (c) } \\
\text { Lower Tertiary polymetallic sulphides, } \\
\text { porphyry Cu-Mo, epithermal Au, antimony } \\
\text { and uranium occurrences. }\end{array}$ \\
\hline \multicolumn{3}{|c|}{ Attico-Cycladic Complex } \\
\hline Sariza (5) & $\begin{array}{l}\text { Marble (often dolomitic), mica-amphibole- } \\
\text { schist, gneiss, metamafic rocks (greenstone?) }\end{array}$ & $\begin{array}{l}\text { (a) Fe-Mn deposits (b) polymetallic } \\
\text { sulphides; (c) iron-manganese (d) uranium } \\
\text { occurrences (e.g., Samos, Ikaria, Lesvos) }\end{array}$ \\
\hline \multicolumn{3}{|c|}{ Molasse deposits } \\
\hline Pindos (8) & $\begin{array}{l}\text { Conglomerate, marl, claystone, and sandstone } \\
\text { deposited in fault grabens, such as (a) Thrace } \\
\text { (Eocene); (b) Thessalia (Eocene to } \\
\text { Oligocene); (c) Grevena-Thessalia (Eocene to } \\
\text { Miocene), (d) Epirus (Upper Miocene) and in } \\
\text { the Attico-Cycladic Complex (Upper } \\
\text { Miocene) }\end{array}$ & \\
\hline \multicolumn{3}{|c|}{ Ophiolites } \\
\hline Samarina (9) & Basalt, diabase, gabbro, pyroxenite, & (a) chromite deposits (e.g., Vourinos, \\
\hline
\end{tabular}




\begin{tabular}{|l|l|l|}
\hline Bottled water samples & \multicolumn{1}{|c|}{ Lithology } & \multicolumn{1}{|c|}{ Mineralisation } \\
\hline & $\begin{array}{l}\text { peridotite, dunite, serpentinite (ophiolite } \\
\text { sequence) of Palaeozoic (?), Triassic to } \\
\text { Jurassic age }\end{array}$ & $\begin{array}{l}\text { Domokos, Chalkidhiki), (b) Fe-Ni laterites } \\
\text { with peridotites (e.g., Larimna, Messapia), } \\
\text { (c) magnesite (e.g., Mantoudi, Chalkidhiki), } \\
\text { (d) Cu deposits, (e) Mn deposits with cherts, } \\
\text { and (f) talc (e.g., Tinos I.) }\end{array}$ \\
\hline \multicolumn{2}{|c|}{ Igneous rocks } \\
\hline $\begin{array}{l}\text { Granitoids-granodiorite, monzonite, monzodiorite of (a) Palaeozoic age, such as Rhodope, Serbomacedonian, } \\
\text { Pelagonian and Attico-Cycladic sub-basements; (b) Triassic-Jurassic age, such as Vardar and Serbomacedonian Zones } \\
\text { (Arnaea, Fanos, Monopigadhon, etc.); (c) Eocene age, such as in the Serbomacedonian Zone and Rhodope Massif, }\end{array}$ \\
$\begin{array}{l}\text { where the Tertiary granitoids are associated with porphyry copper ore deposits; (d) Miocene age, such as in the } \\
\text { Rhodope Massif and Attico-Cycladic Complex, and (e) neo-volcanic activity from Eocene to Quaternary age, affecting } \\
\text { the whole of the internal Hellenides (from Rhodope to Pelagonian Zones) with intrusions and extrusions of rhyolite, } \\
\text { rhyodacite, dacite, andesite, trachyandesite, trachyte, tuff, ignimbrite, basalt, quartz diorite, diorite giving rise to various } \\
\text { ore deposits (Thrace area) }\end{array}$ \\
\hline
\end{tabular}

Tab. 2. Geotectonic zones of Hellas, their major lithology and mineralisation. The bottled water samples are placed in the relevant geotectonic zones. The formations begin from bottom to top, and the geotectonic zones are described from west to east (see Fig. 1)

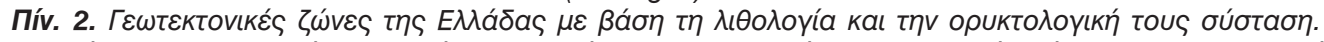

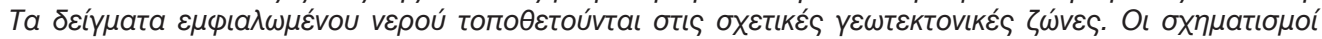

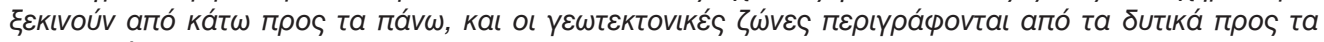

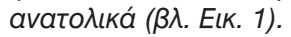

- Inductively coupled plasma atomic emission spectrometry (ICP-AES): Ba, $\mathrm{Ca}, \mathrm{K}, \mathrm{Mg}, \mathrm{Mn}, \mathrm{Na}, \mathrm{Sr}, \mathrm{P}, \mathrm{Si}$;

- Ion Chromatography (IC): $\mathrm{Br}^{-}, \mathrm{Cl}^{-}, \mathrm{F}$, $\mathrm{NO}_{2}^{-}, \mathrm{NO}_{3^{-}}, \mathrm{SO}_{4}^{2-;}$

- Atomic fluorescence spectroscopy (AFS): Hg;

- Titration: total alkalinity $-\mathrm{HCO}_{3}$;

- Photometric: $\mathrm{NH}_{4}{ }^{+}$;

- Potentiometric: $\mathrm{pH}$, and

- Conductometric: Electrical Conductivity (EC).

\subsubsection{Detection limit}

The instrument detection limit (IDL) was estimated at 3 times the standard devi- ation of sample blank determinations. The reported detection limit (RDL) was calculated at 10 times the standard deviation of sample blanks. The conservative RDL was used as the cut-off value for all statistical graphics and tables, as well as for producing the distribution maps (Tab. 3). The duplicate analyses were also used to estimate the practical detection limit and precision (see Reimann and Birke, 2010; Birke et al., 2010b).

\subsubsection{Quality control}

A very strict quality control programme was installed and reported by Reimann and Birke (2010) and Birke et al. (2010b).

\begin{tabular}{|l|l|r|r|r|r|r|}
\hline \multirow{2}{*}{ Parameter } & \multirow{2}{*}{ Unit } & \multirow{2}{*}{$R D L$} & \multirow{2}{*}{$\begin{array}{c}\text { Precision } \\
\%\end{array}$} & \multicolumn{3}{|c|}{ European results $(n=884)$} \\
\cline { 5 - 7 } & & & & Min. & Median & Max. \\
\hline $\mathrm{Ag}$ & $\mu \mathrm{g} / \mathrm{L}$ & 0.002 & 13 & $<0.002$ & $<0.002$ & 112 \\
\hline $\mathrm{Al}$ & $\mu \mathrm{g} / \mathrm{L}$ & 0.5 & 5 & $<0.5$ & 1.2 & 966 \\
\hline $\mathrm{As}$ & $\mu \mathrm{g} / \mathrm{L}$ & 0.03 & 10 & $<0.03$ & 0.24 & 90 \\
\hline $\mathrm{B}$ & $\mu \mathrm{g} / \mathrm{L}$ & 2 & 4 & $<2$ & 39 & 120000 \\
\hline $\mathrm{Ba}$ & $\mu \mathrm{g} / \mathrm{L}$ & 0.1 & 5 & 0.05 & 29 & 26800 \\
\hline $\mathrm{Be}$ & $\mu \mathrm{g} / \mathrm{L}$ & 0.01 & 5 & $<0.01$ & $<0.01$ & 64 \\
\hline $\mathrm{Bi}$ & $\mu \mathrm{g} / \mathrm{L}$ & 0.005 & - (b) & $<0.005$ & $<0.005$ & 0.69 \\
\hline $\mathrm{Br}$ & $\mu \mathrm{g} / \mathrm{L}$ & 3 & - & $<3$ & 35 & 21700 \\
\hline $\mathrm{Ca}$ & $\mathrm{mg} / \mathrm{L}$ & 0.01 & - & 0.43 & 66 & 611 \\
\hline $\mathrm{Cd}$ & $\mu \mathrm{g} / \mathrm{L}$ & 0.003 & 29 & $<0.003$ & 0.0032 & 1.1 \\
\hline $\mathrm{Ce}$ & $\mu \mathrm{g} / \mathrm{L}$ & 0.001 & 13 & $<0.001$ & $<0.001$ & 6.2 \\
\hline
\end{tabular}

\begin{tabular}{|c|c|c|}
\hline \multicolumn{3}{|c|}{ Hellenic results $(n=41)$} \\
\hline Min. & Median & Max. \\
\hline \multicolumn{3}{|c|}{ majority of values b.d.I. } \\
\hline$<0.2$ & 0.77 & 5.48 \\
\hline 0.0194 & 0.198 & 2.52 \\
\hline 2.81 & 14.6 & 143 \\
\hline$<0.005$ & 0.019 & 7.38 \\
\hline \multicolumn{3}{|c|}{ majority of values b.d.I. } \\
\hline$<0.0005$ & 0.0005 & 0.0041 \\
\hline$<0.003$ & 0.032 & 0.174 \\
\hline 2.87 & 55.4 & 101 \\
\hline$<0.001$ & 0.00259 & 0.0231 \\
\hline \multicolumn{3}{|c|}{ majority of values b.d.I. } \\
\hline
\end{tabular}




\begin{tabular}{|c|c|c|c|c|c|c|c|c|c|}
\hline \multirow{2}{*}{ Parameter } & \multirow{2}{*}{ Unit } & \multirow{2}{*}{$R D L$} & \multirow{2}{*}{$\begin{array}{c}\text { Precision } \\
\%\end{array}$} & \multicolumn{3}{|c|}{ European results $(n=884)$} & \multicolumn{3}{|c|}{ Hellenic results $(n=41)$} \\
\hline & & & & Min. & Median & Max. & Min. & Median & Max. \\
\hline $\mathrm{Cl}^{-}$ & $\mathrm{mg} / \mathrm{L}$ & 0.01 & - & 0.18 & 13 & 3627 & 1.03 & 12.8 & 81.4 \\
\hline Co & $\mu \mathrm{g} / \mathrm{L}$ & 0.01 & 5 & $<0.01$ & 0.023 & 16 & 0.004 & 0.0126 & 0.0792 \\
\hline $\mathrm{Cr}$ & $\mu \mathrm{g} / \mathrm{L}$ & 0.2 & 7 & $<0.2$ & $<0.2$ & 27 & 0.042 & 0.627 & 32.9 \\
\hline Cs & $\mu \mathrm{g} / \mathrm{L}$ & 0.002 & 3 & $<0.002$ & 0.039 & 415 & 0.0005 & 0.0045 & 4.52 \\
\hline $\mathrm{Cu}$ & $\mu \mathrm{g} / \mathrm{L}$ & 0.1 & 2 & $<0.1$ & 0.27 & 100 & 0.017 & 0.398 & 3.99 \\
\hline Dy & $\mu \mathrm{g} / \mathrm{L}$ & 0.001 & 16 & $<0.001$ & 0.0012 & 0.39 & $<0.0002$ & 0.0006 & 0.0107 \\
\hline EC & $\mu \mathrm{S} / \mathrm{cm}$ & - & - & 18 & 588 & 26500 & 177 & 434 & 891 \\
\hline $\mathrm{Er}$ & $\mu \mathrm{g} / \mathrm{L}$ & 0.001 & 13 & $<0.001$ & $<0.001$ & 0.77 & $<0.0002$ & 0.0005 & 0.0141 \\
\hline Eu & $\mu \mathrm{g} / \mathrm{L}$ & 0.001 & 18 & $<0.001$ & $<0.001$ & 0.45 & $<0.0002$ & 0.0006 & 0.0050 \\
\hline $\mathrm{F}^{-}$ & $\mathrm{mg} / \mathrm{L}$ & 0.003 & - & $<0.003$ & 0.19 & 11 & $<0.003$ & 0.05475 & 0.337 \\
\hline $\mathrm{Fe}$ & $\mu \mathrm{g} / \mathrm{L}$ & 0.5 & 4 & $<0.5$ & 0.69 & 13500 & $<0.01$ & 0.238 & 0.711 \\
\hline $\mathrm{Ga}$ & $\mu \mathrm{g} / \mathrm{L}$ & 0.005 & 4 & $<0.005$ & $<0.005$ & 3.9 & $<0.0005$ & 0.0036 & 0.0339 \\
\hline $\mathrm{Gd}$ & $\mu \mathrm{g} / \mathrm{L}$ & 0.002 & 22 & $<0.002$ & $<0.002$ & 0.66 & $<0.0002$ & 0.0008 & 0.0102 \\
\hline $\mathrm{Ge}$ & $\mu \mathrm{g} / \mathrm{L}$ & 0.03 & 6 & $<0.03$ & $<0.03$ & 110 & $<0.005$ & 0.0107 & 0.0465 \\
\hline $\mathrm{Hf}$ & $\mu \mathrm{g} / \mathrm{L}$ & 0.002 & 28 & $<0.002$ & $<0.002$ & 1.6 & \multicolumn{3}{|c|}{ majority of values b.d.l. } \\
\hline $\mathrm{Hg}$ & $\mathrm{ng} / \mathrm{L}$ & - & \multicolumn{7}{|c|}{ majority of values b.d.l. } \\
\hline Ho & $\mu \mathrm{g} / \mathrm{L}$ & 0.001 & 19 & $<0.001$ & $<0.001$ & 0.12 & $<0.0001$ & 0.0002 & 0.0046 \\
\hline I & $\mu \mathrm{g} / \mathrm{L}$ & 0.2 & 15 & $<0.2$ & 4.8 & 4030 & 0.555 & 3.28 & 12.2 \\
\hline $\mathrm{K}$ & $\mathrm{mg} / \mathrm{L}$ & 0.1 & - & $<0.1$ & 2.1 & 558 & $<0.05$ & 0.6 & 7.3 \\
\hline La & $\mu \mathrm{g} / \mathrm{L}$ & 0.001 & 9 & $<0.001$ & 0.0023 & 10 & $<0.0001$ & 0.0008 & 0.0267 \\
\hline $\mathrm{Li}$ & $\mu \mathrm{g} / \mathrm{L}$ & 0.2 & 5 & $<0.2$ & 10 & 9860 & $<0.01$ & 1.15 & 14.3 \\
\hline Lu & $\mu \mathrm{g} / \mathrm{L}$ & 0.001 & 16 & $<0.001$ & $<0.001$ & 0.41 & $<0.00005$ & 0.00009 & 0.00266 \\
\hline $\mathrm{Mg}$ & $\mathrm{mg} / \mathrm{L}$ & 0.01 & - & $<0.01$ & 16 & 4010 & 0.764 & 11.6 & 91.2 \\
\hline $\mathrm{Mn}$ & $\mu \mathrm{g} / \mathrm{L}$ & 0.1 & 2 & $<0.1$ & 0.54 & 1870 & \multicolumn{3}{|c|}{ majority of values b.d.l. } \\
\hline Mo & $\mu \mathrm{g} / \mathrm{L}$ & 0.02 & 4 & $<0.02$ & 0.28 & 74 & 0.0133 & 0.225 & 2.55 \\
\hline $\mathrm{Na}$ & $\mathrm{mg} / \mathrm{L}$ & 0.1 & - & 0.4 & 16 & 8160 & 0.7 & 7.1 & 77.2 \\
\hline $\mathrm{Nb}$ & $\mu \mathrm{g} / \mathrm{L}$ & 0.01 & 15 & $<0.01$ & $<0.01$ & 0.54 & \multicolumn{3}{|c|}{ majority of values b.d.I. } \\
\hline $\mathrm{Nd}$ & $\mu \mathrm{g} / \mathrm{L}$ & 0.001 & 18 & $<0.001$ & 0.0021 & 5.1 & 0.0003 & 0.0012 & 0.0152 \\
\hline $\mathrm{NH}_{4}{ }^{+}$ & $\mathrm{mg} / \mathrm{L}$ & 0.005 & - & 0.0025 & 0.0025 & 60 & \multicolumn{3}{|c|}{ majority of values b.d.l. } \\
\hline $\mathrm{Ni}$ & $\mu \mathrm{g} / \mathrm{L}$ & 0.02 & 4 & $<0.02$ & 0.18 & 95 & 0.011 & 0.136 & 2.4 \\
\hline $\mathrm{NO}_{2}^{-}$ & & 0.01 & \multicolumn{7}{|c|}{ majority of values b.d.l. } \\
\hline $\mathrm{NO}_{3}{ }^{\circ}$ & $\mathrm{mg} / \mathrm{L}$ & $0.01-1.0^{(\mathrm{a})}$ & - & $<1$ & 1.3 & 995 & 0.02 & 3.76 & 18.8 \\
\hline $\mathrm{P}$ & $\mu \mathrm{g} / \mathrm{L}$ & 0.01 & - & $<6.5$ & 33 & 2863 & $<0.01$ & 0.0098 & 0.0489 \\
\hline $\mathrm{Pb}$ & $\mu \mathrm{g} / \mathrm{L}$ & 0.01 & 6 & $<0.01$ & 0.016 & 2.3 & 0.001 & 0.0206 & 0.393 \\
\hline $\operatorname{Pr}$ & $\mu \mathrm{g} / \mathrm{L}$ & 0.001 & 15 & $<0.001$ & $<0.001$ & 1.5 & $<0.00005$ & 0.00017 & 0.00363 \\
\hline $\mathrm{Rb}$ & $\mu \mathrm{g} / \mathrm{L}$ & 0.01 & 6 & 0.015 & 2.1 & 631 & 0.084 & 0.34 & 5.82 \\
\hline $\mathrm{Sb}$ & $\mu \mathrm{g} / \mathrm{L}$ & 0.01 & 6 & $<0.01$ & 0.27 & 4.4 & 0.094 & 0.201 & 0.76 \\
\hline $\mathrm{Sc}$ & $\mu \mathrm{g} / \mathrm{L}$ & 0.02 & - & \multicolumn{3}{|c|}{ majority of values b.d.I. } & 0.005 & 0.0483 & 0.192 \\
\hline $\mathrm{Se}$ & $\mu \mathrm{g} / \mathrm{L}$ & 0.02 & 19 & $<0.02$ & 0.054 & 371 & 0.038 & 0.18 & 0.743 \\
\hline $\mathrm{Si}$ & $\mathrm{mg} / \mathrm{L}$ & 0.03 & - & 0.42 & 6.5 & 59 & 1.36 & 4.11 & 20.8 \\
\hline Sm & $\mu \mathrm{g} / \mathrm{L}$ & 0.001 & 23 & $<0.001$ & 0.0013 & 0.67 & 0.0001 & 0.00073 & 0.00490 \\
\hline Sn & $\mu \mathrm{g} / \mathrm{L}$ & 0.02 & 12 & $<0.02$ & $<0.02$ & 1.8 & 0.0005 & 0.00521 & 0.041 \\
\hline $\mathrm{SO}_{4}{ }^{2-}$ & $\mathrm{mg} / \mathrm{L}$ & 0.01 & - & 0.01 & 20 & 20342 & 1.65 & 8.38 & 89.7 \\
\hline $\mathrm{Sr}$ & $\mu \mathrm{g} / \mathrm{L}$ & 0.001 & - & 2 & 326 & 25500 & 0.006 & 0.118 & 0.559 \\
\hline $\mathrm{Ta}$ & $\mu \mathrm{g} / \mathrm{L}$ & 0.005 & $-^{\text {(b) }}$ & $<0.005$ & $<0.005$ & 0.037 & \multicolumn{3}{|c|}{ majority of values b.d.I. } \\
\hline $\mathrm{Tb}$ & $\mu \mathrm{g} / \mathrm{L}$ & 0.001 & 23 & $<0.001$ & $<0.001$ & 0.077 & $<0.00005$ & 0.00009 & 0.00167 \\
\hline $\mathrm{Te}$ & $\mu \mathrm{g} / \mathrm{L}$ & 0.03 & $-^{(b)}$ & $<0.03$ & $<0.03$ & 0.32 & \multicolumn{3}{|c|}{ majority of values b.d.I. } \\
\hline Th & $\mu \mathrm{g} / \mathrm{L}$ & 0.001 & 33 & 0.0005 & 0.0005 & 0.15 & $<0.0001$ & 0.00023 & 0.00265 \\
\hline $\mathrm{Ti}$ & $\mu \mathrm{g} / \mathrm{L}$ & 0.08 & 52 & 0.04 & 0.04 & 6.3 & 0.005 & 0.0211 & 0.0899 \\
\hline
\end{tabular}




\begin{tabular}{|c|c|c|c|c|c|c|c|c|c|}
\hline \multirow{2}{*}{ Parameter } & \multirow{2}{*}{ Unit } & \multirow{2}{*}{$R D L$} & \multirow{2}{*}{$\begin{array}{c}\text { Precision } \\
\%\end{array}$} & \multicolumn{3}{|c|}{ European results $(n=884)$} & \multicolumn{3}{|c|}{ Hellenic results $(n=41)$} \\
\hline & & & & Min. & Median & Max. & Min. & Median & Max. \\
\hline TI & $\mu \mathrm{g} / \mathrm{L}$ & 0.002 & 6 & $<0.002$ & 0.0041 & 2.2 & 0.0015 & 0.00675 & 0.02480 \\
\hline $\mathrm{Tm}$ & $\mu \mathrm{g} / \mathrm{L}$ & 0.001 & 22 & $<0.001$ & $<0.001$ & 0.19 & $<0.00005$ & 0.00008 & 0.00215 \\
\hline$U$ & $\mu \mathrm{g} / \mathrm{L}$ & 0.001 & 2 & 0.0005 & 0.23 & 229 & $<0.00005$ & 0.307 & 10 \\
\hline V & $\mu \mathrm{g} / \mathrm{L}$ & 0.1 & 6 & $<0.1$ & 0.17 & 49 & 0.147 & 0.676 & 7.45 \\
\hline W & $\mu \mathrm{g} / \mathrm{L}$ & 0.05 & 1 & $<0.05$ & $<0.05$ & 28 & $<0.002$ & 0.0204 & 0.106 \\
\hline $\mathrm{Y}$ & $\mu \mathrm{g} / \mathrm{L}$ & 0.001 & 7 & $<0.001$ & 0.012 & 3.5 & 0.0006 & 0.0043 & 0.267 \\
\hline $\mathrm{Yb}$ & $\mu \mathrm{g} / \mathrm{L}$ & 0.001 & 17 & $<0.001$ & $<0.001$ & 1.8 & 0.0001 & 0.00050 & 0.01650 \\
\hline $\mathrm{Zn}$ & $\mu \mathrm{g} / \mathrm{L}$ & 0.2 & 3 & $<0.2$ & 0.89 & 651 & 0.12 & 1.11 & 651 \\
\hline $\mathrm{Zr}$ & $\mu \mathrm{g} / \mathrm{L}$ & 0.001 & 7 & $<0.001$ & 0.0075 & 165 & 0.001 & 0.0016 & 0.2970 \\
\hline $\mathrm{pH}$ & - & - & - & 4 & 6.8 & 9.9 & 7.08 & 7.9 & 9.2 \\
\hline tAlk & $\mathrm{mg} / \mathrm{L}$ & 0.1 & - & 2 & 286 & 16110 & 112 & 235.46 & 472 \\
\hline Total hardness & & & & & & & 95.3 & 234 & 411 \\
\hline TDS & & & & & & & 113 & 285 & 570 \\
\hline
\end{tabular}

Tab. 3. General statistics of European and Hellenic bottled water results, reported detection limit (RDL) and precision at the 95\% confidence level (P95\%). Superscript notation: (a) depends on total dissolved solids; (b) insufficient values above detection limit to estimate reliably the precision; other notation: $E C$ electrical conductivity, tAlk - total alkalinity, TDS - total dissolved solids.

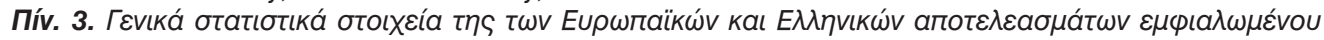

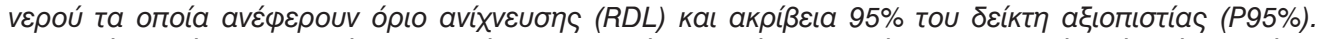

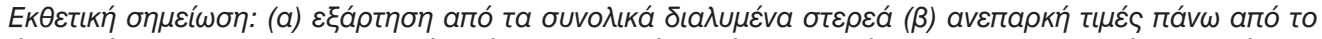

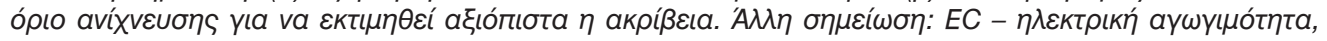

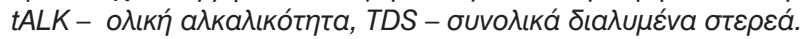

Below a concise outline is given:

(1) Analysis of international reference samples to document the trueness of analytical results, i.e., the river water reference material SLRS4 from the National Research Council Canada, and the low level fortified standards for trace elements TM-26.3, TM-27.2, TM-28.2 and TM28.3 from the National Water Research Institu-te of Canada;

(2) Frequent analysis of an in-house project standard (MinWas) to check the accuracy of determined parameters;

(3) Frequent analysis of blank samples to detect any contamination issues, and to derive reliable detection limits;

(4) Frequent analysis of sample duplicates to determine precision of measurements;

(5) Comparison of analytical results of this study with those recorded on bottle labels;

(6) Determination of a few parameters by two methods ( $\mathrm{Ba}, \mathrm{Ca}, \mathrm{K}, \mathrm{Mg}, \mathrm{Mn}$, $\mathrm{Na}, \mathrm{Sr}$ ) by ICP-QMS and ICP-AES, and $\mathrm{Hg}$ by ICP-QMS and AFS, and

(7) Buying a new bottle and re-analysing the bottled water with unusually high results for important parameters whenever possible.

A general problem of analysing so many elements, as in this study, is that there are no suitable reference materials to cover all elements, e.g., $\mathrm{Hg}, \mathrm{Ho}, \mathrm{I}, \mathrm{Lu}$, $\mathrm{Nb}, \mathrm{Nd}, \mathrm{Pr}, \mathrm{Sc}, \mathrm{Sm}, \mathrm{Ta}, \mathrm{Tb}, \mathrm{Te}, \mathrm{Th}, \mathrm{Tm}$, $\mathrm{W}, \mathrm{Y}, \mathrm{Yb}$ and $\mathrm{Zr}$.

The Canadian standards (SLRS-4, TM26.3, TM-27.2, TM-28.2 and TM-28.3) have the advantage of covering different concentration ranges for a number of elements, and were used to identify elements that presented problems at low concentrations (e.g., Hf, Nb, Sn, Ta and W), but delivered reliable results at higher values (i.e., over ten times the detection limit).

Overall, certified values, and the gener- 
ated project results, are well in agreement for most elements. Since, there exist a number of elements that are not covered by any standards, this drawback was covered by evaluating reliability of results with respect to blank values and coefficient of variation.

\subsection{Influence of bottle materials and carbonatisation}

\subsubsection{Bottle material leaching}

Many studies have demonstrated that water samples can be severely contaminated by the material of storage bottles (Lloyd and Heathcote, 1985; Hall, 1998; Reimann et al., 2007), and often extreme cleansing procedures are suggested for sample bottles (Ross, 1984), and/or the use of very expensive special plastic bottles is strongly recommended for water sampling for ultra-trace element analysis. For bottled water, a large variety of different containers are on the market (e.g., glass, hard PET, soft PET, aluminium cans, tetrapacs). Bottle materials have in addition different colours (clear, light and dark green, blue and brown are the most common colours). It must,

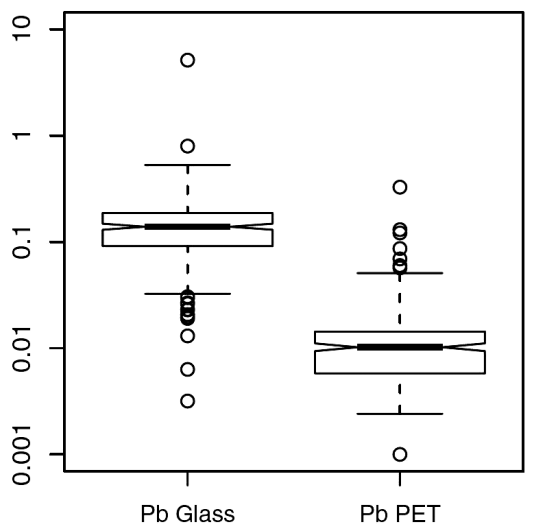

thus, be expected that each bottle type will have different properties and leaching characteristics, and will influence the stored water quality in some way. There is considerable documentation that due to the low concentrations of most elements in natural water, water sampling and analysis are required to be performed with great care in order to avoid contamination of water samples during sampling, storage, or analysis (Nriagu et al., 1993).

Glass bottles are known to leach $\mathrm{Pb}$ and $\mathrm{Zr}$ to the stored water (Misund et al., 1999). More recently, Shotyk et al. (2006), Shotyk and Krachler (2007a, b), Westerhoff et al. (2008), Keresztes et al. (2009) and Krachler and Shotyk (2009) have demonstrated that leaching of elements from bottle materials to stored water does clearly occur. For example, with respect to PET bottles Sb was identified as the main problematic element, whereas for glass leaching $\mathrm{Pb}$ (and some additional elements, see below) has been shown to be considerable in relation to natural concentrations of these elements in bottled water (Fig. 2).

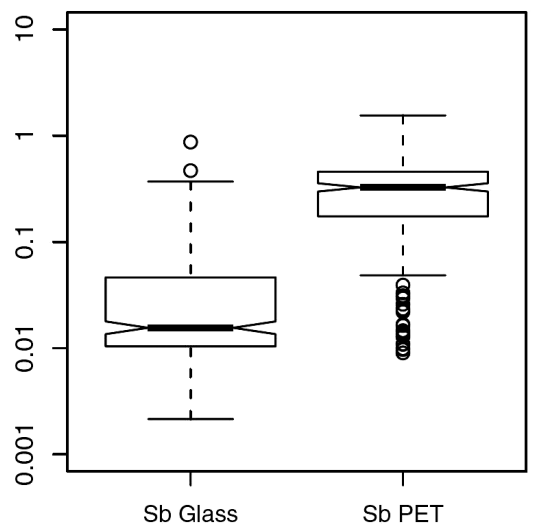

Fig. 2. Boxplot comparison of the same 131 mineral water brands sold in both glass and PET bottles. Leaching of $\mathrm{Pb}$ from glass and of Sb from PET is clearly indicated. Analytical results in $\mu \mathrm{g} / \mathrm{L}$ (from Reimann and Birke, 2010, Fig. 22, p.48).

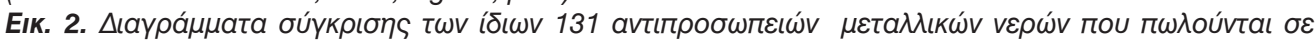

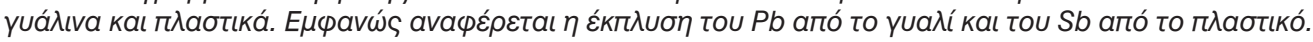

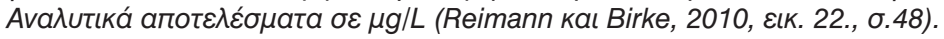


Because it was practically impossible to buy only water in a certain bottle material and colour, it was necessary to test the influence of different bottle materials and colours on element concentrations observed in stored water (Reimann and Birke, 2010; Reimann et al., 2010a;2010b). The leaching test was carried out on 126 bottles filled with high purity water $(18.2 \mathrm{Mega} \Omega / \mathrm{cm})$, and element concentrations were measured after $1,2,3,4,5,15,30,56,80$ and 150 days. The leaching tests were performed at two different $\mathrm{pH}$ values (3.5 and 6.5), and results were directly compared to actual element concentrations in bottled water. The bottle leaching results are summarised below:

- In relation to natural variation observed for the various elements in bottled water, leaching from bottle materials to stored water is a minor problem at a $\mathrm{pH}$ of 6.5. At a pH of 3.5 it becomes, however, a serious problem for quite a number of elements (e.g., glass bottles: Al, As, B, Ba, Be, Bi, Ca, Cd, Ce, $\mathrm{Co}, \mathrm{Cr}, \mathrm{Cs}, \mathrm{Cu}, \mathrm{Ga}, \mathrm{Hf}, \mathrm{I}, \mathrm{K}, \mathrm{La}, \mathrm{Li}, \mathrm{Mg}$, $\mathrm{Mn}, \mathrm{Mo}, \mathrm{Na}, \mathrm{Nb}, \mathrm{Ni}, \mathrm{Pb}, \mathrm{Rb}, \mathrm{Sb}, \mathrm{Se}$, Sn, Sr, Ta, Te, Th, Ti, Tl, U, V, W, Zn; soft PET: Ag, Dy, Er, Fe, Gd, Ge, Ho, Lu, Nd, Pr, Sm, Tb, Tm, V, Y, Yb, Zr) (Reimann et al., 2010a)

- PET bottles contaminate the water with $\mathrm{Sb}$ to an extent where all measured values cannot any longer be used to investigate natural $\mathrm{Sb}$ concentration in the water.

- Glass bottles contaminate stored water with a considerably longer list of elements: $\mathrm{Ce}, \mathrm{Pb}, \mathrm{Al}, \mathrm{Zr}, \mathrm{Ti}, \mathrm{Hf}$, Th, $\mathrm{La}, \mathrm{Pr}, \mathrm{Fe}, \mathrm{Zn}, \mathrm{Nd}, \mathrm{Sn}, \mathrm{Cr}, \mathrm{Tb}, \mathrm{Ag}, \mathrm{Er}$, $\mathrm{Gd}, \mathrm{Bi}, \mathrm{Sm}, \mathrm{Y}, \mathrm{Lu}, \mathrm{Yb}, \mathrm{Tm}, \mathrm{Nb}$ and $\mathrm{Cu}$; some glass bottles also leach $\mathrm{Sb}$.

- Green glass bottles leach more $\mathrm{Cr}(\mathrm{Fe}$, $\mathrm{Zr}$ ) to stored water than clear glass bottles and, in general, dark coloured bottles (brown, green, blue, independent of material) leach more than clear bottles.

For the purposes of the published geochemical atlas (Reimann and Birke, 2010), the following conclusions were reached:

(1) Bottled water cannot be used to establish the natural concentration range and variation of $\mathrm{Sb}$, since results from PET bottles were preferentially used for mapping.

(2) $\mathrm{Ce}, \mathrm{Cr}, \mathrm{Pb}$ and $\mathrm{Al}$ concentrations observed in bottled water can be seriously influenced by glass bottles.

(3) The majority of elements can be used to produce geochemical maps that are not seriously influenced by contamination from bottle materials.

\subsubsection{Carbonatisation effects}

Naturally carbonated waters do occur, but carbon dioxide is also added artificially to many still waters to obtain a sparkling "mineral water" variety. The content of most solutes in water should not be affected. However, for geochemical mapping, it was important to check the magnitude of any effects on the observed water chemistry for all parameters determined, because for completeness of coverage results of still and carbonated water were combined at sites where still water samples were not available.

The major effects of adding $\mathrm{CO} 2$ to bottled water is on $\mathrm{pH}$ and alkalinity. In total, 131 samples were obtained, where the same water was sold in a still and in a sparkling variant (Reimann and Birke, 2010). This subset of samples allowed the direct comparison of analytical results. The $\mathrm{pH}$ of carbonated bottled water is considerably lower than its corresponding still water (Fig. 3). The leaching tests have shown that a lower 

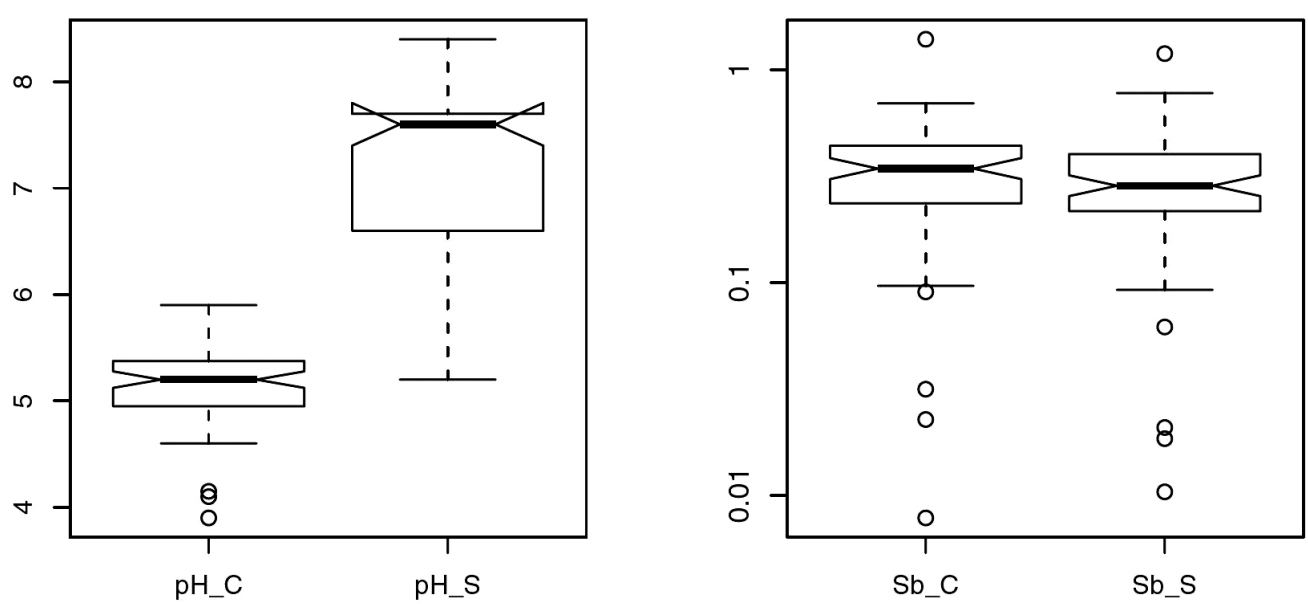

Fig. 3. Boxplot comparison of $\mathrm{pH}$ and $\mathrm{Sb}$ concentration in carbonated $(C)$ and still $(\mathrm{S})$ waters, for the same 131 pairs of bottled mineral water that are marketed both in still and carbonated variants. While $\mathrm{pH}$ is strongly affected, an effect on the Sb concentration is hardly discernible and statistically insignificant. AnaIytical results of Sb in $\mu \mathrm{g} / \mathrm{L}$, and $\mathrm{pH}$ in units (from Reimann and Birke, 2010, Fig. 24, p.50).

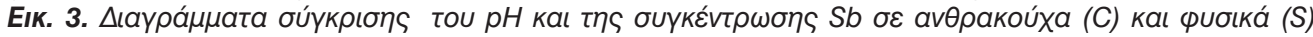

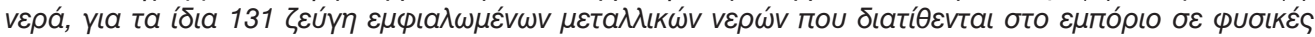

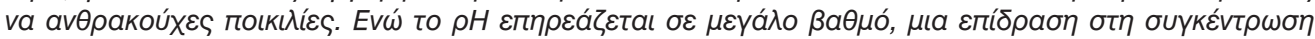

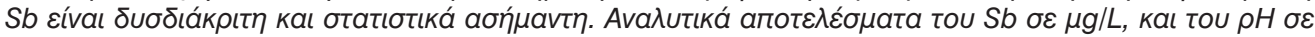



$\mathrm{pH}$ will increase leaching of elements from the bottle material to the stored water (Reimann et al., 2010a).

A difference of $2 \mathrm{pH}$ units in the median of still and carbonated water is indeed substantial.

Phosphorus shows a much lower median in still than carbonated water, which is an unexpected result. The only two elements that otherwise indicate higher concentrations in carbonated water are $\mathrm{Pb}$ and Th (Reimann and Birke, 2010; Reimann et al., 2010a).

Both elements had been identified as problematic in relation to leaching from glass bottles, and most carbonated waters are sold in glass bottles. No other element is in fact affected. It was concluded that the $\mathrm{pH}$ of carbonated water may not be low enough to substantially increase leaching from the bottle material. However, whenever possible, still water was preferred over carbonated water for plotting geochemical maps.

\subsection{Data preparation and treatment}

Since, in many cases, several brands of bottled water come from the same locality, it was decided to reduce the data set to "one bottle per site" for presentation in the geochemical atlas (Reimann and Birke, 2010). European Union regulations require that a bona fi de mineral water must have a single well dedicated to a given brand. Thus, at many mineral water bottling plants, it is common practice to have several wells, each one dedicated to a specific "brand" name. There will often be some real and significant hydrochemical variation between these different "brand" wells, even at a single site. Hence, by reducing the data set from 1247 to 884 samples, i.e., "one bottle per site", some degree of actual within site hydrochemical variation is discarded.

Due to the results of the bottle leaching test (Reimann and Birke, 2010; Reimann et al., 2010a, b), and the comparison be- 
tween carbonated and non-carbonated water, a list of priorities was established for which bottle to choose as being representative for a site:

(1) non-carbonated (still water) was preferred over carbonated water;

(2) clear PET-bottles were preferred against all other bottle materials and colours, and

(3) samples sold in glass bottles were only left in the data set when no other bottle type was available.

The above procedure resulted in a final data set containing 884 samples that was used for the extraction of statistical parameters, and construction of graphs, plots and distribution maps (Reimann and Birke, 2010). Values below detection limit were set to half the detection limit for all graphics, including distribution maps and statistical calculations.

Exploratory data analysis techniques were used for statistical analysis (Tukey, 1977). All graphics and statistical calculations were prepared in $\mathrm{R}$ (Reimann et al., 2008; CRAN, 2012). Analytical results expressed in $\mathrm{mg} / \mathrm{L}$ (or $\mu \mathrm{g} / \mathrm{L}$ ) are compositional data (Aitchison, 1986; 2003), and the calculation of mean or standard deviation does not make sense for such data (Filzmoser et al., 2009).

Mapping ground water geochemical data is plagued by many problems. The distribution of sample locations is usually very uneven, with large gaps on the maps where no samples could be taken - this is an undesirable situation in terms of obtaining a good impression of the regional distribution of investigated parameters (Reimann, 2005). It is, for example, not possible to produce smoothed colour surface maps from such data sets; even to plot readable point source maps is a challenge. Because the distribution of anomalously "high" values in Europe is probably the most interesting aspect of the published geochemical atlas (Reimann and Birke, 2010), the 'variablesize dot' or 'growing dot' technique, as originally suggested by Bjørklund and Gustavsson (1987), was used for producing all distribution maps. The technique, together with its advantages and disadvantages, is discussed in detail by Reimann et al. (2008). The variable-size dots grow exponentially according to element concentration between the 15th and 99th percentile (Gustavsson et al., 1997; Reimann et al., 2008).

\section{Results}

\subsection{European results}

The results of European ground water geochemistry (Tab. 3), using bottled water as a sampling medium, are described in the published geochemical atlas (Reimann and Birke, 2010), in a special issue of the Journal of Exploration Geochemistry (Birke et al., 2010a), and other publications (Birke et al., 2010b, c, d; Bityukova and Petersell, 2010; Bodiš et al., 2010; Brenčič and Vreča, 2010; Brenčič et al., 2010; Cicchella et al., 2010; Demetriades, 2010a, b; 2012, De Vivo et al., 2010; Dinelli et al., 2010; Dotsika et al., 2010; Frengstad et al., 2010; Fugedi et al., 2010; Lourenço et al., 2010; Lima et al., 2010; Peh et al., 2010; Reimann et al., 2010a, b; Petrović et al., 2010, 2011, 2012). Here, only some key results are presented in relation to Hellenic ground water geochemistry (Demetriades, 2010a).

\subsection{Hellenic results \\ 4.3.1. General geochemistry of source aquifers of Hellenic bottled water}

The general statistics of parameters determined on Hellenic bottled water samples $(n=41)$ are tabulated in Tab. 3 together with the corresponding European 
ones. Overall, most parameters vary by up to four orders of magnitude, and a few up to five.

The $\mathrm{pH}$ of Hellenic bottled water samples varies from 7.08 to 9.2 , with a median of 7.9. Hence, bottled water ranges from near-neutral to moderately alkaline. Total dissolved solids (TDS) in bottled water vary from 113 to $570 \mathrm{mg} / \mathrm{L}$, with a median of $285 \mathrm{mg} / \mathrm{L}$. Thus, Hellenic bottled waters belong to the low (50-250 $\mathrm{mg} / \mathrm{L})$ to moderate $(250-800 \mathrm{mg} / \mathrm{L}) \mathrm{min}$ eral content waters. Since, bottled water with TDS $<570 \mathrm{mg} / \mathrm{L}$ is classified as fresh water, according to Hem (1970), and it may be assumed that the residence time of ground water, and distance travelled, are comparatively short.

Electrical conductivity $(E C)$ varies from 177 to $891 \mu \mathrm{S} / \mathrm{cm}$, with a median of 434 $\mu \mathrm{S} / \mathrm{cm}$. These values are within the normal range for ground water, and bottled waters are, thus, classified as light $(<400 \mu \mathrm{S} / \mathrm{cm})$ to moderately heavy $(<900 \mu \mathrm{S} / \mathrm{cm})$.

Total hardness varies from 95.3 to $411 \mathrm{mg} / \mathrm{L}$, with a median of $285 \mathrm{mg} / \mathrm{L}$. Hence, the Hellenic bottled waters, according to Hem (1970), belong to the moderately hard $(61-120 \mathrm{mg} / \mathrm{L})$ to the very hard (>180 mg/L) varieties. This is understandable because of the widespread occurrence of limestone, marble and dolomite (Tab. 2).

Total alkalinity varies from 112 to 472 $\mathrm{mg} \mathrm{HCO}_{3}-/ \mathrm{L}$, with a median of $235 \mathrm{mg}$ $\mathrm{HCO}_{3}$-/L. The comparatively low alkalinity probably reflects the hydrochemicallly immature nature of bottled water sources, and also shallow aquifers.

Concentration ratios, expressed in $\mathrm{meq} / \mathrm{L}$, of a certain ion in relation to another take values that are related to (a) the aquifer host rocks, or (b) the rocks through which the water passes, or (c) the degree of replenishment of ground water, or (d) its mixing with sea water, etc. (Mandel and Shiftan 1981, Kallerghis 2000 , Soulios 2006). Below are presented various ionic relationships (Notation: after the bottled water brand name and the separation hyphen, the sample number is given, and in brackets the value of the ratio).

(a) $\mathrm{Mg}^{2+} / \mathrm{Ca}^{2+}$ ratios denote that the source water of bottled water is derived from $\mathrm{Mg}$ rich rocks or calcium carbonate lithologies:-

$>\mathrm{Mg}^{2+} / \mathrm{Ca}^{2+}>0.9$ - aquifers with silicate rich rocks rich in $\mathrm{Mg}$; aquifers associated with ophiolite formations usually have $\mathrm{Mg} / \mathrm{Ca}>1.0$ : Loutraki Karadanis Provis-28 (39.0), Loutraki Hydria-27 (38.7), Samarina-9 (12.9), Loutraki Ivi29 (12.8), Iris Loutraki-30 (12.1), Loutraki-26 (11.9), Drossia-49 (6.41), Aqua Vita-7 (5.71), and Hydor Sourotis-31 (1.96); all of these bottled waters are associated with mafic-ultramafic rocks, or ophiolitic detritus in sediments.

$>\mathrm{Mg}^{2+} / \mathrm{Ca}^{2+}=0.7-0.9$ - aquifers in dolomitic rocks: Drosoula-10 (0.81), Zaro's-17 (0.8), Samaria-14 (0.79), Rizitiko-18 (0.77), Gortys-16 (0.77), and Rouva's-13 (0.73);

$>\mathrm{Mg}^{2+} / \mathrm{Ca}^{2+}=0.5-0.7$ - aquifers in limestone or carbonate lithologies: Mythical-12 (0.69), and Ioli4 (0.59).

The $\mathrm{Mg}^{2+} / \mathrm{Ca}^{2+}$ ratio distribution map shows that the above relationships do hold (Fig. 4).

(b) $\mathrm{Na}^{+} / \mathrm{Cl}$ ratios are associated with salinisation and generally sea water intrusion, or with aquifers in which there are remnants of marine salts, or ground water passing through rocks containing evaporitic salts:-

$>\mathrm{Na}^{+} / \mathrm{Cl}^{-}>1.0$ - aquifers in alkaline 


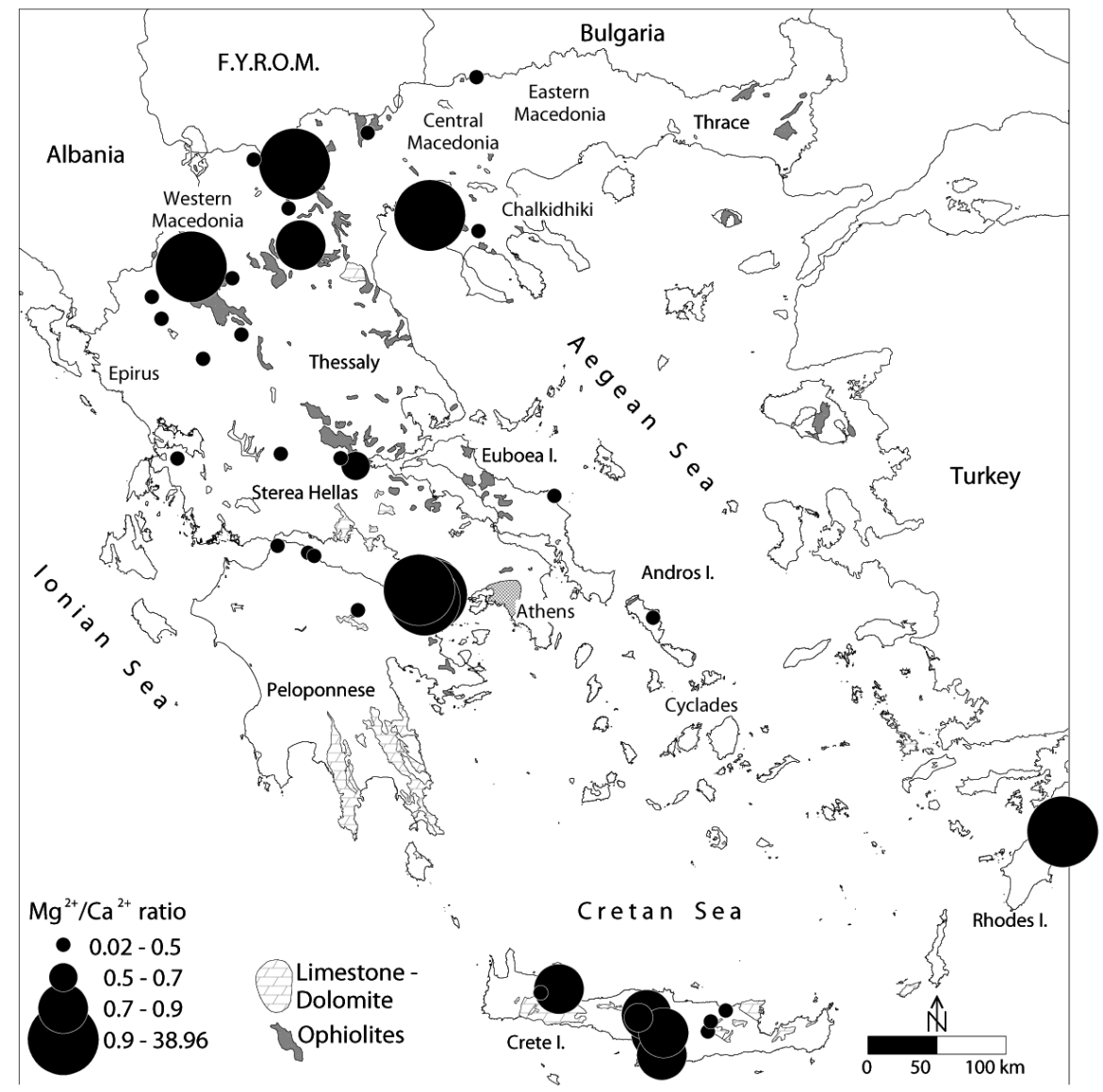

Fig. 4. Distribution of $\mathrm{Mg}^{2+} / \mathrm{Ca}^{2+}$ ratios in Hellenic bottled water samples (see also Fig. 1 and Tab. 1 for sample location numbers and brand names, respectively).

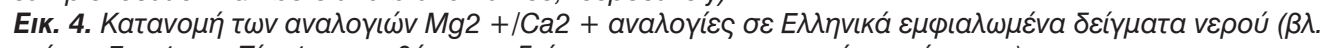

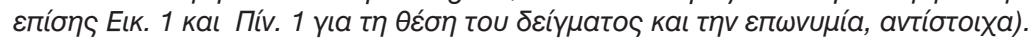

or metamorphic rocks, exchange of $\mathrm{Ca}^{2+}$ and $\mathrm{Mg}^{2+}$ by $\mathrm{Na}^{+}$, and also aquifers in flysch or water percolating through flysch, which is enriched in $\mathrm{Na}^{+}$: Beles-46 (3.82), Klinos-47 (2.04), Hyas-45 (1.85), Velouhi-36 (1.82), Aqua Vita-7 (1.76), Drosoula-10 (1.74), Vitsi-48 (1.63), Avra-6 (1.61), Zefiros-40 (1.45), Seli-37 (1.42), Tzoumerka-35 (1.41), loli-4 (1.36), Pigi Paikou-38 (1.35), Pindos-8 (1.25), Hydor Sourotis-31 (1.22), Krinos-39 (1.11), Evdoro-34 (1.09), Athos-33
(1.08), and Samarina-9 (1.0);

$>\mathrm{Na}^{+} / \mathrm{Cl}^{-}=0.876 \pm 10 \%$ (i.e., $0.78-$ $0.96)$ - normal ground water: Kimi-21 (0.9), Gortys-16 (0.88), Drossia-49 (0.86), Mythical-12 (0.84), Dikti-20 (0.82), Rouva's-13 (0.81), Samaria-14 (0.81), Korpi-3 (0.81), Zagori-2 (0.8), Nera Kritis-11 (0.79); Krini-19 (0.79), Zaro's-17 (0.78), and Rizitiko-18 (0.78);

$>\mathrm{Na}^{+} / \mathrm{Cl}^{-}<0.78$ - denotes probable pollution of the aquifer by sea water intrusion or dissolution of rem- 
nant salts within the sedimentary formations; the latter holds in this case, since isotopic studies of bottled water did not indicate any sea water intrusion in the bottled water source aquifers (E. Dotsika, person. commun., 2010): Loutraki Hydria-27 (0.74), Lyttos-15 (0.73), Sariza-5 (0.73), Iris Loutraki-30 (0.73), Loutraki Karadanis Provis-28 (0.7), Loutraki-26 (0.65), Loutraki Ivi-29 (0.65), Vikos-1 (0.63), and Eviva-22 (0.44).

(c) $\mathrm{Na}^{+} / \mathrm{K}^{+}$ratios are related to whether the source water is affected by sea or rain water, or is derived from an area of ground water recharge:-

$>\mathrm{Na}^{+} / \mathrm{K}^{+}=50-70$ - bottled water source at the down dip of the aquifer due to adsorption of Na: Nera Kritis-11 (59.1), Samaria-14 (57), Zaro's-17 (57), and Rizitiko-18 (57);

$>\mathrm{Na}^{+} / \mathrm{K}^{+} \approx 47$ - sea water: Sariza-5 (47); in this case the source water is associated with mica-schist, which is known to have elevated concentrations of $\mathrm{Cl}, \mathrm{Na}$ and $\mathrm{K}$;

$>\mathrm{Na}^{+} / \mathrm{K}^{+}=15-25$ - bottled water source in an area of ground water recharge: Hydor Sourotis-31 (25.8), Gortys-16 (25.8), Samarina-9 (23.8), Evdoro-34 (19.7), Aqua Vita-7 (18), Ioli-4 (17.6), Korpi-3 (16.7), Drossia-49 (16.2), and Velouhi-36 (14.5);

$>\mathrm{Na}^{+} / \mathrm{K}^{+}=<10$ - rain water: Seli37 (9.64), Drosoula-10 (8.84), Beles-46 (8.79), Zagori-2 (8.5), Eviva-22 (7.82), Tzoumerka-35 (5.67), Pigi Paikou-38 (5.1), Klinos-47 (4.54), and Hyas-45 (2.48); these bottled waters are situated in areas with a comparatively high annual rainfall.

(d) $\mathrm{Cl} / \mathrm{SO}_{4}{ }^{2-}$ ratios are associated with salinisation and occurrence of residual salts in the aquifers:-

$>\mathrm{Cl}^{-} / \mathrm{SO}_{4}{ }^{2-}=5-10$ - chloride rich water: Loutraki Ivi-29 (9.89), Loutraki Karadanis Provis-28 (7.03), Loutraki Hydria-27 (7.01), Loutraki-26 (6.97), Iris Loutraki-30 (6.95), and Sariza-5 (5.13);

$>\mathrm{Cl} / \mathrm{SO}_{4}{ }^{2-}=1-5$ - water rich in chloride and sulphate: Eviva-22 (4.83), Zaro's-17 (4.29), Rizitiko-18 (4.27), Nera Kritis-11 (4.05), Samaria-14 (4.02), Lyttos-15 (3.83), Aqua Vita-7 (3.05), Rouva's-13 (2.68), Mythical-12 (2.68), Hydor Sourotis-31 (2.59), Evdoro-34 (2.42), Korpi-3 (2.32), Krini-19 (1.48), Dikti-20 (1.33), Athos-33 (1.2), Pindos-8 (1.13), Vikos-1 (1.12), and Gortys-16 (1.06); the sulphate may be derived from the dissolution of gypsum or anhydrite, e.g., Hydor Sourotis is in the Anthemous Basin, where anhydrite occurs (Lambrakis and Kallergis 2005);

$>\mathrm{Cl}^{-} / \mathrm{SO}_{4}{ }^{2-}=0.2-1.0$ - water rich in sulphate-chloride: Ioli-4 (0.89), Samarina-9 (0.89)

> Avra-6 (0.76), Velouhi-36 (0.73), Klinos-47 (0.71), Drossia-49 (0.62), Tzoumerka-35 (0.56), Krinos-39 (0.55), Kimi-21 (0.54), Hyas-45 (0.54), Zagori-2 (0.51), Zefiros-40 (0.48), Beles-46 (0.47), Pigi Paikou-38 (0.29), Vitsi-48 (0.25), and Drosoula-10 (0.22);

$>\mathrm{Cl} / \mathrm{SO}_{4}{ }^{2-}<0.2$ - water rich in sulphate: Seli-37 (0.11); the sulphate in this case may be derived from the oxidation of sulphide minerals, since the aquifer is comparatively shallow and dissolved oxygen is most likely available.

(e) $\left(\mathrm{Ca}^{2+}+\mathrm{Mg}^{2+}\right) /\left(\mathrm{K}^{+}+\mathrm{Na}^{+}\right)$ratios:-

$>\left(\mathrm{Ca}^{2+}+\mathrm{Mg}^{2+}\right) /\left(\mathrm{K}^{+}+\mathrm{Na}^{+}\right)>1.0-\mathrm{aq}^{-}$ 
uifer with a continuous recharge: all bottled waters are in this category with ratio values varying from 62.87 to 1.69 , i.e., Samarina-9 (62.9), Pigi Paikou-38 (60.4), Seli37 (52.3), Drossia-49 (47), Vikos-1 (45.6), Zagori-2 (42), Eviva-22 (38.8), Tzoumerka-35 (37.3), Klinos-47 (27.2), Velouhi-36 (26), Drosoula-10 (25.6), Korpi-3 (23), Beles-46 (22.2), loli-4 (16.4), Hyas-45 (16.3), Pindos-8 (16.1), Loutraki Karadanis Provis-28 (13.6), Loutraki Hydria-27 (13), Evdoro-34 (12.8), Zefiros-40 (11.2), Loutraki-26 (10.2), Iris Loutraki-30 (9.28), Vitsi-48 (8.89), Avra-6 (8.85), Samaria-14 (8.82), Loutraki Ivi-29 (8.75), Krinos-39 (8.69), Rizitiko-18 (8.53), Zaro's-17 (8.24), Kimi-21 (7.64), Rouva's-13 (7.41), Mythical-12 (7.37), Hydor Sourotis-31 (7.31), Nera Kritis-11 (6.35), Lyttos-15 (6.17), Dikti-20 (6.1), Krini-19 (6), Gortys-16 (5.07), Athos-33 (4.96), Sariza-5 (2.11), Aqua Vita-7 (1.69). The order from high to lower $(\mathrm{Ca}+\mathrm{Mg}) /$ $(\mathrm{K}+\mathrm{Na})$ ratios almost follows the trend from areas of higher to lower annual rainfall.

(f) $\mathrm{Cl}^{-} / \mathrm{Br}^{-}$ratios are associated with mixing of fresh water with sea water, or with water in evaporitic formations or percolating through sedimentary rocks containing evaporitic salts:-

$>\mathrm{Cl} / \mathrm{Br}^{-} \approx 500-4000$ - such ratios denote water in contact with evaporites or water passing through sedimentary rocks containing disseminated evaporitic salts, and halite dissolution. All bottled waters are in this category with values varying from 4620 to 609 , i.e., Zefiros-40 (4620), Seli-37 (2765), Pindos-8 (2633), Evdoro-34
(2160), Eviva-22 (1998), Klinos-47 (1818), Vikos-1 (1278), Hyas-45 (1271), Aqua Vita-7 (1219), Ioli-4 (1215), Korpi-3 (1111), Velouhi-36 (1082), Krinos-39 (1060), Sariza-5 (1054), Hydor Sourotis-31 (1043), Avra-6 (1043), Nera Kritis-11 (1035), Lyttos-15 (1019), Zagori-2 (964), Samaria-14 (962), Kimi-21 (943), Beles-46 (939), Athos-33 (933), Vitsi-48 (902), Loutraki Ivi-29 (883), Gortys-16 (878), Rizitiko-18 (856), Zaro's-17 (850), Krini-19 (842), Iris Loutraki-30 (838), Loutraki Karadanis Provis-28 (835), Dikti-20 (835), Loutraki-26 (835), Tzoumerka-35 (819), Pigi Paikou-38 (774), Loutraki Hydria-27 (737), Mythical-12 (687), Rouva's-13 (661), Drossia-49 (640), Drosoula-10 (611), Samarina-9 (609). It is noted that the $\mathrm{Cl}-/ \mathrm{Br}$ - ratio for sea and fresh water is approximately 300 , and for syngenetic water $<300$.

TDS, total alkalinity and the $\left(\mathrm{Ca}^{2+}+\mathrm{Mg}^{2+}\right) /$ $\left(\mathrm{K}^{+}+\mathrm{Na}^{+}\right)$ratios all suggest that the source aquifers of Hellenic bottled water are shallow, and continuously replenished by fresh water. This observation is verified by the $\mathrm{Na}+/ \mathrm{K}+$ ratios, most of which have values of $<50$.

Bottled water samples have $\mathrm{Cl} / / \sum$ anion ratios varying from 0.01 to 0.43 . Since, $\mathrm{Cl} / 2$ anion ratios are $<0.8$, bottled water ground water sources are not seriously affected by dissolution of halite or other evaporitic minerals, and sites near the coast are apparently not affected by sea water intrusion. According to Hounslow (1995) ground water derived from halite dissolution would have a $\mathrm{Na}^{+} /\left(\mathrm{Na}^{+}+\right.$ $\mathrm{Cl})$ ratio of approximately equal to 0.5 , i.e., $\mathrm{Na}^{+} \approx \mathrm{Cl}$. The $\mathrm{Na}^{+} /\left(\mathrm{Na}^{+}+\mathrm{Cl}\right)$ ratios vary from 0.30 to 0.79 , suggesting that some of the bottled water sources 
do derive their salinity mainly from the dissolution of halite or evaporitic minerals within sedimentary formations, i.e., those with values $\geq 0.5$, e.g., Beles- 46 (0.79), Klinos-47 (0.67), Hyas-45 (0.65), Velouhi-36 (0.65), Aqua Vita-7 (0.64), Drosoula-10 (0.63), Vitsi-48 (0.62), Avra6 (0.62), Zefiros-40 (0.59), Seli-37 (0.59), Tzoumerka-35 (0.59), loli-4 (0.58), Pigi Paikou-38 (0.57), Pindos-8 (0.56), Hydor Sourotis-31 (0.55), Krinos-39 (0.53), Evdoro-34 (0.52), Athos-3 (0.52), Samarina-9 (0.5), Kimi-21 (0.47), Gortys-16 (0.47), Drossia-49 (0.46) and Mythical-12 (0.46). The $\mathrm{Cl} / \mathrm{Br}^{-}$ratios support the as- sumption that bottled water sources are not affected by sea water intrusion, and their salinity is derived from the dissolution of halite or evaporitic minerals within the sedimentary sequence.

Evidence of ion exchange is provided by the $\left(\mathrm{Na}^{+}-\mathrm{Cl}\right)$ versus $\left(\mathrm{Ca}^{2+}+\right.$ $\left.\mathrm{Mg}^{2+}-\mathrm{SO}_{4}{ }^{2-}-\mathrm{HCO}^{3}\right)$ diagram - Fig. 5 (Jankowski et al., 1998; Kortasi, 2006). The Hellenic bottled water samples plot approximately along a line with a slope of -1.13 , suggesting that some ion exchange is taking place, as it has been already noted in the description of $\mathrm{Na}^{+} /$ $\mathrm{Cl}^{-}$ratios.

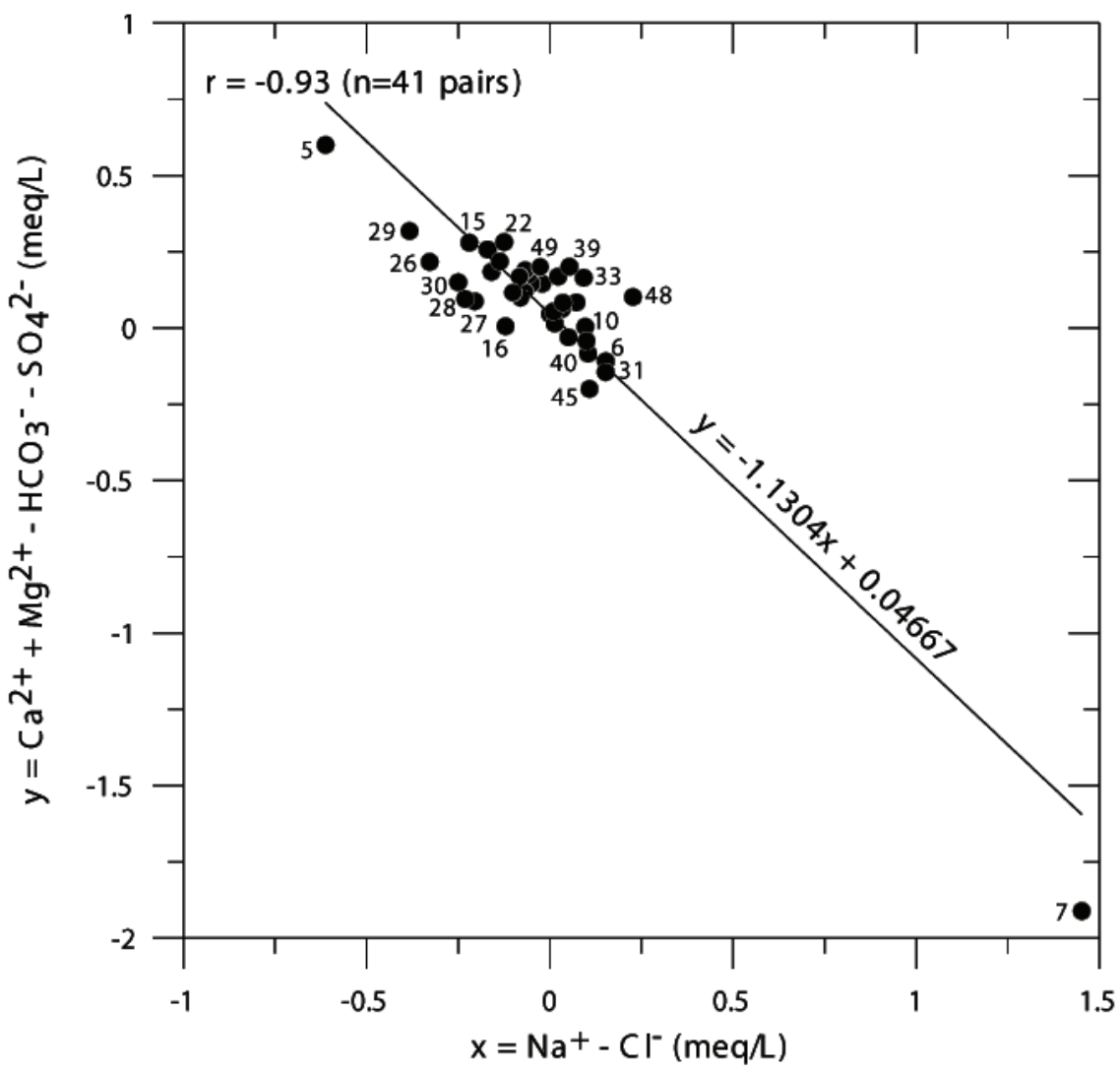

Fig. 5. Bivariate plot of $\left(\mathrm{Na}^{+}-\mathrm{Cl}\right)$ versus $\left(\mathrm{Ca}^{2+}+\mathrm{Mg}^{2+}-\mathrm{HCO}_{3^{-}-} \mathrm{SO}_{4}{ }^{2-}\right)$, Hellenic bottled water samples (for displayed sample numbers refer to Fig. 1 and Tab. 1).

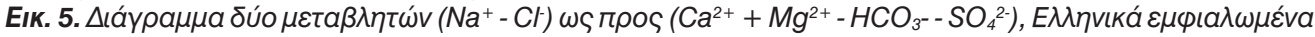

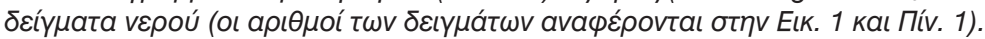




\subsection{Major ion geochemistry: Europe} Each ground water has a somewhat unique hydrochemical fingerprint that reflects the balance of all the various processes during its evolution, its residence time in the aquifer, the mineralogy of rocks and sediments that it comes into contact with, and so on. It is possible to plot major cations and anions as milliequivalent proportions on a socalled Durov diagram (Fig. 6). The major cations $\left[\mathrm{Na}^{+}\left(+\mathrm{K}^{+}\right), \mathrm{Mg}^{2+}, \mathrm{Ca}^{2+}\right]$ are plotted on the top triangle, while the major anions $\left(\mathrm{Cl}^{-}, \mathrm{SO}_{4}{ }^{2-}\right.$ and alkalinity or $\left.\mathrm{HCO}_{3}-\right)$ are plotted on the left triangle. The points are then projected onto a square central fiel d. On this diagram, dilute, newly recharged waters, which may still possess a weak signature of marine salts in coastal areas, would plot as small dots (i.e., low electrical conductivity) in the lower right field - they would be termed as a "low ionic strength $\mathrm{Na}-$ Cl" water type. More "normal" ground waters, albeit still of relatively low mineralisation, of $\mathrm{Ca}-\mathrm{HCO}_{3}$ type, derived from calcite hydrolysis (equation 1), plot in the top left.

$\begin{array}{lllll}\mathrm{CO}_{2} & +\mathrm{H}_{2} \mathrm{O} & +\mathrm{CaCO}_{3} \longrightarrow & \mathrm{Ca}^{2+} & +2 \mathrm{HCO}_{3}^{-} \\ \text {carbon } & + \text { water } & + \text { calcite } & & \text { calcium } \\ \text { dioxide } & & & \text { (dissolved) }\end{array}$

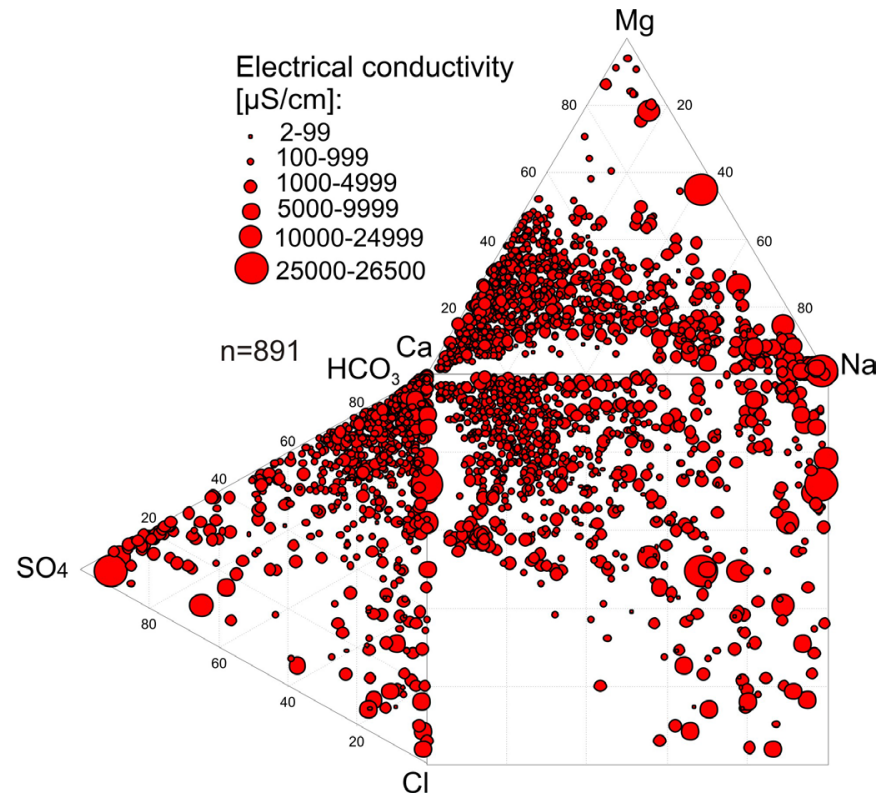

Fig. 6. Durov diagram for the European bottled water data set $(N=884)$. The diagram is based on milliequivalent fractions of the major cations and anions. The dot size is related to total dissolved solutes (on the basis of electrical conductivity). Note that for plotting the Durov diagram only $\mathrm{Na}$ and not $\mathrm{Na}+\mathrm{K}$ was used (from Reimann and Birke, 2010, Fig. 7, p.16).

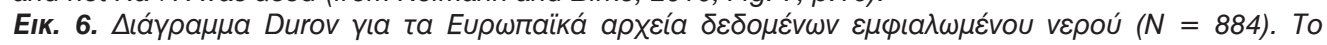

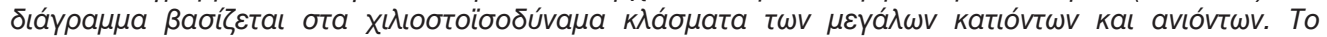

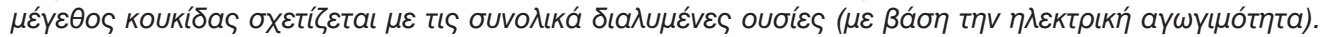



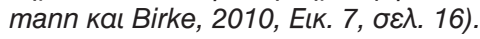




$\begin{array}{lllll}2 \mathrm{NaCaAl}_{3} \mathrm{Si}_{5} \mathrm{O}_{16}+6 \mathrm{CO}_{2} \quad+9 \mathrm{H}_{2} \mathrm{O} \longrightarrow & 2 \mathrm{Ca}^{2+} & +2 \mathrm{Na}^{+} \\ & & +6 \mathrm{HCO}_{3}^{-} & +3 \mathrm{Al}_{2} \mathrm{Si}_{2} \mathrm{O}_{5}(\mathrm{OH})_{4} \\ & & & \\ & & 4 \mathrm{SiO}_{2} & \\ \text { feldspar } & \text { carbon water } & + \text { calcium } & + \text { sodium } \\ & \text { dioxide } & & \text { +bicarbonate } & \text { +clay } \\ & & + \text { silica }\end{array}$

More evolved granitic ground waters, characterised by prolonged aluminosilicate weathering, may be of $\mathrm{Na}-\mathrm{HCO} 3$ type (equation 2), and plot at the top right. Deep saline brines would most likely be of $\mathrm{Na}-\mathrm{Cl}$ composition and plot as large-diameter dots (high electrical conductivity) near the bottom right of the diagram.

The Durov diagram shows the large variety of water types that are sold as bottled water in Europe, and describe the major ion geochemistry of ground water. The majority of samples fall, however, into the calcium bicarbonate corner of the diagram (Fig. 6).

\subsection{Major ion geochemistry: Hellas}

Instead of using the Piper and expanded Durov diagrams (Piper, 1944; Durov, 1948; Lloyd, 1965), the Chadha diagram was utilised (Fig. 7) for the Hellenic data, which is their modified version and it is much simpler to plot (Chadha, 1999; Belkiri et al., 2010). The difference is that the two equilateral triangles are omitted. However, for a more detailed study, one trilinear cations and two anions predominance diagrams, as well as a number of biplots have been plotted.

According to Chadha's diagram (Fig. 7), the majority of bottled waters belong to Group 5, the Ca-Mg$\mathrm{HCO}_{3}$ hydrochemical facies; one sample (no. 5 - Sariza) belongs to Group 1, where it means that alkaline earths $\left(\mathrm{Ca}^{2+}\right.$ $\left.+\mathrm{Mg}^{2+}\right)$ exceed the alkali metals $\left(\mathrm{Na}^{+}+\right.$ $\mathrm{K}^{+}$), and one sample (no. 7 - Aqua Vita) is in the transition zone between Group 5 and Group 3, where weak acidic anions $\left(\mathrm{CO}_{3^{-}}+\mathrm{HCO}_{3}^{-}\right)$exceed strong acidic cations $\left(\mathrm{Cl}^{-}+\mathrm{SO}_{4}{ }^{2-}\right)$. The Chadha diagram gives, in fact, a summary version of the geochemical characteristics of bottled water sources, described in detail by ionic ratios.

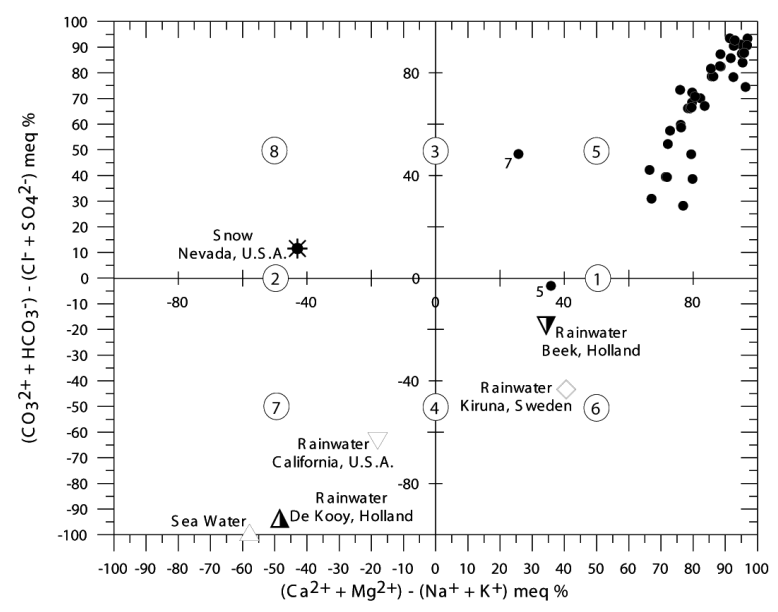

Fig. 7. Geochemical classification and hydrochemical processes of ground water depicted by bottled water, Hellas (after Chadha, 1999, Fig. 3, p.434; for displayed sample numbers refer to Fig. 1 and Tab. 1).

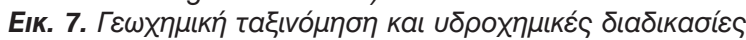

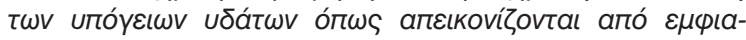

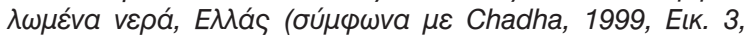

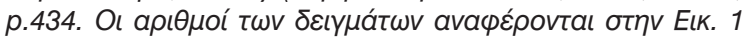
kaı Пív. 1). 
The trilinear cations predominance diagram shows that the majority of bottled water samples are dominated by $\mathrm{Ca}$, and are, thus, classified as 'calcium-rich' water types (Fig. 8). The predominance of $\mathrm{Ca}$ is understandable, because of the widespread occurrence of calcium or calcium releasing lithologies in $\mathrm{Hel}-$ las, e.g., karstic limestone, mafic-ultramafic sequences (ophiolites), but also sedimentary rocks rich in calcium. Some bottled waters fall in the 'magnesium-rich' field, and these are associated with mafic-ultramafic rocks (ophiolites) and dolomitic limestone, i.e., weathering of Mg-rich minerals, such as olivine and pyroxene (Samarina-9), sediments containing a large propor- tion of ophiolitic detritus (Loutraki-26, Loutraki Hydria-27, Loutraki Karadanis Provis-28, Loutraki Ivi-29, Iris Loutraki-30), and dolomitised marble and ophiolites (Drossia-49), limestone and conglomerate with ophiolitic detritus (Hydor Sourotis-31), and limestone and ophiolitic rocks (Aqua Vita-7). Sample 5 (Sariza) from Andros Island falls in the mixed zone and is enriched in $\mathrm{Na}$, presumably derived from the dissolution of albite $\left(\mathrm{NaAlSi}_{3} \mathrm{O}_{8}\right)$ occurring in the mica schist; a plausible explanation for samples 16 (Gortys) and 17 (Zaro's) from Crete Island is the derivation of $\mathrm{Mg}$ from dolomitised limestone, and $\mathrm{Na}$ from the dissolution of sodium-rich minerals in the flysch.

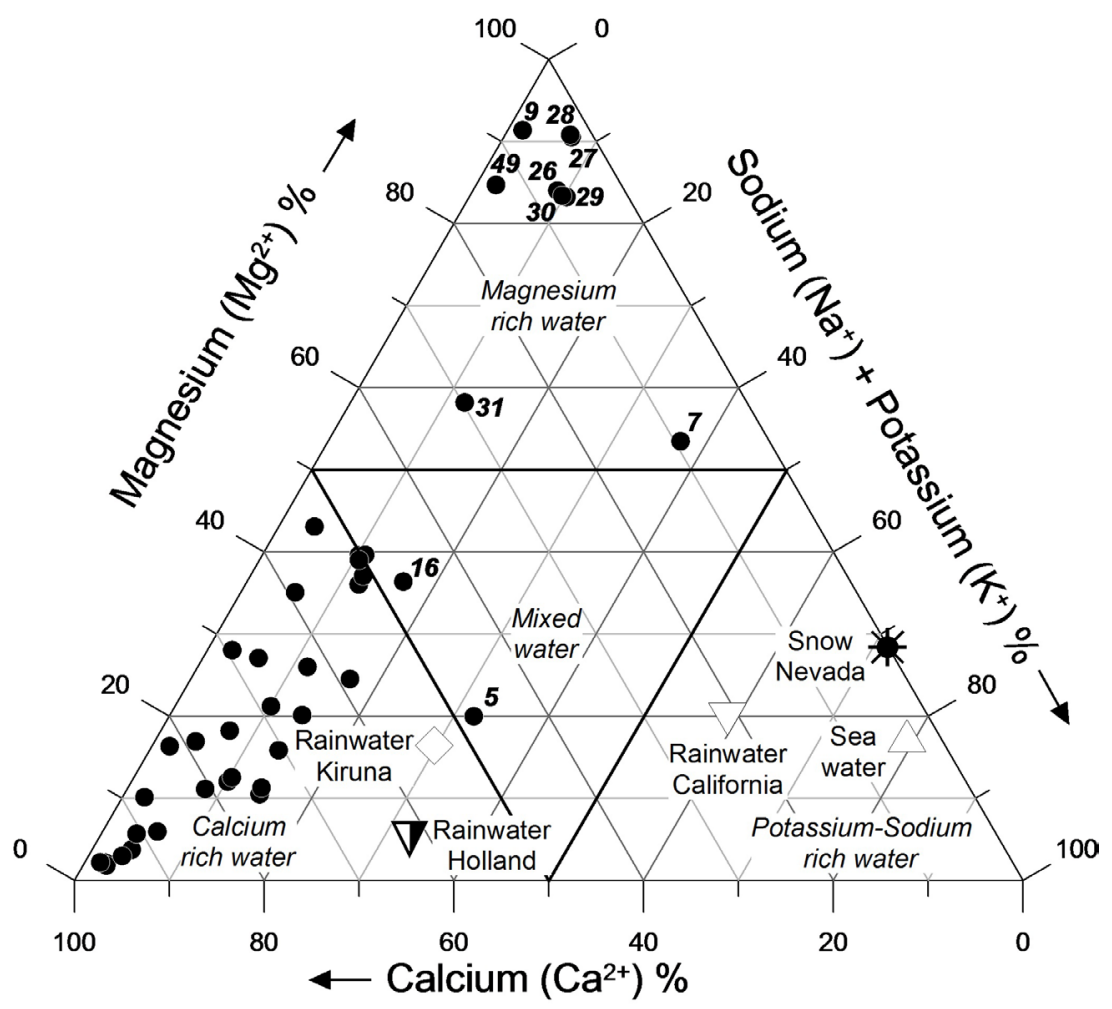

Fig. 8. Trilinear predominance diagram for the cations [Calcium-Magnesium-(Sodium+Potassium)] in Hellenic bottled water (for displayed sample numbers refer to Fig. 1 and Tab. 1).

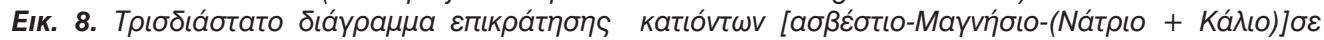

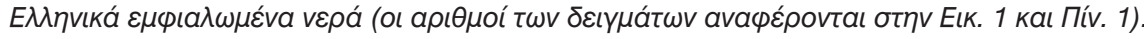


The two anions predominance diagrams $\left[\mathrm{HCO}_{3^{-}}-\mathrm{SO}_{4}{ }^{2-}-\left(\mathrm{Cl}+\mathrm{NO}_{3}{ }^{-}\right)\right]$(Figure 9a) and $\left[\mathrm{Cl}^{-}-\mathrm{SO}_{4}{ }^{2-}-\left(\mathrm{CO}_{3}{ }^{2-}+\mathrm{HCO}_{3}-\right)\right]$ (Fig. $9 \mathrm{~b})$, provide additional information of the controls on ground water geochemistry, and an understanding of water-rock interactions that are dominant in Hellenic aquifers. The majority of Hellenic bottled waters fall in the field of 'bicarbonaterich' and 'carbonate-bicarbonate rich' waters (Figs 9a and 9b), suggesting dissolution of carbonate bearing minerals from the weathering of mafic-ultramafic rocks (ophiolites), limestone, marble, and sediments rich in carbonates. On both diagrams sample 5 (Sariza) from Andros Island falls in the mixed zone, possibly suggesting interaction of ground water with the mica-schist, which is known to have elevated concentrations of $\mathrm{Cl}, \mathrm{Na}$ and $\mathrm{K}$; see also diagrams of $\mathrm{Na}^{+} / \mathrm{Cl}^{-}$versus $\mathrm{Cl}^{-}$(Fig. 10a) and $\mathrm{Na}^{+}$versus $\mathrm{Cl}^{-}$(Fig. 10b).

The $\mathrm{Na}^{+}$versus $\mathrm{Cl}^{-}$biplot shows that the bottled water samples plot very close to the $1: 1 \mathrm{Na}: \mathrm{Cl}$ sea water - rainwater mixing line, with a slight dominance of $\mathrm{Na}$
(Fig. 10b).

This perhaps suggests an increase of the ground water's weathering capacity due to the probable presence of high $\mathrm{CO}_{2}$ concentrations that favour the solubility of alkaline elements from siliceous rocks (Ellis and Mahon, 1977; Lambrakis and Kallerghis, 2005). In such a case, there may be remobilisation of sodium from Na-bearing silicate rocks, thus causing an increase in the $\mathrm{Na}^{+}: \mathrm{Cl}$ ratio above the sea water - rainwater mixing line (Figs 10a and 10b). Samples 5 (Sariza) and 7 (Aqua Vita) have elevated $\mathrm{Na}$ and $\mathrm{Cl}$ concentrations, and because they are situated on islands, and near the coast, they may be ascribed to a marine influence. However, their isotopic composition does not support such an explanation (E. Dotsika, pers. commun., 2010), and are attributed to geogenic sources. In addition, Sariza-5 is associated with mica-schist, which is known to have elevated concentrations of $\mathrm{Cl}, \mathrm{Na}$ and $\mathrm{K}$, whereas Aqua Vita-7 most likely picks up $\mathrm{Na}^{+}$and $\mathrm{Cl}$ - ions from remnant salts within the marine sediments.
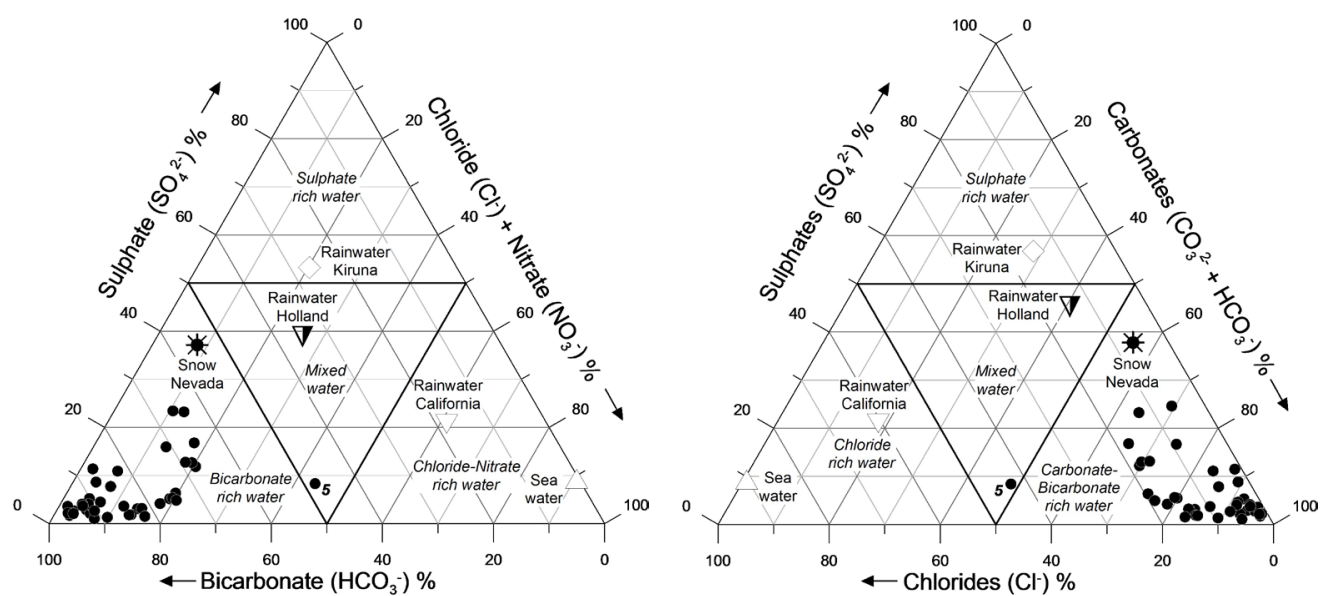

Fig. 9. Trilinear predominance diagram for the anions in Hellenic bottled water: (a) Bicarbonate-Sulphate(Chloride+Nitrate) and (b) Chlorides-Sulphates-Carbonates (for displayed sample numbers refer to Fig. 1 and Tab. 1).

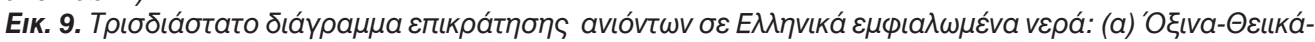

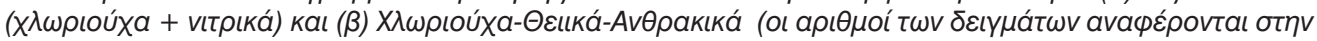
Eıк. 1 кaı Пív. 1). 

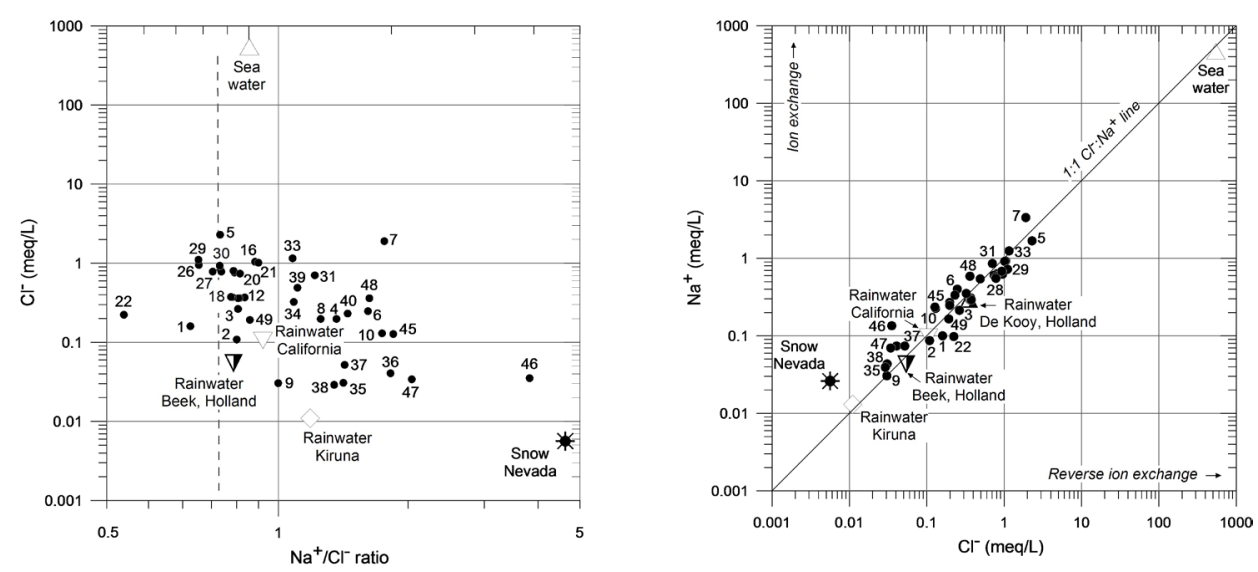

Fig. 10. Logarithmic plots of relationships between concentration of chemical species: (a) $\mathrm{Na}^{+} / \mathrm{Cl}^{-}$versus $\mathrm{Cl}$; (b) $\mathrm{Cl}$ vs. $\mathrm{Na}^{+}$(for displayed sample numbers refer to Fig. 1 and Tab. 1).

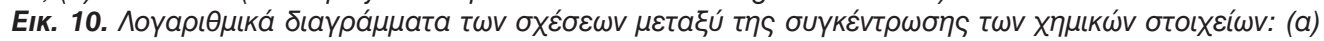

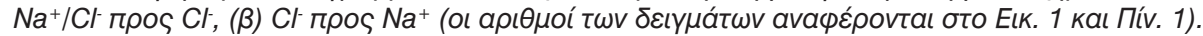

Other interesting ion biplots are:

(a) $\mathrm{Ca}^{2+}$ versus $\mathrm{Cl}^{-}$(Fig. 11a): the majority of bottled water samples fall in the $\mathrm{Ca}^{2+}$ field, except Sariza-5 (Andros I.), Aqua Vita-7 (Rhodes I.), Loutraki-26, Loutraki Hydria-27, Loutraki Karadanis Provis-28, Loutraki Ivi-29, Iris Loutraki-30, which have elevated $\mathrm{Cl}$ - concentrations that may be due to meteoric input, but also geogenic sources;

(b) $\mathrm{Mg}^{2+}$ versus $\mathrm{Cl}$ (Fig. 11b): the majority of bottled water samples fall in the $\mathrm{Mg}^{2+}$ field, because of water-rock interactions with dolomitic limestone, and ophiolites or ophiolitic detritus in sediments; sample numbers Sariza-5 (Andros I.), Krini-19 and Dikti-20 (Crete I.), Korpi-3, and Vikos-1 fall in the $\mathrm{Cl}^{-}$field, suggesting dissolution of chloride-rich minerals from mica schist in the case of Sariza-5, and sediments; for the last two samples evaporites may play a role;

(c) $\mathrm{B}^{3+}$ versus $\mathrm{Cl}^{-}$(Fig. 11c): all bottled water samples fall in the boron field, a feature attributed to intensified water-rock interactions (Lambrakis and Kallergis, 2005); (d) $\mathrm{NO}_{3}$ - versus $\mathrm{Cl}-$ (Fig. 11d): the majority of bottled water samples fall in the elevated $\mathrm{NO}_{3}$ - concentrations field, indicating the participation of fresh surface water in the replenishment of aquifers. Gortys-16 (Crete I.) and Kimi-21 (Euboea I.) have the lowest $\mathrm{NO}_{3}$ - levels. As has already been pointed out in the discussion of the $\mathrm{Na}^{+} / \mathrm{Cl}^{-}$and $\mathrm{Na}^{+} /\left(\mathrm{Na}^{+}+\mathrm{Cl}\right)$ ratios, elevated $\mathrm{Cl}^{-}$concentrations may be due to dissolution of halite or evaporitic minerals from marine sediments. Biplots of cations also show interesting features, e.g.,

(i) $\mathrm{Na}^{+}$versus $\mathrm{K}^{+}$(Fig. 12a): all bottle water samples fall in the $\mathrm{Na}$ field, and apart from sample 45 (Hyas), they are below the sea water-rainwater mixing line; this feature indicates that the bottled water's ground water source is richer in $\mathrm{Na}$ than $\mathrm{K}$, and

(ii) $\left(\mathrm{Na}^{+}+\mathrm{K}^{+}\right)$versus $\left(\mathrm{Ca}^{2+}+\mathrm{Mg}^{2+}\right)$ (Figure 12b): all bottled water samples fall in the $\left(\mathrm{Ca}^{2+}+\mathrm{Mg}^{2+}\right)$ field, suggesting that these two cations are the most important in Hellenic ground waters, since the dominant rock types are $\mathrm{Ca}$ and $\mathrm{Mg}$ rich, as has already been mentioned. 

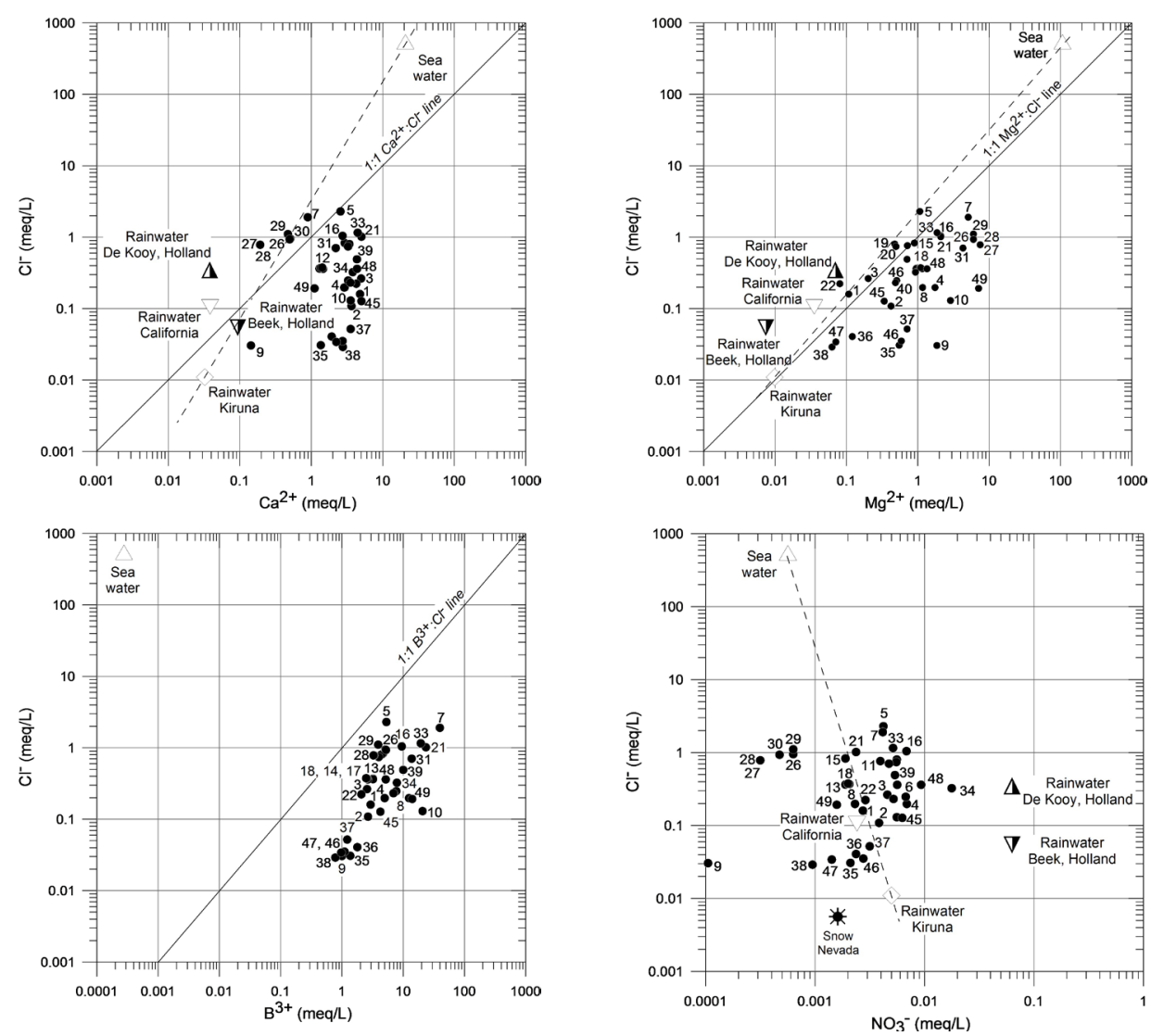

Fig. 11. Logarithmic plots of relationships between concentration of chemical species: (a) $\mathrm{Ca}^{2+} \mathrm{vs} . \mathrm{Cl}$; (b) $\mathrm{Mg}^{2+}$ vs. $\mathrm{Cl}$; (c) $\mathrm{B}^{3+}$ vs. Cl; (d) $\mathrm{NO}_{3^{-}}$vs. $\mathrm{Cl}$ (for displayed sample numbers refer to Fig. 1 and Tab. 1).

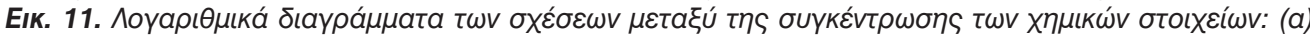

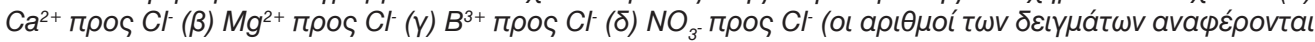

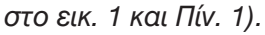
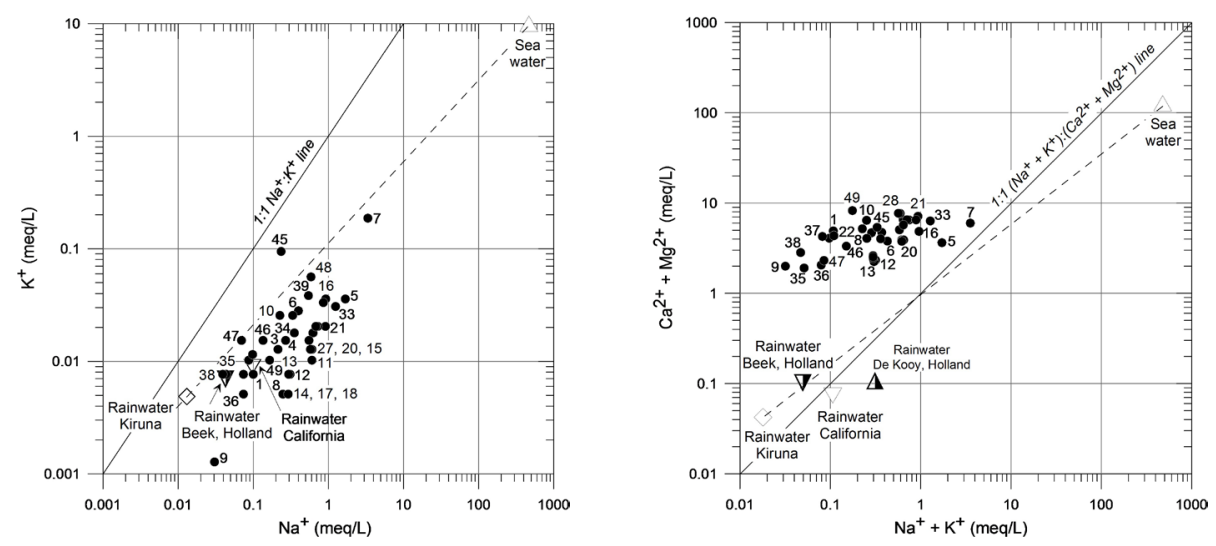

Fig. 12. Logarithmic plots of relationships between concentration of chemical species: (a) $\mathrm{Na}^{+} v s . \mathrm{K}^{+}$and (b) $\left(\mathrm{Na}^{+}+\mathrm{K}^{+}\right)$vs. $\left(\mathrm{Ca}^{2+}+\mathrm{Mg}^{2+}\right)$ (for displayed sample numbers refer to Fig. 1 and Tab. 1).

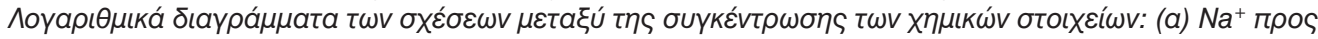

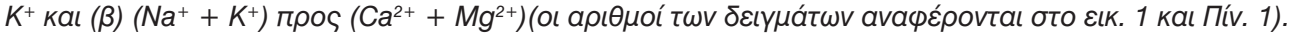




\subsubsection{Gypsum solubility and related plots: Hellas}

Gypsum $\left(\mathrm{CaSO}_{4} \cdot 2 \mathrm{H}_{2} \mathrm{O}\right)$ and anhydrite $\left(\mathrm{CaSO}_{4}\right)$ occur as primary minerals in evaporite formations, and as secondary minerals in other sedimentary sequences, especially in the Paxos and Axios geotectonic zones (Fig. 1), but also in the Tertiary sedimentary formations. Since, gypsum could be an important control on the solubility of $\mathrm{Ca}^{2+}$ and $\mathrm{SO}_{4}{ }^{2-}$, and may limit concentrations of these ions in solution, the gypsum saturation index diagram was plotted (Fig. 13). All bottled water samples fall in the undersaturated field with respect to the gypsum equilibrium line. This condition may be explained by other controls on the concentration of $\mathrm{Ca}^{2+}$ and $\mathrm{SO}_{4}{ }^{2-}$ in solution, which include insufficient sources of these elements from aquifer lithologies, or the occurrence of lower solubility minerals, which limit the concentration of either ion in solution, such as calcite (Ander et al., 2006) that occurs in the Hellenic lithologies.

Since, the bottled water samples are undersaturated with respect to gypsum, it appears that this mineral phase is not expected to be an important control on concentrations of $\mathrm{Ca}^{2+}$ and $\mathrm{SO}_{4}{ }^{2-}$ in the source rocks of these waters, or the formations through which ground water passes.

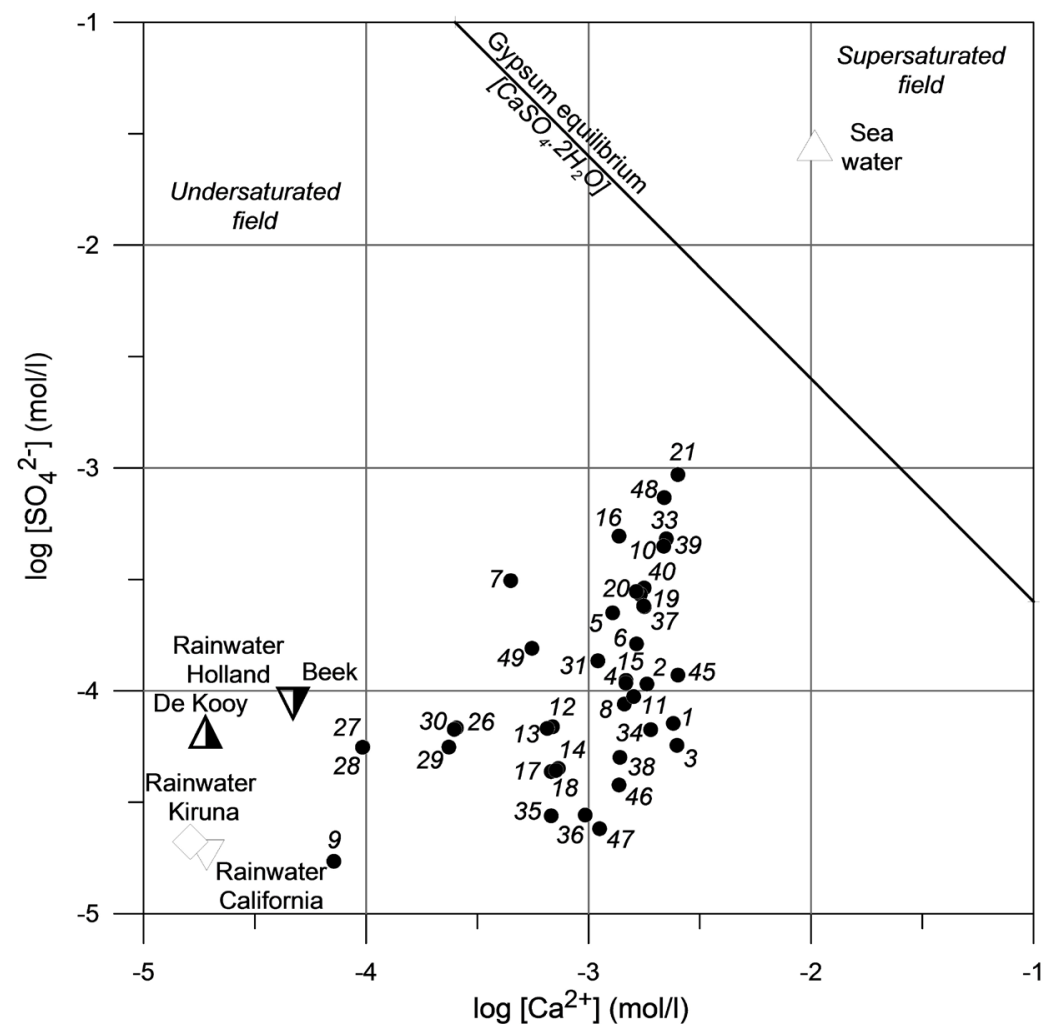

Fig. 13. Comparison of the Hellenic bottled water data with the gypsum saturation index (for displayed sample numbers refer to Fig. 1 and Tab. 1).

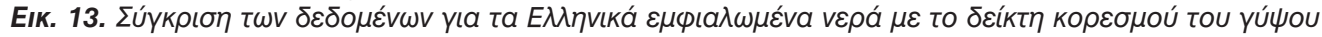

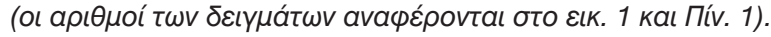



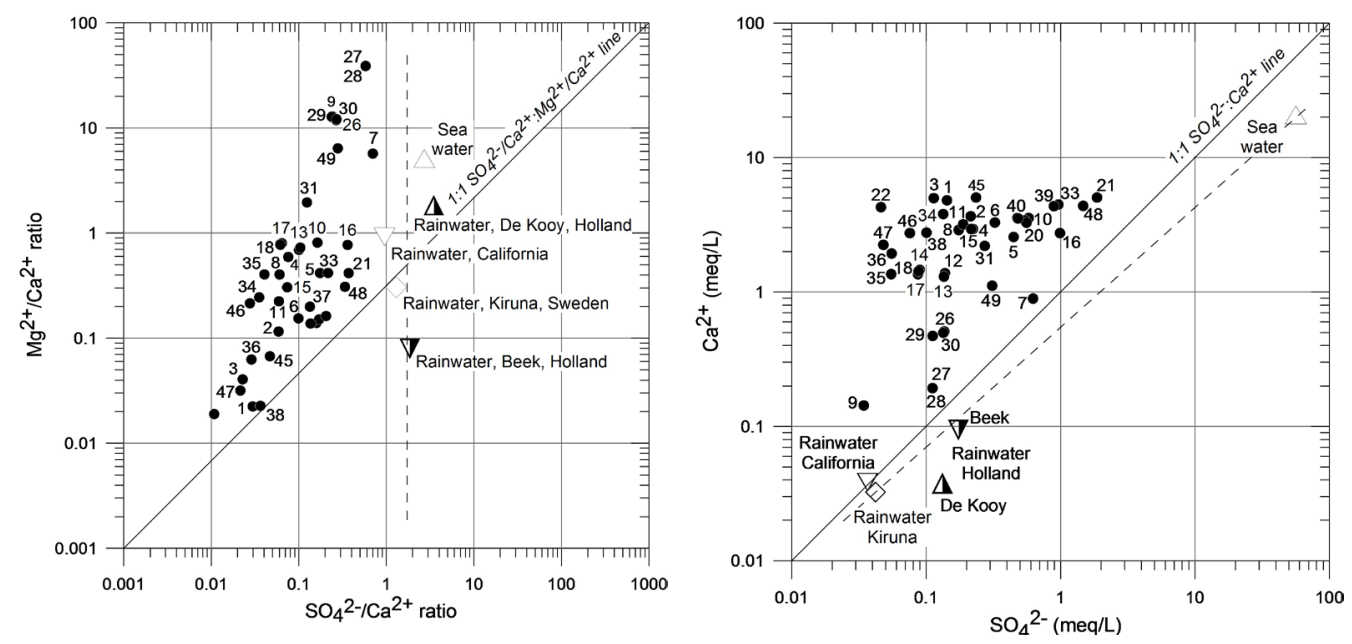

Fig. 14. Logarithmic plots of relationships between concentration of chemical species: (a) $\mathrm{SO}_{4}{ }^{2-} / \mathrm{Ca}^{2+}$ vs. $\mathrm{Mg}^{2+} / \mathrm{Ca}^{2+}$ ) and (b) $\mathrm{SO}_{4}{ }^{2-}$ vs. $\mathrm{Ca}^{2+}$ (for displayed sample numbers refer to Fig. 1 and Tab. 1).

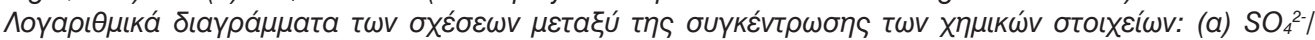

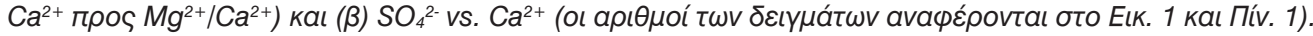

This observation is further supported by the ratio plots of $\mathrm{SO}_{4}{ }^{2-} / \mathrm{Ca}^{2+}$ versus $\mathrm{Mg}^{2+} /$ $\mathrm{Ca}^{2+}$ (Fig. 14a), and $\mathrm{SO}_{4}{ }^{2-}$ versus $\mathrm{Ca}^{2+}$ (Fig. 14b), which show that all Hellenic bottled water samples fall in the $\mathrm{Ca}^{2+}$ and $\mathrm{Mg}^{2+} / \mathrm{Ca}^{2+}$ fields, respectively.

\subsection{Trace element geochemistry: Europe and Hellas}

Three trace elements were selected for discussion, chromium, vanadium and uranium, because they are significant to the geology of Hellas and are affecting the chemical composition of ground water.

\subsubsection{Chromium distribution: Europe}

Chromium in European bottled water varies from $<0.2$ to $27.2 \mu \mathrm{g} / \mathrm{L}(\mathrm{n}=884)$, with a median of $<0.2 \mu \mathrm{g} / \mathrm{L}$ (Table 3; Reimann and Birke 2010), and in European surface water, $\mathrm{Cr}$ has a wider range from $<0.01$ to $43 \mu \mathrm{g} / \mathrm{L}(\mathrm{n}=806)$, and its median is slightly higher at 0.38 $\mu \mathrm{g} / \mathrm{L}$ (Salminen et al., 2005). Whereas, $\mathrm{Cr}$ in Hellenic bottled water varies from $<0.2$ to $32.9 \mu \mathrm{g} / \mathrm{L}(\mathrm{n}=41)$, with a median $0.627 \mu \mathrm{g} / \mathrm{L}$, and the Hellenic surface water has a narrower range from 0.24 to $6.37 \mu \mathrm{g} / \mathrm{L}(\mathrm{n}=27)$, and a slightly lower median at $0.57 \mu \mathrm{g} / \mathrm{L}$ (Salminen et al., 2005); the reason for the difference between the maximum value of European and Hellenic bottled water suites is because of the inclusion of samples that were excluded from the European database.

The main pattern on the European $\mathrm{Cr}$ distribution map is an extensive anomaly in SE-Europe (Albania, Hellas) (Fig. 15). Northern Europe shows generally slightly lower Cr-levels in bottled water. Geology, and especially the occurrence of mafic and ultramafic rocks (such as ophiolites), is very important for the distribution of $\mathrm{Cr}$ in the surface environment. Over $2000 \mathrm{mg} / \mathrm{kg} \mathrm{Cr}$ occur in rocks and soils associated with the presence of ultramafic rocks. It is, thus, perhaps not surprising that the main anomaly on the distribution map is located in SE-Europe, with its abundance of ophiolites in Albania and Hellas. Note also the high value in Cyprus, with its famous Troodos ophiolite complex. 
Many enhanced $\mathrm{Cr}$ values are observed in Germany, where the use of glass bottles is widespread. One can speculate whether leaching of $\mathrm{Cr}$ from the glass bottles could lead to somewhat enhanced German $\mathrm{Cr}$ concentrations.

The six highest $\mathrm{Cr}$ values (up to 27.2 $\mu \mathrm{g} / \mathrm{L}$ ), however, are all reported from Hellas and are related to the occurrence of ultramafic rocks or to ultramafic detritus in sediments, i.e., Drossia-49 (32.9 $\mu \mathrm{g} / \mathrm{L})$, Ydor Sourotis-31 $(27.2$ $\mu \mathrm{g} / \mathrm{L})$, Iris Loutraki-30 (23.6 $\mu \mathrm{g} / \mathrm{L})$, Loutraki-26 $(22.4 \mu \mathrm{g} / \mathrm{L})$, Loutraki Karadanis Provis-28 (20.1 $\mu \mathrm{g} / \mathrm{L})$, Loutraki Hydria-27 (19.6 $\mu \mathrm{g} / \mathrm{L})$, Loutraki Ivi-29 (17.8 $\mu \mathrm{g} / \mathrm{L})$ (see Fig. 16).
Bottle material leaching test has shown that glass bottles (especially green glass) can leach significant amounts of $\mathrm{Cr}$ (up to $0.2 \mu \mathrm{g} / \mathrm{L}-2 \mu \mathrm{g} / \mathrm{L}$ at $\mathrm{pH}$ 3.5) to the stored water.The Hellenic samples were all in PET bottles.

The European Union limit for chromium in drinking and mineral water is $50 \mu \mathrm{g} / \mathrm{L}$ (Tab. 2; EC Directive 2003/40/EC).

Even the maximum concentration found in Hellenic bottled water $(32.9 \mu \mathrm{g} / \mathrm{L})$ is well below this limit.

\subsubsection{Vanadium distribution}

Vanadium in European bottled water varies from $<0.1$ to $48.9 \mu \mathrm{g} / \mathrm{L}(\mathrm{n}=884)$, with a median of $0.17 \mu \mathrm{g} / \mathrm{L}$ (Tab. 3; Rei-
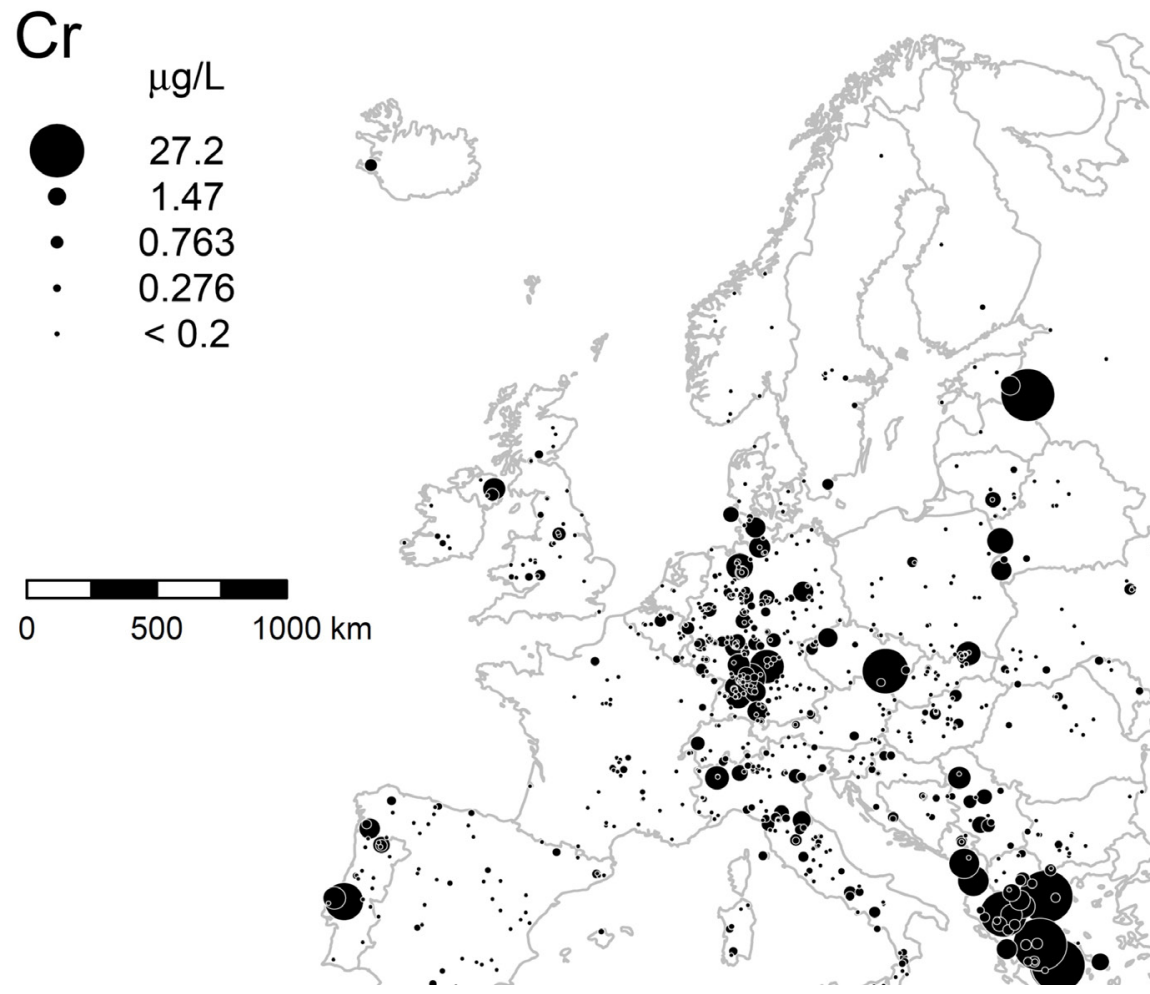

Fig. 15. Distribution of chromium (Cr) in European bottled water samples (from Reimann and Birke, 2010, p.99).

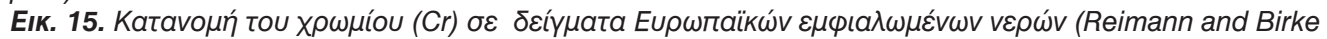

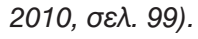




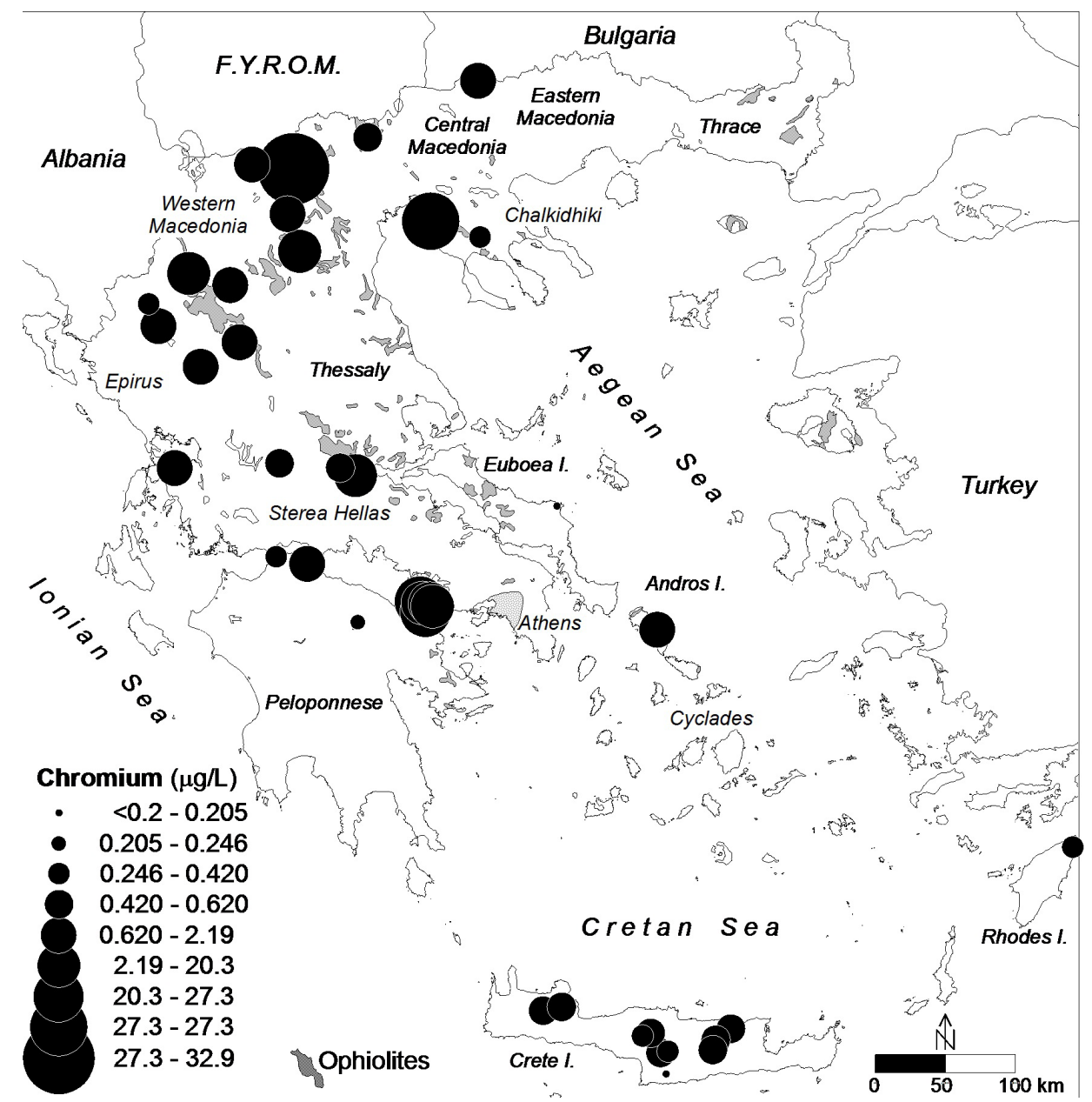

Fig. 16. Distribution of chromium (Cr) in Hellenic bottled water samples (see also Fig. 1 and Tab. 1 for sample location numbers and brand names, respectively).

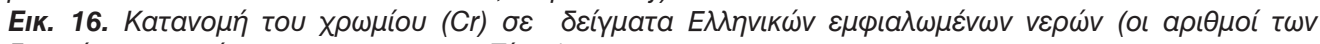

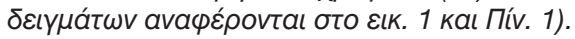

mann and Birke, 2010), and in European surface water $V$ has a narrower range from $<0.05$ to $19.5 \mu \mathrm{g} / \mathrm{L}(\mathrm{n}=807)$, and its median is slightly higher at $0.46 \mu \mathrm{g} / \mathrm{L}$ (Salminen et al., 2005). Whereas, $\mathrm{V}$ in Hellenic bottled water varies from 0.147 to $7.45 \mu \mathrm{g} / \mathrm{L}(\mathrm{n}=41)$, with a median 0.676 $\mu \mathrm{g} / \mathrm{L}$, and in Hellenic surface water it has a slightly wider range from 0.17 to 12.40 $\mu \mathrm{g} / \mathrm{L}(\mathrm{n}=27)$, with an approximately similar median $0.70 \mu \mathrm{g} / \mathrm{L} \mathrm{V} \mathrm{(Salminen} \mathrm{et} \mathrm{al.,}$ 2005).
On the $\mathrm{V}$ distribution map (Fig. 17), all the active volcanic areas in Europe are clearly marked by anomalies (e.g., Iceland, Canary Islands, Cyprus, Italy). In France, a $V$ anomaly coincides with the Massif Central, possibly linked to volcanic lithologies. In North Ireland, the influence of the Palaeogene basalt is visible. The highest vanadium value (48.9 $\mu \mathrm{g} / \mathrm{L}$ ) was reported from an Italian bottled water and is linked to the alkaline volcanic province. 


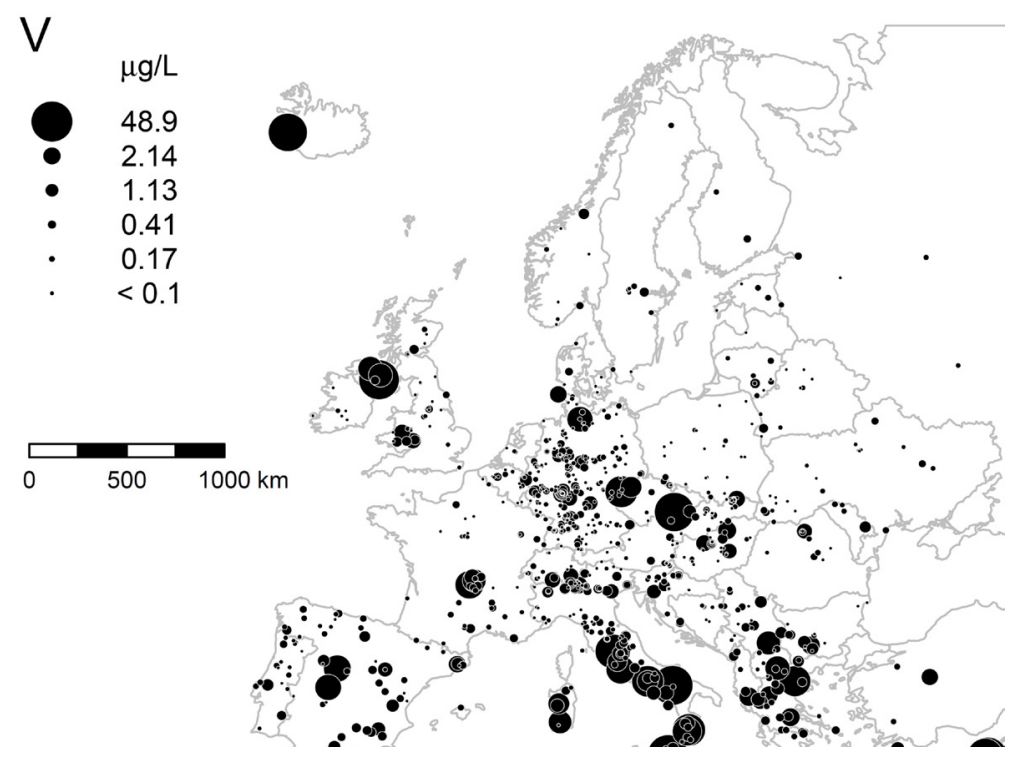

Fig. 17. Distribution of vanadium (V) in European bottled water samples (from Reimann and Birke 2010, p.189).

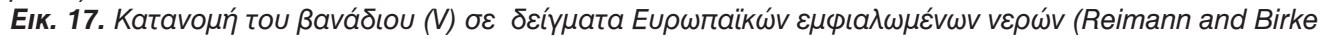

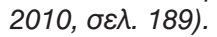

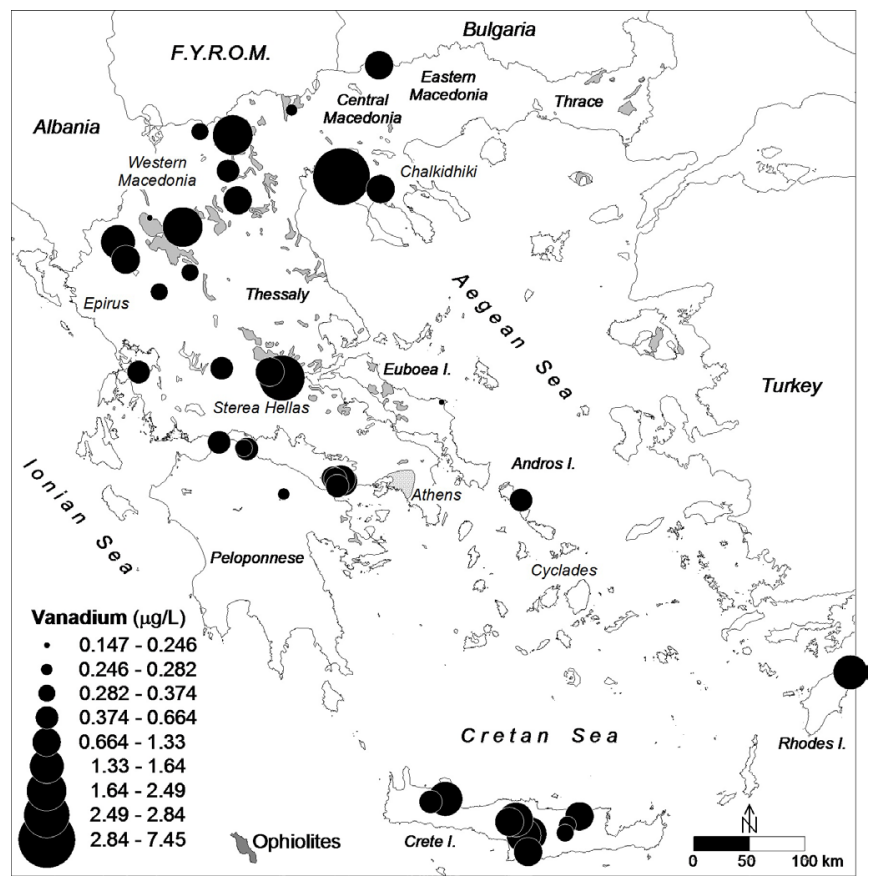

Fig. 18. Distribution of vanadium (V) in Hellenic bottled water samples (see also Fig. 1 and Tab. 1 for sample location numbers and brand names, respectively).

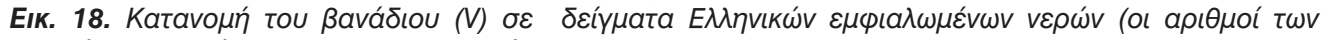

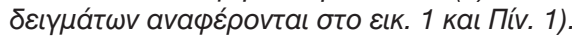


In Hellas, the elevated $\mathrm{V}$ values in the bottled waters of Ydor Sourotis-31 at $7.45 \mu \mathrm{g} / \mathrm{L}$ (Central Macedonia northern Hellas), loli-4 at $2.72 \mu \mathrm{g} / \mathrm{L}$ (Fthiotidha, central Hellas), Pindos-8 at $2.48 \mu \mathrm{g} / \mathrm{L}$ (Grevena, Western Macedonia), and Drossia-49 at $1.94 \mu \mathrm{g} / \mathrm{L}$ (Edessa, Western Macedonia) are all associated directly or indirectly with ophiolites (Fig. 17).

Bottle material leaching can have an impact on the observed $\mathrm{V}$ concentrations of water sold in both, glass and PET bottles (up to $0.06 \mu \mathrm{g} / \mathrm{L}$ ). At low $\mathrm{pH}$ bottle leaching is increased (up to $0.08 \mu \mathrm{g} / \mathrm{L} \mathrm{V}$ ). No drinking water standard is defined for $\mathrm{V}$ by the European Union. Bosnia and Herzegovina, Croatia and F.Y.R.O.M. have set a limit of $5 \mu \mathrm{g} / \mathrm{L} V$ for drinking water, and Serbia $1 \mu \mathrm{g} / \mathrm{L}$, whereas Ukraine has defined a limit of $100 \mu \mathrm{g} / \mathrm{L} \mathrm{V}$ (Reimann and Birke, 2010).

Although vanadium can be biologically active, and is an essential nutrient for several micro-organisms and animals, its role in the human body is unclear and remains controversial.

\subsubsection{Uranium distribution}

Uranium in European bottled water varies from $<0.001$ to $229 \mu \mathrm{g} / \mathrm{L}(\mathrm{n}=884)$, with a median of $0.228 \mu \mathrm{g} / \mathrm{L}$ (Table 3; Reimann and Birke 2010), and in European surface water, $U$ has a narrower range from $<0.002$ to $21.4 \mu \mathrm{g} / \mathrm{L}(\mathrm{n}=807)$, but a slightly higher median of $0.32 \mu \mathrm{g} / \mathrm{L}$ (Salminen et al., 2005).

According to Hem (1992), a typical concentration of $U$ in surface water has been estimated to be in the range of $0.1-10$ $\mu \mathrm{g} / \mathrm{L}$. Uranium in Hellenic bottle water varies from $<0.001$ to $10 \mu \mathrm{g} / \mathrm{L}(\mathrm{n}=41)$, with a median of $0.307 \mu \mathrm{g} / \mathrm{L}$ (Salminen et al., 2005), and the Hellenic surface water has a wider range from 0.08 to $20.50(n=27)$, with a slightly higher median at $0.41 \mu \mathrm{g} / \mathrm{L}$. The $U$ distribution map in bottled water is rather noisy (Fig. 19). The median levels in southern Europe are enhanced when compared to northern Europe.

A similar trend exists in European surface water (Salminen et al., 2005). High values can often be traced to wells in granitic bedrock (e.g., Sardinia, Sweden, Finland) or to wells in sandstone (Bunter and Keuper in central England and central Europe, respectively). The constructed histogram and density trace (see Reimann and Birke, 2010) suggest that many samples at the higher end of the distribution (above $1 \mu \mathrm{g} / \mathrm{L} \mathrm{U}$ ) were diluted and that the map may, thus, not necessarily represent the natural $U$ distribution in ground water. The highest value $(229 \mu \mathrm{g} / \mathrm{L})$ was observed in a bottled water from the Czech Republic. There are, however, reports on single water wells delivering water with considerably higher $U$ values $(2 \mathrm{mg} / \mathrm{L}$ from a well in Norway- see Reimann et al., 1996, and $14 \mathrm{mg} / \mathrm{L}$ from Finland - see Asikainen and Kahlos, 1979).

The four highest $U$ values in Hellenic bottled water are Vitsi-48 (10 $\mu \mathrm{g} / \mathrm{L})$, Beles-46 (2.8 $\mu \mathrm{g} / \mathrm{L})$, Drosoula-10 (1.5 $\mathrm{\mu g} / \mathrm{L})$ and Athos or Iro-33 $(1.47 \mu \mathrm{g} / \mathrm{L})$ are near to granitic masses (Fig. 20).

Bottle material leaching can have a minor influence on the $U$ distribution observed in water sold in glass bottles, especially at a low $\mathrm{pH}$, where the maximum value leaching from a glass bottle was $0.1 \mu \mathrm{g} / \mathrm{L}$. However, even from soft PET bottles up to $0.06 \mu \mathrm{g} / \mathrm{L} U$ was observed leaching.

A drinking water standard for $U$ is under discussion in the European Union: currently, a limit of $15 \mu \mathrm{g} / \mathrm{L} \mathrm{U}$ appears probable. The U.S. Environmental Protection Agency has defined a drinking water limit of $30 \mu \mathrm{g} / \mathrm{L}$. In Germany, an upper limit of $2 \mu \mathrm{g} / \mathrm{L} U$ has been defined for bottled water used to prepare baby food and 10 $\mu \mathrm{g} / \mathrm{L}$ for drinking water. 


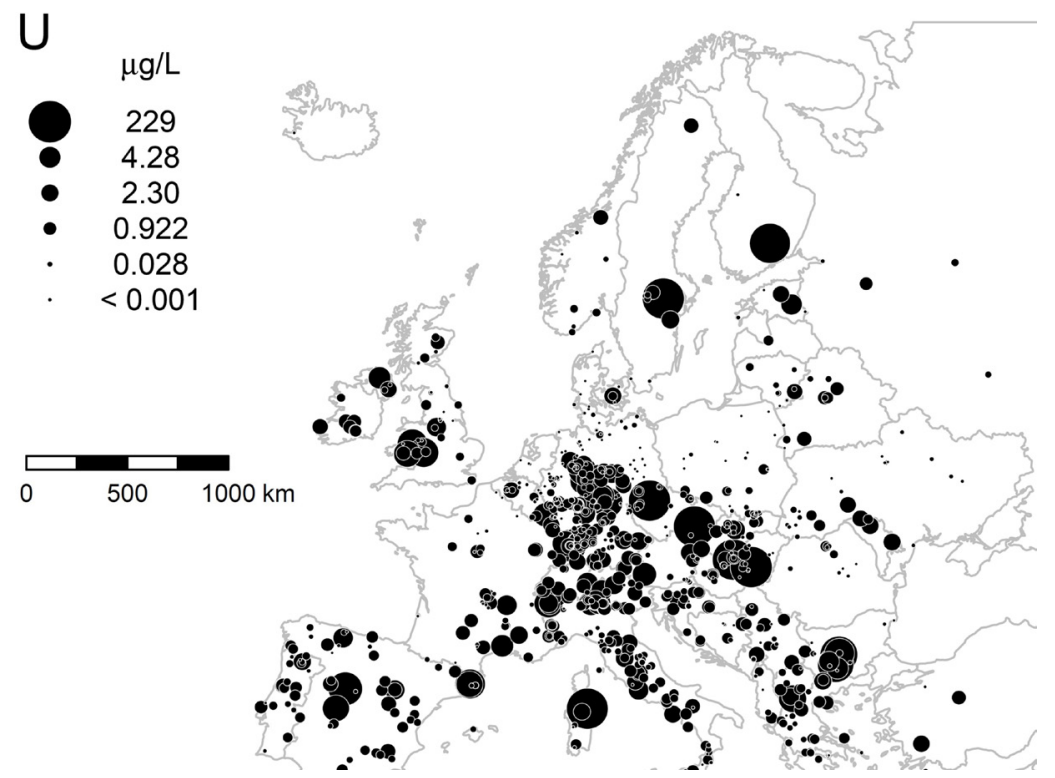

Fig. 19. Distribution of uranium (U) in European bottled water samples (from Reimann and Birke, 2010, p.187).

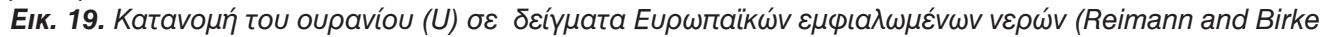

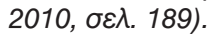

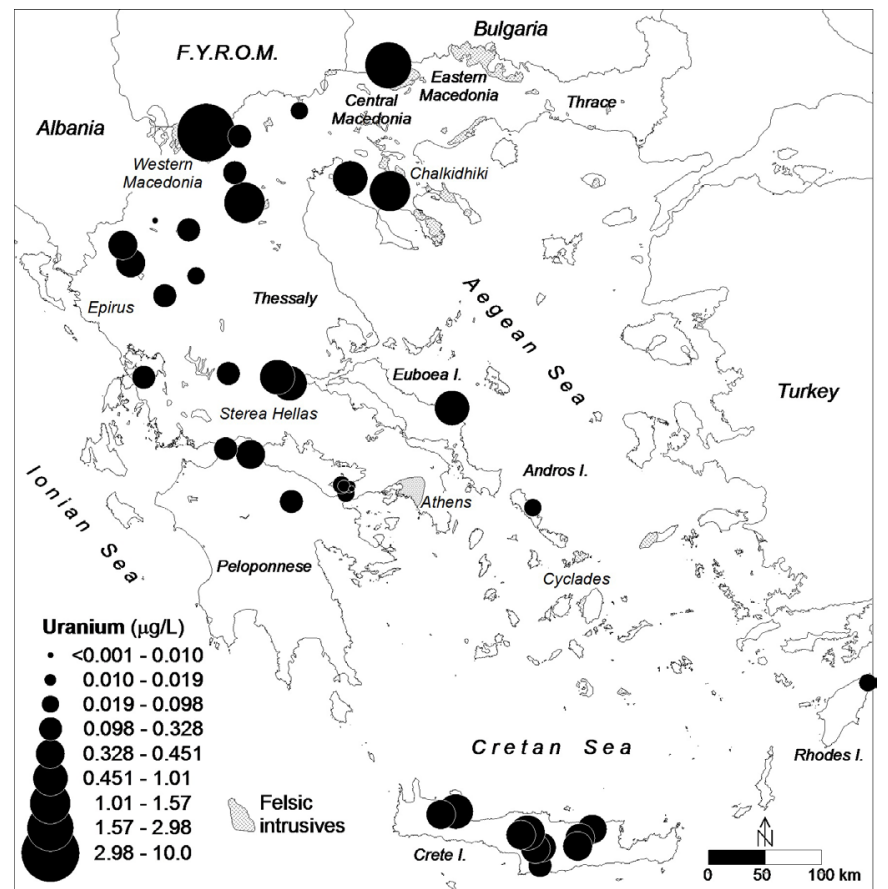

Fig. 20. Distribution of uranium (U) in Hellenic bottled water samples 962 (see also Fig. 1 and Tab. 1 for sample location numbers and brand names, respectively).

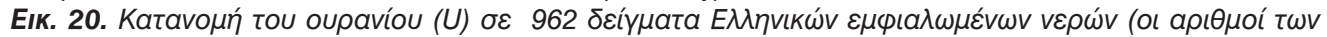

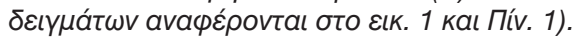


Russia has defined a limit of $1.8 \mu \mathrm{g} / \mathrm{L} \mathrm{U}$ for mineral water (see Appendix A in Reimann and Birke, 2010). Seven samples of the European bottled water data set returned values above $30 \mu \mathrm{g} / \mathrm{L}$, twelve samples exceed $15 \mu \mathrm{g} / \mathrm{L}$ and $107 \mathrm{sam}$ ples are above $2 \mu \mathrm{g} / \mathrm{L}$.

\section{Discussion and Conclusions}

Geology is one of the key factors influencing the observed European and, of course, Hellenic, element concentrations in bottled water samples for a significant number of elements. Examples include the high values of $\mathrm{Cr}$, clearly related to mafic-ultramafic rocks (ophiolites), $\mathrm{V}$ indicates the presence of recent and active volcanism in Europe and ophiolites in Hellas, $U$ is associated with granitic intrusions and Keuper and Bunter sandstone, and $\mathrm{Mg} / \mathrm{Ca}$ ratios are associated with ophiolites, dolomite and dolomitic limestone in Hellas.

The processes contributing to the concentration of major ions in ground water depend on carbonate dissolution and precipitation, cation exchange, concentration of evaporitic salts disseminated throughout marine deposited sedimentary rocks, and in some cases to dissolution of aluminosilicate minerals. Although gypsum and anhydrite occur in many parts of Hellas, the bottled water samples are undersaturated with respect to gypsum and, therefore, it is not considered to be an important control on the concentrations of $\mathrm{Ca}^{2+}$ and $\mathrm{SO}_{4}{ }^{2-}$ in the aquifer source rocks of these waters, or the formations through which ground water passes.

The Hellenic bottled water samples are classified in the $\mathrm{Ca}^{2+}-\mathrm{Mg}^{2+}-\mathrm{HCO}_{3}-$ hydrochemical facies of the Chadha diagram (Chadha, 1999), and this is due to the lithology, which is dominated by dolomitic limestone, limestone, marble, and mafic-ultramafic rocks (ophiolites). Similarly, the dominant cations and anions are respectively $\left(\mathrm{Ca}^{2+}+\mathrm{Mg}^{2+}\right)$ and $\left(\mathrm{HCO}_{3}\right.$ - and $\left.\mathrm{CO}_{3}{ }^{2-}\right)$.

The source aquifers of Hellenic bottled water are apparently continuously replenished by fresh water. A conclusion, which is supported by TDS, alkalinity, $\left(\mathrm{Ca}^{2+}+\mathrm{Mg}^{2+}\right) /\left(\mathrm{K}^{+}+\mathrm{Na}^{+}\right)$and $\mathrm{Na}^{+} / \mathrm{K}^{+}$ ratios, and the $\mathrm{NO}_{3}$ - versus $\mathrm{Cl}$ biplot.

The $\mathrm{Cl} / \mathrm{Br}$ ratios, together with $\mathrm{Cl}$ / $\sum$ anion ratios, and $\mathrm{Na}^{+} /\left(\mathrm{Na}^{+}+\mathrm{Cl}^{-}\right)$ratios support isotopic data (E. Dotsika, person. commun., 2010) that the source aquifers of Hellenic bottled water are not affected by sea water intrusion, even at sites near the coast. The concentrations of $\mathrm{Na}^{+}$and $\mathrm{Cl}$ ions mainly originate from the dissolution of evaporitic salts within the aquifer host rocks, or from the rock formations through which ground water percolates. Water-rock interactions are supported by the $\left(\mathrm{Na}^{+}-\mathrm{Cl}\right)$ versus $\left(\mathrm{Ca}^{2+}\right.$ $\left.+\mathrm{Mg}^{2+}-\mathrm{SO}_{4}{ }^{2-}-\mathrm{HCO}_{3}-\right)$ and $\mathrm{B}^{3+}$ versus $\mathrm{Cl}$ - biplots.

Finally, the chemical composition of source aquifers of the studied bottled water samples appears to be comparatively stable over time, since there is in fact a good correlation between the results of this study and those displayed on bottle labels going back to 1998 (Demetriades, 2010a; Reimann and Birke, 2010). Stable chemistry of source aquifers is, in fact, a requirement in the Natural Mineral Waters Directive (EU, 2009; Annex I, I.3, p.51), i.e., "The composition, temperature and other essential characteristics of natural mineral water shall remain stable within the limits of natural fluctuation; in particular, they shall not be affected by possible variations in the rate of flow". The data presented in the published geochemical atlas (Reimann and Birke 2010) can, therefore, be used to gain a first impression of the natural variation 
of analysed elements in ground water at a European scale. Natural variation is enormous, usually spanning three to four and, occasionally, up to seven orders of magnitude.

Several elements, where no potable water standards are defined in Europe, show surprisingly high concentrations in bottled water. In terms of health effects, more attention at both ends of the concentration range (deficiency as well as toxicity) may be required for quite a number of elements.

For some elements the reported concentrations can be influenced by bottle material. However, only for Sb was bottle leaching, in comparison to its natural concentrations in water, so serious that the results could not be used to plot a distribution map or taken to represent its natural concentration and variation in Europe. In general, glass bottles leach more elements to the stored water than PET bottles. However, all values, observed during the leaching tests, were well below all maximum admissible concentrations (MAC), as defined for drinking water in Europe, and it can, thus, be tentatively concluded that bottle leaching is unlikely to represent a health risk. The bottle leaching test demonstrated that there exist bottles that do not leach any of the indicated elements to the stored water.

In terms of water standards, the majority of samples fulfil the requirements of the European Union legislation for mineral (and drinking) water. For some elements, a few bottled water samples exceed the potable water standards, e.g., the maximum values observed for Al, As, $\mathrm{Ba}, \mathrm{F}^{-}, \mathrm{Mn}, \mathrm{Ni}, \mathrm{NO}_{2^{-}}, \mathrm{NO}_{3^{-}}$, Se and $\mathrm{U}$. It must be noted that the maximum admissible concentration for $\mathrm{F}^{-}$in bottled mineral water is set very high $(5 \mathrm{mg} / \mathrm{L}$ instead of the $1.5 \mathrm{mg} / \mathrm{L}$ valid for drink- ing water) in order to avoid too many compliance failures, i.e., about $5 \%$ of all mineral water samples report F- concentrations above $1.5 \mathrm{mg} / \mathrm{L}$. This statutory practice is questionable in view of bottled water increasingly replacing tap water as general drinking water. With very few exceptions (Al, As, B, Ba, Fe, $\mathrm{Mn}, \mathrm{Ni}$, and $\mathrm{Se}$ - Demetriades 2010a), all values reported in the study of European ground water geochemistry, using bottled water as sampling medium are, however, well below the MAC values as defined by European legislation.

It can be concluded that the idea of using bottled water as a first proxy for ground water geochemistry and quality at the European scale was not as absurd as it might, at first glance, have appeared. Despite all potential problems, it has been shown that natural variation in ground water quality is much larger than the impact of any secondary consideration. Thus, on most element distribution maps, the importance of geology and other natural processes on the chemical composition of ground water is clearly visible.

\section{Acknowledgements}

Without the dedicated input of all members of the EuroGeoSurveys Geochemistry EGG Team and associated friends and colleagues this project would have not been possible. Thanks are due to Adriana Ion (Geological Institute of Romania); Aivars Gilucis (Latvian Environment, Geology and Meteorology Agency); Benedetto De Vivo, Annamaria Lima and Stefano Albanese (University of Napoli Federico II, Italy); Bjørn Frengstad, Rolf Tore Ottesen and Ola Eggen (Geological Survey of Norway); Børge Johannes Wigum (Mannvit hf, Iceland); Boris I. Malyuk, Volodymyr Klos and Maryna Vladymyrova, (Geological Sur- 
vey of Ukraine); Carla Lourenço and Maria Joao Batista (Laboratório Nacional de Energia e Geologia, Portugal); Corina lonesco (University of Cluj-Napoca, Romania); David Banks (Holymoor Consultancy Ltd., U.K.); Dee Flight, Shaun Reeder and Pauline Smedley (British Geological Survey); Domenico Cicchella (University of Sannio, Italy); Edith Haslinger (Austrian Institute of Technology); Enrico Dinelli (University of Bologna, Italy); Friedrich Koller (University of Vienna); Gerhard Hobiger and Albert Schedl (Geological Survey of Austria); Gyozo Jordan, Ubul Fugedi and Laszlo Kuti (Geological Institute of Hungary); Hazim Hrvatovic, Neven Miosic, Ferid Skopljak and Natalija Samardzic (Geological Survey of the Federation of Bosnia and Herzegovina); Ignace Salpeteur and Christophe Innocent (BRGM, France); Ilse Schoeters (Rio Tinto Minerals); Jaan Kivisilla and Valter Petersell (Geological Survey of Estonia); Josip Halamić and Ajka Šorša (Croatian Geological Survey); Juan Locutura, Alejandro Bel-lan and Mar Corral (Instituto Geologico y Minero de Espana); Kaj Lax and Madelen Andersson (Geological Survey of Sweden); Kujtim Onuzi (Institute of Geoscience, Technical University of Tirana); Lech Smietanski (Polish Geological Institute); Liida Bityukova (Institute of Geology at Tallinn University of Technology, Estonia); Maria Titovet (Ministry for Ecology and Nature of Republic Moldova, Department of Hydrogeology); Marianthi Stefouli, Panagiotis Sampatakakis, Constantinos Nikas, Athanasios Hatzikirkou, Eleftheria Poyiadji, Natalia Spanou, Georgios Vrachatis, Dimitris Dimitriou, Michalis Vavrados, Evangelos Nicolaou and Pavlos Vekios (Institute of Geology and Mineral Exploration, Hellas); Mateja Gosar (Geological Survey of Slovenia); Milena Zlokolica-Mandic, Tanja Petrovic and Aleksandra Gulan
(Geological Institute of Serbia); Miloslav Duris (Czech Geological Survey); Nebojsa Veljkovic (Serbian Environmental Protection Agency); Neda Devic (Geological Survey of Montenegro); Nikolay Phillipov (SC Mineral, Russia); Olga Karnachuk (Tomsk State University, Russia); Paolo Valera (University of Cagliari, Italy); Peter Filzmoser (Institute of Statistics and Probability Theory, Vienna University of Technology); Peter Hayoz (Federal Office of Topography, Swiss Geological Survey); Peter Malik (State Geological Institute of Dionyz Stur, Slovakia); Raymond Flynn (Queen's University Belfast, Northern Ireland); Reijo Salminen, Timo Tarvainen and Jaana Jarva (Geological Survey of Finland); Robert Maquil (Service Géologique du Luxembourg); Trajce Stafilov (Sts. Cyril and Methodius University, Skopje, F.Y.R.O.M.), Uwe Rauch, Lars Kaste, Hans Lorenz and Fabian Jähne (Federal Institute for Geosciences and Natural Resources, Germany); Valeri Trendavilov (Department of Geology and Permits for Exploration, Subsurface and Underground Resources Office, Ministry of Environment and Water, Bulgaria); Virgilija Gregorauskiene (Lithuanian Geological Survey), and Walter De Vos (Geological Survey of Belgium). The members of the laboratory staff of BGR (Hans Lorenz, Wolfgang Glatte, Bodo Harazim, Fred Flohr, Anna Degtjarev, Jürgen Rausch) are thanked for their dedicated work on the analysis of the bottled water samples. Finally, we would like to thank the Director of NGU, Dr. Morten Smelror, and the President of BGR, Professor Hans-Joachim Kümpel for their support of the project.

\section{References}

Aitchison, J., 1986. The Statistical Analysis of Compositional data. Chapmann and Hall, London, U.K., 416 pp. 
Aitchison, J., 2003. The Statistical Analysis of Compositional data. Reprint. Blackburn Press, Caldwell, N.J., U.S.A., 416 pp.

Ander, E.L., Smith, B., Reeder, S., 2006. Thematic interpretation of stream water chemistry. In: De Vos, W., Tarvainen, T. (Chief Eds.) Salminen, R., Reeder, S., De Vivo, B., Demetriades, A., Pirc, S., Batista, M.J., Marsina, K., Ottesen, R.-T., O'Connor, P.J., Bidovec, M., Lima, A., Siewers, U., Smith, B., Taylor, H., Shaw, R., Salpeteur, I., Gregorauskiene, V., Halamic, J., Slaninka, I., Lax, K., Gravesen, P., Birke, M., Breward, N., Ander, E.L., Jordan, G., Duris, M., Klein, P., Locutura, J., Bel-lan, A., Pasieczna, A., Lis, J., Mazreku, A., Gilucis, A., Heitzmann, P., Klaver, G. and Perersell, V., Geochemical Atlas of Europe - Part 2: Interpretation of geochemical maps, additional tables, figures, maps and related publications. Geological Survey of Finland, Espoo, 455-488 - URL: http:// www.gtk.fi/publ/foregsatlas/ (Last accessed on 2/2/2012).

Asikainen, M., Kahlos, H., 1979. Anomalously high concentrations of uranium, radium and radon in water from drilled wells in the Helsinki region. Geochimica et Cosmochim Acta 4, 1681-1686.

Belkhiri, L., Boudoukha, A., Mouni, L., 2010. Groundwater quality and its suitability for drinking and agricultural use in Ain Azel plain, Algeria. Journal of Geography and Regional Planning 3(6), 151-157.

Birke, M., Demetriades, A., De Vivo, B. (Eds.), (2010a), Mineral Waters of Europe. Special Issue, Journal of Geochemical Exploration 107(3), 217422.

Birke, M., Reimann, C., Demetriades,
A., Rauch, U., Lorenz, H., Harazim, B., Glatte, W., 2010. Determination of major and trace elements in European bottled mineral water - Analytical methods. In: Birke, M. Demetriades, A., De Vivo, B., (Guest Eds.), Mineral Waters of Europe. Special Issue, Journal of Geochemical Exploration 107(3), 217-226.

Birke, M., Rauch, U., Harazim, B., Lorenz, H., Glatte, W., 2010c. Major and trace elements in German bottled water, their regional distribution, and accordance with national and international standards. In: Birke, M. Demetriades, A., De Vivo, B., (Guest Eds.), Mineral Waters of Europe. Special Issue, Journal of Geochemical Exploration 107(3), 245-271.

Birke, M., Rauch, U., Lorenz, H., Kringel, R., 2010d. Distribution of uranium in German bottled and tap water. In: Birke, M. Demetriades, A., De Vivo, B., (Guest Eds.), Mineral Waters of Europe. Special Issue, Journal of Geochemical Exploration 107(3), 272-282.

Bityukova, L., Petersell, V., 2010. Chemical composition of bottled mineral waters in Estonia. In: Birke, M. Demetriades, A., De Vivo, B., (Guest Eds.), Mineral Waters of Europe. Special Issue, Journal of Geochemical Exploration 107(3), 238-244.

Björklund, A., Gustavsson, N., (1987), Visualization of geochemical data on maps: New options. Journal of Geochemical Exploration 29, 89-103.

Bodiš, D., Božíková, J., Liščák, P., Malík, P., Panák, D., Slaninka, I., Kordík, J., Marcin, D., 2010. Mineral waters in Slovakia - Evaluation of chemical composition stability using both historical records and the most recent data. In: Birke, M. Demetriades, A., De Vivo, B., (Guest Eds.), Miner- 
al Waters of Europe. Special Issue, Journal of Geochemical Exploration 107(3), 382-390.

Bornovas, J., Rondogianni-Tsiambaou, Th., 1983. The geological map of Greece 1:500,000. Institute of Geology and Mineral Exploration, Athens, Hellas.

Brenčič, M., Vreča, P., 2010. The use of a finite mixture distribution model in bottled water characterisation and authentication with stable hydrogen, oxygen and carbon isotopes - Case study from Slovenia. In: Birke, M. Demetriades, A., De Vivo, B., (Guest Eds.), Mineral Waters of Europe. Special Issue, Journal of Geochemical Exploration 107(3), 391-399.

Brenčič, M., Ferjan, T., Gosar, M., 2010. Geochemical survey of Slovenian bottled waters. In: Birke, M. Demetriades, A., De Vivo, B., (Guest Eds.), Mineral Waters of Europe. Special Issue, Journal of Geochemical Exploration 107(3), 400-409.

Chadha, D.K., 1999. A proposed new diagram for geochemical classification of natural waters and interpretation of chemical data. Hydrogeological Journal 7(5), 431-439.

Cicchella, D., Albanese, S., De Vivo, B., Dinelli, E., Giaccio, L., Lima, A. \& Valera, P., 2010. Trace elements and ions in Italian bottled mineral waters: Identification of anomalous values and human health related effects. In: Birke, M. Demetriades, A., De Vivo, B., (Guest Eds.), Mineral Waters of Europe. Special Issue, Journal of Geochemical Exploration 107(3), 336349.

CRAN, 2012. The comprehensive $\mathrm{R}$ archive networm. Intitute for Statistics and Mathematics, WU Wien. http:// cran.r-project.org (Last accessed on 2/2/2012).
Demetriades, A., 2010a. General ground water geochemistry of Hellas using bottled water samples. In: Birke, M. Demetriades, A., De Vivo, B., (Guest Eds.), Mineral Waters of Europe. Special Issue, Journal of Geochemical Exploration 107(3), 283-298.

Demetriades, A., 2010b. Use of measurement uncertainty in a probabilistic scheme to assess compliance of bottled water with drinking water standards. In: Birke, M. Demetriades, A., De Vivo, B., (Guest Eds.), Mineral Waters of Europe. Special Issue, Journal of Geochemical Exploration 107(3), 410-422.

Demetriades, A., Reimann, C, Birke, M., The Eurogeosurveys Geochemistry EGG Team, 2012. European Ground Water Geochemistry Using Bottled Water as a Sampling Medium. Chapter 10. In: Quercia, F.F., Vidojevic, D. (Eds.), Clean Soil and Safe Water. NATO Science for Peace and Security Series C: Environmental Security. Springer, Dordrecht, 115-139.

Dinelli, E., Lima, A., De Vivo, B., Albanese, S., Cicchella, D., Valera, P., 2010. Hydrogeochemical analysis on Italian bottled mineral waters: Effects of geology. In: Birke, M. Demetriades, A., De Vivo, B., (Guest Eds.), Mineral Waters of Europe. Special Issue, Journal of Geochemical Exploration 107(3), 317-335.

Dotsika, E., Poutoukis, D., Raco, B., Psomiadis, D., 2010. Stable isotope composition of Hellenic bottled waters. In: Birke, M. Demetriades, A., De Vivo, B., (Guest Eds.), Mineral Waters of Europe. Special Issue, Journal of Geochemical Exploration 107(3), 299-304.

De Vivo, B., Birke, M., Cicchella, D., Giaccio, L., Dinelli, E., Lima, A., Albanese, S., Valera, P., 2010. Acqua di 
casa nostra. Le Scienze 508, 76-85.

De Vos, W., Tarvainen, T. (Chief Eds.), Salminen, R., Reeder, S., De Vivo. B., Demetriades, A., Pirc, S., Batista, M.J., Marsina, K., Ottesen, R.T., O'Connor, P.J., Bidovec, M., Lima, A., Siewers, U., Smith, B., Taylor, H., Shaw, R., Salpeteur, I., Gregorauskiene, V., Halamic, J., Slaninka, I., Lax, K., Gravesen, P., Birke, M., Breward, N., Ander, E.L., Jordan, G., Duris, M., Klein, P., Locutura, J., Bel-lan, A., Pasieczna, A., Lis, J., Mazreku, A., Gilucis, A., Heitzmann, P., Klaver, G., and Petersell, V., 2006. Geochemical Atlas of Europe. Part 2 - Interpretation of geochemical maps, Additional Tables, Figures, Maps and related publications. Geological Survey of Finland, Espoo, Finland, 692 pp. Available online at: http://www.gtk.fi/ publ/foregsatlas/ (Last accessed on 2/2/2012).

Durov, S.A., 1948. Natural waters and graphic representation of their compositions. Akademiya Nauk SSSR Doklady 59, 87-90.

Ellis, A.J., Mahon, W.A.J., 1977. Chemistry and geothermal systems. Academic Press, New York, 392 pp.

EU, 1998. EU directive 98/83/EC of 3 November 1998 on the quality of water intended for human consumption. Official Journal of the European Communties, 05/12/1998 L330, 32-54.

EU, 2003. EU directive 2003/40/EC of 16 May 2003 establishing the list, concentration limits and labelling requirements for the constituents of natural mineral waters and the conditions for using ozone-enriched air for the treatment of natural mineral waters and spring waters. Official Journal of the European Union, 22/5/2003 L126, 34-39.

EU, 2009. EU directive 2009/54/EC of the European Parliament and of the Council of 18 June 2009 on the exploitation and marketing of natural mineral waters. Official Journal of the European Union, 26/6/2009 L164, 45-58.

Filzmoser, P., Hron, K., Reimann, C., 2009. Univariate statistical analysis of environmental (compositional) data Problems and possibilities. Science of the Total Environment 407, 61006108.

Fotiou, E., Kolovos, N., 2004. Evaluation of bottled water quality. Bulletin of the Geological Society of Greece XXXVI, 2087-2093.

Frengstad, B.S., Lax, K., Tarvainen, T., Jæger, Ø., Wigum, B.J., 2010. The chemistry of bottled mineral and spring waters from Norway, Sweden, Finland and Iceland. In: Birke, M. Demetriades, A., De Vivo, B., (Guest Eds.), Mineral Waters of Europe. Special Issue, Journal of Geochemical Exploration 107(3), 350-361.

Fugedi, U., Kuti, L., Jordan, G., Kerek, B., 2010. Investigation of the hydrogeochemistry of some bottled mineral waters in Hungary. In: Birke, M. Demetriades, A., De Vivo, B., (Guest Eds.), Mineral Waters of Europe. Special Issue, Journal of Geochemical Exploration, 107(3), 305-316.

Gustavsson, N., Lampio, E., Tarvainen, T., 1997. Visualization of geochemical data on maps at the Geological Survey of Finland. Journal of Geochemical Exploration 59, 197-207.

Hall, G.E.M., 1998, Relative contamination levels observed in different types of bottles used to collect water samples. Explore, 101, 3-7.

Hatzianastassiou, N., Katsoulis, B., Pnevmatikos, J., Antakis, V., 2008. Spatial and Temporal Variation of Precipitation in Greece and Surrounding Re- 
gions Based on Global Precipitation Climatology Project Data. Journal of Climate, 21(6), 1349-1370.

Hem, J.D., 1970. Study and interpretation of the chemical characteristics of natural water. United States Geological Survey Water Supply Paper 1473, Second Edition, 363 pp.

Houslow, A.W., 1995. Water quality data analysis and interpretation. Lewis Publishers, Boca Raton, FL, 397 pp.

Jankowski, J., Acworth, R.I., Shekarforoush, S., 1998. Reverse ion exchange in a deeply weathered porphyritic dacite fractured aquifer system, Yass, New South Wales, Australia. In: Aehart, G.B., Hultson, J.R. (Eds), Proceedings of 9th International Symposium of Water- Rock Interaction, Taupo, New Zealand, 30 March-3 April 1998. Balkema, Rotterdam, 243-246.

Kallergis, G., 2000. Applied environmental hydrogeology, Volume $B^{\prime}$ Environmental hydrogeology. Technical Chamber of Greece, Athens, 345 pp. (in Greek).

Kanellopoulou, E.A., 2002. Spatial distribution of rainfall seasonality in Greece. Weather, 57(6), 215-219.

Keresztes, S., Tatar, E., Mihucz, V.G., Virag, I., Majdik, C., Zaray, G., 2009. Leaching of antimony from polyethylene terephthalate (PET) bottles into mineral water. Science of the Total Environment, 407, 4731-4735.

Kortatsi, B.K., 2006. Hydrochemical characterisation of groundwater in the Accra plains of Ghana. Environmental Geology 50, 299-311.

Krachler, M., Shotyk, W., 2009. Trace and ultratrace metals in bottled waters: Survey of sources worldwide and comparison with refillable metal bottles. Science of the Total Environment, 407, 1089-1096.
Lambrakis, N., Kallergis, G., 2005. Contribution to the study of Greek thermal springs: hydrogeological and hydrochemical characteristics and origin of thermal waters. Hydrogeology Journal, 13, 506-521.

Lima, A., Cicchella, D., Giaccio, L., Dinelli, E., Albanese, S., Valera, P., De Vivo B., 2010. Che acqua beviamo. Le Scienze, 501, 68-77.

Livada, I., Charalambous, G., Assimakopoulos M.N., 2008. Spatial and temporal study of precipitation characteristics over Greece. Theoretical and Applied Climatology, 93(1-2), 45-55.

Lloyd, J.W., 1965. The hydrochemistry of the aquifers of northeastern Jordan. Journal of Hydrology, 3, 319330.

Lloyd, J.W., Heathcote, J.A., 1985. Natural inorganic hydrochemistry in relation to groundwater. Oxford Scientific Publications, Oxford University Press, 296 pp.

Lourenço, C., Luís Ribeiro, L., José Cruz, J., 2010. Classification of natural mineral and spring bottled waters of Portugal using Principal Component Analysis. In: Birke, M. Demetriades, A., De Vivo, B. (Guest Eds.), Mineral Waters of Europe. Special Issue, Journal of Geochemical Exploration 107(3), 362-372.

Maheras, P., Tolika, K., Anagnostopoulou, C., Vafiadis, M., Patrikas, I., Flocas, H., 2004. International Journal of Climatology, 24, 1695-1712.

Mandel, S., Shiftan, Z., 1981. Groundwater resources, investigation and development. Academic Press, N.Y., London, 269 pp.

Mimikou, M.A., 2005. Water resources in Greece: Present and future. Global NEST Journal, 7(3), 313-322.

Misund, A., Frengstad, B., Siewers, U., Reimann, C., 1999. Natural variation 
of 66 elements in European mineral waters. Science of the Total Environment 243/244, 21-41.

Nriagu, J.O., Lawson, G., Wong, H.K.T., Azcue, J.M., 1993. A protocol for minimizing contamination in the analysis of trace metals in Great Lakes waters. Journal of Great Lakes Research 19, 175-182.

Peh, Z., Ajka Šorša, A., Halamić, J., 2010. Composition and variation of major and trace elements in Croatian bottled waters. In: Birke, M. Demetriades, A., De Vivo, B. (Guest Eds.), Mineral Waters of Europe. Special Issue, Journal of Geochemical Exploration, 107(3), 227-237.

Petrović, T., Mandić, M.Z., Veljković, N., Papić, P., Stojković, J., 2012. Geochemistry of Bottled Waters of Serbia. Chapter 19, In: Quercia, F.F., Vidojevic, D. (Eds.), Clean Soil and Safe Water. NATO Science for Peace and Security Series C: Environmental Security. Springer, Dordrecht, 247266.

Petrović, T., Zlokolica, ZlokolicaMandić, M., Veljković, N., Papić, P., Poznanović, M., Stojković, J., Magazinović, S., 2011. Macro and microelements in bottled and tap waters of Serbia. Hemijska industrija. Available online at: http://www.doiserbia.nb.rs/Article. aspx? id =0367598X1100062P (Last accessed on 2/2/2012) .

Petrović, T., Zlokolica-Mandić, M., Veljković, N., Vidojević, D., 2010. Hydrogeological conditions for the forming and quality of mineral waters in Serbia. In: Birke, M. Demetriades, A., De Vivo, B. (Guest Eds.), Mineral Waters of Europe. Special Issue, Journal of Geochemical Exploration 107(3), 373-381.

Piper, A.M., 1944. A graphic procedure in geochemical interpretation of water analyses. American Geophysical Union Transactions 25, 914-923.

Reimann, C., 2005. Geochemical mapping - technique or art? Geochemistry, Exploration, Environment, Analysis 5, 359-370.

Reimann, C., Birke, M. (Eds.), 2010. Geochemistry of European Bottled Water. Borntraeger Science Publishers, Stuttgart, $268 \mathrm{pp}$. Available online at: http://www.schweizerbart.de/publications/detail/artno/001201002 (Last accessed on 2/2/2012).

Reimann, C., Birke, M., Filzmoser, P., 2010a. Bottled drinking water: Water contamination from bottle materials (glass, hard PET, soft PET), the influence of colour and acidification. Applied Geochemistry 25(7), 10301046.

Reimann, C., Birke, M., Filzmoser, P., 2010b. Reply to the comment "Bottled drinking water: Water contamination from bottle materials (glass, hard PET, soft PET), the influence of colour and acidification" by Hayo Müller-Simon. Applied Geochemistry 25(9), 1464-1465.

Reimann, C., Filzmoser, P., Garrett, R.G., Dutter, R., 2008. Statistical data analysis explained - Applied environmental statistics with $R$. Wiley. Chichester, U.K., 343 pp.

Reimann, C., Grimstvedt, A., Frengstad, B., Finne, T.E., 2007. White HDPE bottles as a source of serious contamination of water samples with $\mathrm{Ba}$ and $\mathrm{Zn}$. Science of the Total Environment 374, 292-296.

Reimann, C., Hall, G.E.M., Siewers, U., Bjorvatn, K., Morland, G. Skarphagen, H., Strand, T., 1996. Radon, fluoride and 62 elements as determined by ICP-MS in 145 Norwegian hardrock groundwaters. Science of 
the Total Environment 192, 1-19.

Ross, H.B., 1984. Methodology for the collection and analysis of trace metals in atmospheric precipitation. University of Stockhom, Dept. of Met. Rep. CM-67.

Salminen, R. (Chief Ed.), Batista, M.J., Bidovec, M. Demetriades, A., De Vivo. B., De Vos, W., Duris, M., Gilucis, A., Gregorauskiene, V., Halamic, J., Heitzmann, P., Lima, A., Jordan, G., Klaver, G., Klein, P., Lis, J., Locutura, J., Marsina, K., Mazreku, A., O'Connor, P.J., Olsson, S.Å., Ottesen, R.T., Petersell, V., Plant, J.A., Reeder, S., Salpeteur, I., Sandström, H., Siewers, U., Steenfelt, A., and Tarvainen, T., 2005, Geochemical atlas of Europe. Part 1 - Background information, methodology and maps. Geological Survey of Finland, Espoo, Finland, 526 pp. Available online at: http://www.gtk.fi/publ/foregsatlas/ (Last accessed on 2/2/2012).

Shotyk W., Krachler M., Chen B., 2006. Contamination of Canadian and European bottled waters with antimony leaching from PET containers. Journal of Environmental Monitoring 8, 288-292.

Shotyk, W., Krachler, M., 2007a. Contamination of bottled waters with an- timony leaching from poluethylene Terephthalate (PET) increases upon storage. Environmental Science \& Technology 41, 1560-1563.

Shotyk, W., Krachler, M., 2007b. Lead in bottled water: contamination from glass and comparison with pristine groundwater. Environmental Science \& Technology 41, 3508-3513.

Soulios, G.Ch., 2006. General hydrogeology. Volume 4: (g) Quality of ground water; (h) Contamination-pollution of ground water. University Studio Press, Thessaloniki, Hellas, 233 pp. (in Greek).

Tukey, J.W., 1977. Exploratory data analysis. Addison Wesley, Reading, 688 pp.

Vassiliades, E.A., 2010. Zonation of risk of the landslide phenomena in the Hellenic territory. Development and application of models with geographic information systems. Unpublished Ph.D. Thesis, University of Patras, Geology Department, Patras, Hellas, $206 \mathrm{pp}$.

Westerhoff, P., Prapaipong, P., Shock, E., Hillaireau, A., 2008. Antimony leaching from polyethylene terephthalate (PET) plastic used for bottled drinking water. Water Research 42, 551-556. 